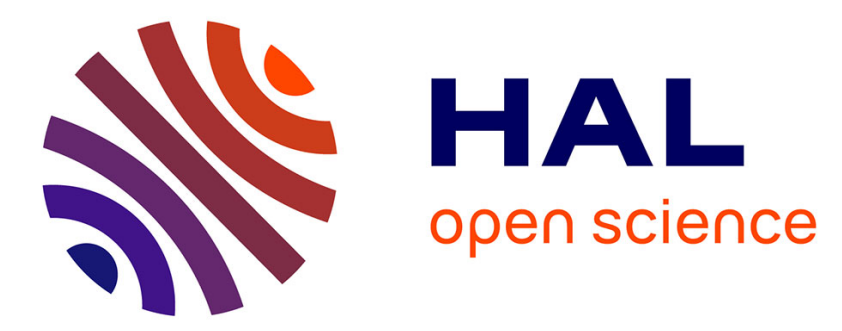

\title{
Restoration of Cenozoic deformation in Asia and the size of Greater India
}

Douwe J.J. van Hinsbergen, Paul Kapp, Guillaume Dupont-Nivet, Peter C. Lippert, Peter G. Decelles, Trond H. Torsvik

\section{> To cite this version:}

Douwe J.J. van Hinsbergen, Paul Kapp, Guillaume Dupont-Nivet, Peter C. Lippert, Peter G. Decelles, et al.. Restoration of Cenozoic deformation in Asia and the size of Greater India. Tectonics, 2011, 30 (5), pp.TC5003. 10.1029/2011TC002908 . insu-00670814

\section{HAL Id: insu-00670814 https://hal-insu.archives-ouvertes.fr/insu-00670814}

Submitted on 29 Jun 2016

HAL is a multi-disciplinary open access archive for the deposit and dissemination of scientific research documents, whether they are published or not. The documents may come from teaching and research institutions in France or abroad, or from public or private research centers.
L'archive ouverte pluridisciplinaire HAL, est destinée au dépôt et à la diffusion de documents scientifiques de niveau recherche, publiés ou non, émanant des établissements d'enseignement et de recherche français ou étrangers, des laboratoires publics ou privés. 


\title{
Restoration of Cenozoic deformation in Asia and the size of Greater India
}

\author{
Douwe J. J. van Hinsbergen, ${ }^{1,2}$ Paul Kapp, ${ }^{3}$ Guillaume Dupont-Nivet, ${ }^{4,5,6}$ \\ Peter C. Lippert, ${ }^{3,7}$ Peter G. DeCelles, ${ }^{3}$ and Trond H. Torsvik ${ }^{1,2,8,9}$ \\ Received 9 March 2011; revised 3 June 2011; accepted 11 July 2011; published 15 September 2011.
}

[1] A long-standing problem in the geological evolution of the India-Asia collision zone is how and where convergence between India and Asia was accommodated since collision. Proposed collision ages vary from 65 to $35 \mathrm{Ma}$, although most data sets are consistent with collision being underway by $50 \mathrm{Ma}$. Plate reconstructions show that since $50 \mathrm{Ma} \sim 2400-3200 \mathrm{~km}$ (west to east) of India-Asia convergence occurred, much more than the 450-900 km of documented Himalayan shortening. Current models therefore suggest that most post-50 Ma convergence was accommodated north of the Indus-Yarlung suture zone. We review kinematic data and construct an updated restoration of Cenozoic Asian deformation to test this assumption. We show that geologic studies have documented $600-750 \mathrm{~km}$ of N-S Cenozoic shortening across, and north of, the Tibetan Plateau. The Pamir-Hindu Kush region accommodated $\sim 1050 \mathrm{~km}$ of N-S convergence. Geological evidence from Tibet is inconsistent with models that propose $750-1250 \mathrm{~km}$ of eastward extrusion of Indochina. Approximately $250 \mathrm{~km}$ of Indochinese extrusion from 30 to $20 \mathrm{Ma}$ of Indochina suggested by SE Asia reconstructions can be reconciled by dextral transpression in eastern Tibet. We use our reconstruction to calculate the required size of Greater India as a function of collision age. Even with a $35 \mathrm{Ma}$ collision age, the size of Greater India is $2-3$ times larger than Himalayan shortening. For a $50 \mathrm{Ma}$ collision, the size of Greater India from west to east is $\sim 1350-2600 \mathrm{~km}$, consistent with robust paleomagnetic data from upper Cretaceous-Paleocene Tethyan Himalayan strata. These estimates for the size of Greater India far exceed documented shortening in the Himalaya. We conclude that most of Greater India was consumed by subduction or underthrusting, without leaving a geological record that has been recognized at the surface.

Citation: van Hinsbergen, D. J. J., P. Kapp, G. Dupont-Nivet, P. C. Lippert, P. G. DeCelles, and T. H. Torsvik (2011), Restoration of Cenozoic deformation in Asia and the size of Greater India, Tectonics, 30, TC5003, doi:10.1029/2011TC002908.

\footnotetext{
${ }^{1}$ Physics of Geological Processes, University of Oslo, Oslo, Norway.

${ }^{2}$ Center for Advanced Study, Norwegian Academy of Science and Letters, Oslo, Norway. USA.

${ }^{3}$ Department of Geosciences, University of Arizona, Tucson, Arizona,

${ }^{4}$ Géosciences Rennes, UMR-CNRS 6118, Université de Rennes 1, Rennes, France.

${ }^{5}$ Paleomagnetic Laboratory 'Fort Hoofddijk', Department of Earth Sciences, University of Utrecht, Utrecht, Netherlands.

${ }^{6}$ Key Laboratory of Orogenic Belts and Crustal Evolution, Ministry of Education, Beijing, China.

${ }^{7}$ Department of Earth and Planetary Sciences, University of California, Santa Cruz, California, USA.

${ }^{8}$ Center for Geodynamics, Geological Survey of Norway, Trondheim, Norway.

${ }^{9}$ School of Geosciences, University of the Witwatersrand, Johannesburg, South Africa.

Copyright 2011 by the American Geophysical Union. 0278-7407/11/2011TC002908
}

\section{Introduction}

[2] Collision between continental lithosphere of the Indian and Asian plates has led to the largest deformed continental region in the world in Cenozoic time. The IndiaAsia orogen includes the Himalaya, the Tibetan Plateau, the Pamir-Hindu Kush, the Tien Shan, Mongolia, and southern Siberia (Figure 1). Effects of the collision range from development of the India-derived Himalayan fold-and-thrust belt in the south [Gansser, 1964; Hodges, 2000], to strikeslip-dominated mountain belts thousands of kilometers to the north in Mongolia and southern Siberia [Molnar and Tapponnier, 1975; Cunningham, 2005; Jolivet et al., 2010; Arzhannikova et al., 2011]. The Indochinese peninsula, to the east of the Himalaya, has been deformed along major strikeslip zones that accommodated southeastward translation of lithosphere, away from the collision zone [Tapponnier et al., 1986]. The amount of southeastward displacement of Indochina is heavily debated in the literature and will be discussed in detail. 


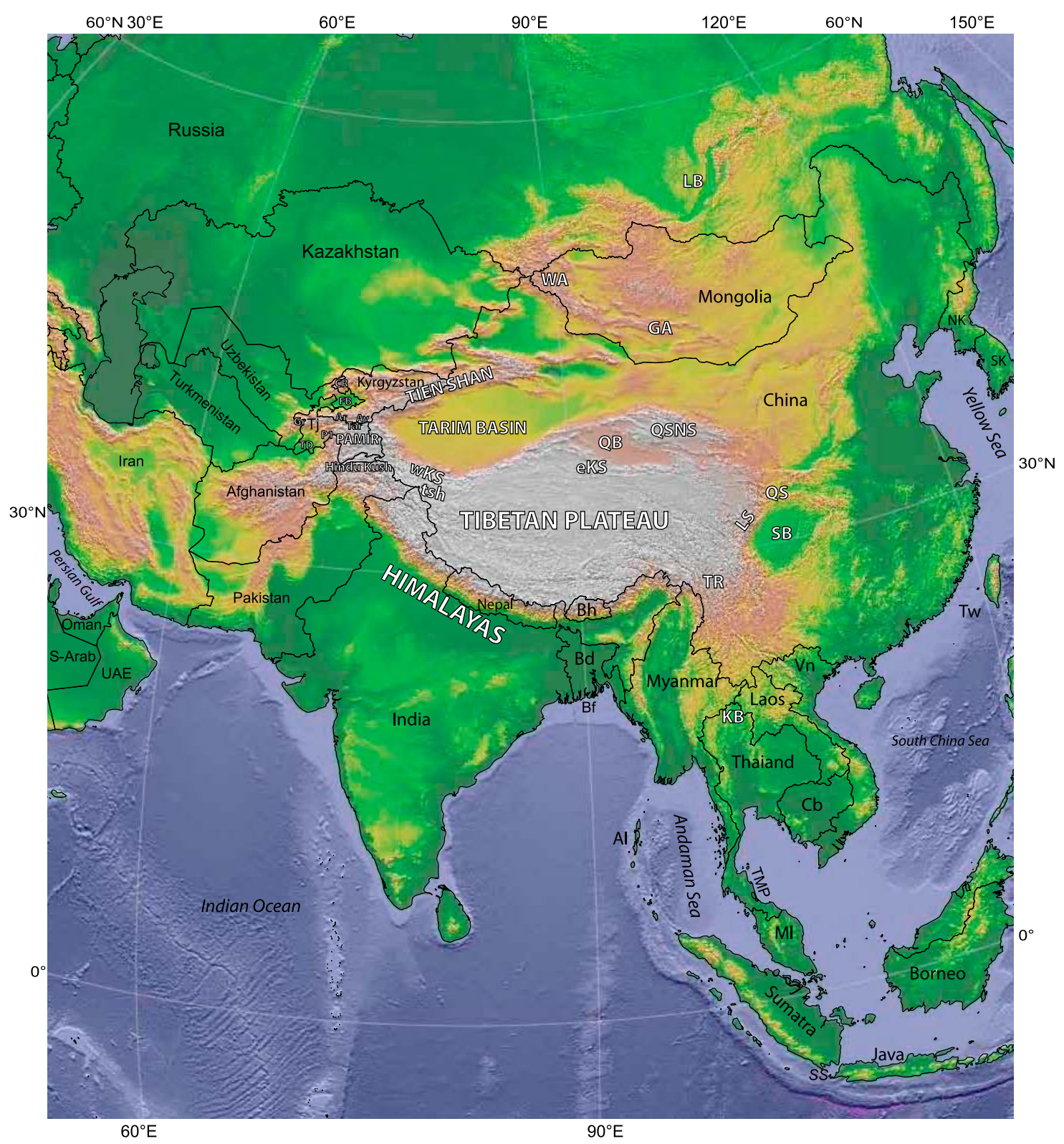

Figure 1. Geographic map (3D Globe projection) of central and eastern Asia. Mountain ranges and major basins. Ai, Andaman Islands; Ar, Alai range; Av, Alai valley; Bd, Bangladesh; Bh, Bhutan; Bf, Bengal fan; Cb, Cambodia; Cr, Chatkal range; eKS, eastern Kunlun Shan; GA, Gobi Altai; Gr, Ghissar range; KB, Khorat basin; LB, Lake Baykal; LS, Longmen Shan; Ml, Malaysia; NK, North Korea; P1, Peter the First range; QB, Qaidam Basin; QS, Qinling Shan; QSNS, Qilian Shan-Nan Shan; S-Arab, Saudi Arabia; SB, Sichuan Basin; SK, South Korea; SS, Sunda Strait; Tar, Trans Alai range; TD, Tadjik Depression; Tj, Tadjikistan; TMP, Thai-Malai peninsula; TR, Three Rivers region; tsh, Tianshuihe; Tw, Taiwan; UAE, United Arab Emirates; Vn, Vietnam; WA, Western Altai; wKS, western Kunlun Shan.

[3] An accurate reconstruction of the kinematic history of the collision zone is essential to assess the dynamics of the India-Asia collision. Boundary conditions for this reconstruction are derived from plate circuits constrained by marine magnetic anomaly and fracture zone-based reconstructions of the Indian and Atlantic oceans; these constrain the relative positions of the Indian and Asian plates through time. The first India-Eurasia plate circuits [Molnar and
Tapponnier, 1975; Patriat and Achache, 1984] have changed by no more than a few hundreds of kilometers over the following decades, despite the publication of new time scales and more detailed marine geophysical data [Torsvik et al., 2008; Molnar and Stock, 2009; Cande et al., 2010; Copley et al., 2010; van Hinsbergen et al., 2011]. These plate circuit models predict $\sim 2400$ and $\sim 3200 \mathrm{~km}$ of convergence between cratonic India and cratonic Asia 
since $50 \mathrm{Ma}$ at the longitudes of the western and eastern Himalayan syntaxes, respectively [van Hinsbergen et al., 2011]. Although these plate circuit estimates are robust, where this convergence was accommodated (south or north of the India-Asia suture), and the type of deformation that accommodated this convergence (thrusting/subduction or strike-slip faulting (extrusion)) remain disputed.

[4] In principle, if all convergence following the initial India-Asia collision was accommodated by crustal shortening (together with delamination and subduction of subcontinental mantle lithosphere [Willett and Beaumont, 1994; Tapponnier et al., 2001; Capitanio et al., 2010]), then we merely need to sum shortening via thrust and strike-slip faulting in Indian and Asian crust. In practice, however, both the age of the India-Asia collision and the magnitude of shortening of Asian and Indian crust are disputed. The map-view area of Asia that was removed by shortening and lateral extrusion after Tethyan Himalaya-Asia collision is defined here as 'Greater Asia', whereas the map-view area of Indian-affinity lithosphere north of the Main Frontal Thrust just prior to the Tethyan Himalaya-Asia collision is referred to as 'Greater India.' Estimates for the age of the collision between the Tethyan Himalaya and southern Tibet range from $\sim 65 \mathrm{Ma}$ [Ding et al., 2005; Cai et al., 2011] to as young as $34 \mathrm{Ma}$ [Aitchison et al., 2007], with most authors preferring an age of 52-50 Ma [e.g., Zhu et al., 2005; Green et al., 2008; Dupont-Nivet et al., 2010a; Najman et al., 2010; Wang et al., 2011].

[5] Regardless which of the proposed collision ages is preferred, the amount of shortening in Indian-affinity rocks in the Himalayan thrust belt (450-900 km [DeCelles et al., 2002; Long et al., 2011]) is much less than the amount of post-collisional plate convergence. Because of this reason, and because restorations of early Mesozoic Gondwana configurations suggest a size of Greater India smaller than $\sim 1000 \mathrm{~km}$ [Ali and Aitchison, 2005], most tectonic models of the India-Asia collision zone partition as much as two-thirds of India-Asia convergence into Asian lithosphere [e.g., Lee and Lawver, 1995; Tapponnier et al., 2001; Replumaz and Tapponnier, 2003; Royden et al., 2008]. However, geological records of the post-50 Ma shortening distributed within Tibet yield much smaller estimates of only $\sim 600 \mathrm{~km}$ [Dewey et al., 1988; Yin and Harrison, 2000; Johnson, 2002; Guillot et al., 2003]. Until recently, we have lacked structural studies from the remote interior regions of the Tibetan Plateau to accurately test these predictions. In the last decade, however, many new kinematic constraints from Tibet, the Tien Shan, the Pamir and Mongolia have been published. Here, we provide an updated restoration of shortening and extrusion in Asia for the Cenozoic. To test the various scenarios for intra-Asian deformation, we restore the deformation from Tajikistan to Vietnam and from Siberia to the Himalaya.

[6] Finally, we use the new reconstruction of intra-Asian shortening, which is independent from the age of collision, to evaluate the size of Greater India as a function of collision age. Our results show that even the youngest proposed collision age of $34 \mathrm{Ma}$ yields a significant mismatch between shortening recorded in Himalaya and contemporaneous Indian-plate subduction. We conclude with a dis- cussion of the implications of this mismatch for the composition of Greater Indian lithosphere.

\section{Approach}

[7] Classic plate reconstructions use rigid plates, and localize deformation at plate boundaries [Cox and Hart, 1986]. Alternatively, Tibetan lithosphere may be modeled as a thin-viscous sheet, in which lithosphere deforms homogeneously such that there are no horizontal strain gradients within a vertical column of lithosphere [England and Houseman, 1986; England and Molnar, 1997]. We use a combination of these approaches, subdividing the HimalayaTibetan orogen into rigid blocks, such as the Tarim basin, where no significant Cenozoic deformation is apparent, as well as deforming blocks, such as fold-thrust belts and extending basins. Because the latter typically exhibit deformation that is partitioned across many small-scale folds or faults, we chose to treat those areas as blocks that gradually deform between known boundaries, such as strike-slip faults or boundaries of extensional basins or fold-thrust belts.

[8] We use the freely available software package GPlates to make our reconstruction (http://www.gplates.org) [Boyden et al., 2010]. The rotation and shape files of our reconstruction are given in the auxiliary material. ${ }^{1}$ GPlates subdivides the surface into undeformable polygons (e.g., the Tarim basin, or the South China Block) and deformable topologies (e.g., the Tien Shan). For example, lines representing the boundaries of a deforming region move with respect to each other during the time span of deformation, changing the area in between according to geological constraints. GPlates interpolates plate or line motions with constant rates between known situations, leading to a continuously deforming plate reconstruction.

[9] The reconstruction presented here uses the India-Asia plate circuit of van Hinsbergen et al. [2011], which is based on the most recent plate kinematic constraints [e.g., Gaina et al., 2002; Merkouriev and DeMets, 2006; Cande et al., 2010]. We reconstruct Asian deformation with respect to stable Siberia. To allow comparison of our reconstructions to paleomagnetic data or mantle reference frames, Data Sets S1-S4 (rotation files) in the auxiliary material are available in a Siberia-fixed frame as shown in this paper, as well as in the paleomagnetic reference frame of Torsvik et al. [2008], the hybrid mantle reference frame of Torsvik et al. [2008] (which consists of the Indo-Atlantic hot spot frame of O'Neill et al. [2005] back to $100 \mathrm{Ma}$ and a true polar wandercorrected paleomagnetic reference frame of Steinberger and Torsvik [2008] before $100 \mathrm{Ma}$ ), and finally in the slabfitted mantle reference frame of van der Meer et al. [2010].

\section{Review}

[10] Reconstructions require a deformed pattern that is restored into an undeformed configuration. Here, crustal fragments, and their intervening sutures that built the Asian crust prior to the Cretaceous define this pattern. Available kinematic constraints from the India-Asia collision zone are summarized in Table 1 and Figures 2 and 3.

\footnotetext{
${ }^{1}$ Auxiliary material data sets are available at $\mathrm{ftp}: / / \mathrm{ftp}$. agu.org/apend/tc/ 2011tc002908. Other auxiliary material files are in the HTML.
} 
Table 1. Displacements Used in This Reconstruction ${ }^{\mathrm{a}}$

\begin{tabular}{|c|c|c|c|c|}
\hline Structure/Region & Sense & Amount & Age & Reference \\
\hline Lake Baykal & E-W extension & $7 \mathrm{~km}$ & $7-0 \mathrm{Ma}$ & San'kov et al. [2000] \\
\hline Mongolia ${ }^{\mathrm{b}}$ & $\mathrm{N}-\mathrm{S}$ shortening & $50 \mathrm{~km}$ & $23-0 \mathrm{Ma}$ & Cunningham [2005] \\
\hline Tien Shan ${ }^{\mathrm{b}}$ & $\mathrm{N}-\mathrm{S}$ shortening & $20-200 \mathrm{~km}$ & $23-0 \mathrm{Ma}$ & Avouac et al. [1993] and Yin et al. [1998] \\
\hline Chatkal range (north of Pamir) & $\mathrm{N}-\mathrm{S}$ shortening & $60 \mathrm{~km}$ & Cenozoic & Burtman et al. [1996] \\
\hline $\begin{array}{l}\text { Peter the First range } \\
\text { (north of Pamir) }\end{array}$ & $\mathrm{N}-\mathrm{S}$ shortening & $60 \mathrm{~km}$ & Cenozoic & Hamburger et al. [1992] \\
\hline Alai Valley (north of Pamir) & $\mathrm{N}-\mathrm{S}$ shortening & $20 \mathrm{~km}$ & $25-0 \mathrm{Ma}$ & Coutand et al. [2002] \\
\hline region north of Pamir & NE-SW shortening & $260 \mathrm{~km}$ & $23-0 \mathrm{Ma}$ & Bourgeois et al. [1997]; see text \\
\hline Tadjik Depression & NE-SW shortening & $150 \mathrm{~km}$ & $23-0 \mathrm{Ma}$ & Bourgeois et al. [1997] \\
\hline Tadjik Depression rotations & counterclockwise & $0-50^{\circ}$ & $23-0 \mathrm{Ma}$ & Thomas et al. [1994] \\
\hline Talas-Ferghana fault & rl strike-slip & $60 \mathrm{~km}$ & Cenozoic & Burtman et al. [1996] \\
\hline Altyn Tagh fault ${ }^{\mathrm{b}}$ & 11 strike-slip & $400 \mathrm{~km}$ & $30-0 \mathrm{Ma}$ & Cowgill et al. [2003] and Yue et al. [2004] \\
\hline Western Kunlun/Tianshuihai ${ }^{\mathrm{b}}$ & $\mathrm{N}-\mathrm{S}$ shortening & $140 \mathrm{~km}$ & $30-0 \mathrm{Ma}$ & Cowgill et al. [2003] \\
\hline Longmu-Goza fault & 11 strike-slip & $30 \mathrm{~km}$ & $10-0 \mathrm{Ma}$ & Raterman et al. [2007] \\
\hline Qilian Shan-Nan Shan-Qaidam $^{\mathrm{b}}$ & $\mathrm{N}-\mathrm{S}$ shortening & $140 \mathrm{~km}$ & $30-0 \mathrm{Ma}$ & see text \\
\hline Kongur Shan & E-W extension & $20 \mathrm{~km}$ & 9-0 Ma & Robinson et al. $[2004,2007]$ \\
\hline Karakoram fault, scenario $1^{\mathrm{c}}$ & rl strike-slip & $150 \mathrm{~km}$ & $13-0 \mathrm{Ma}$ & $\begin{array}{l}\text { Searle and Phillips [2007], Robinson [2009], } \\
\quad \text { and Bhutani et al. [2009] }\end{array}$ \\
\hline Karakoram fault, scenario 2 & rl strike-slip & $200-600 \mathrm{~km}$ & $25-0 \mathrm{Ma}$ & $\begin{array}{l}\text { Lacassin et al. [2004], Valli et al. [2007, 2008], } \\
\text { and Rolland et al. [2009]; Leloup et al. [2011] }\end{array}$ \\
\hline Gurla Mandhata core complex & E-W extension & $65 \mathrm{~km}$ & $10-0 \mathrm{Ma}$ & Murphy et al. [2000] \\
\hline Kashgar-Yecheng transfer system & rl strike-slip & $270 \mathrm{~km}$ & $30-0 \mathrm{Ma}$ & Cowgill $[2010]$ \\
\hline western Himalaya rotation & clockwise & $20^{\circ}$ & post-Eocene & $\begin{array}{l}\text { Klootwijk et al. }[1985,1986,1994] \text { and } \\
\text { Schill et al. }[2001]\end{array}$ \\
\hline Songpan Garzi belt ${ }^{\mathrm{b}}$ & N-S shortening & $200 \mathrm{~km}$ & $50-30 \mathrm{Ma}$ & Coward et al. [1988] and Spurlin et al. [2005] \\
\hline Qiangtang terrane & N-S shortening & $120 \mathrm{~km}$ & $50-20 \mathrm{Ma}$ & P. Kapp et al. $[2005]$ \\
\hline Qiangtang terrane & $\mathrm{N}-\mathrm{S}$ shortening & $400 \mathrm{~km}$ & $140-100 \mathrm{Ma}$ & P. Kapp et al. [2005; 2007a] and DeCelles et al. [2007] \\
\hline Lhasa terrane & $\mathrm{N}-\mathrm{S}$ shortening & $40 \mathrm{~km}$ & $50-20 \mathrm{Ma}$ & Kapp et al. $[2007 \mathrm{~b}]$ \\
\hline Lhasa terrane & $\mathrm{N}-\mathrm{S}$ shortening & $250 \mathrm{~km}$ & $100-50 \mathrm{Ma}$ & $\begin{array}{l}\text { Murphy et al. [1997], Leier et al. [2007], } \\
\text { and Volkmer et al. [2007] }\end{array}$ \\
\hline Lhasa terrane, rotation Linzizong & & $0^{\circ}$ & $50-0 \mathrm{Ma}$ & Dupont-Nivet et al. [2010a] \\
\hline Eastern Qiangtang rotation & clockwise & $50^{\circ}$ & Cenozoic & Otofuji et al. [1990] and Huang et al. [1992] \\
\hline Sichuan basin rotation & & $0^{\circ}$ & Cenozoic & Huang and Opdyke [1992] \\
\hline Gangdese thrust & $\mathrm{N}-\mathrm{S}$ shortening & $50 \mathrm{~km}$ & $30-24 \mathrm{Ma}$ & Yin et al. [1999a] and Murphy and Yin [2003] \\
\hline Great Counter thrust ${ }^{\mathrm{d}}$ & $\mathrm{N}-\mathrm{S}$ shortening & $16 \mathrm{~km}$ & $18-11 \mathrm{Ma}$ & Yin et al. [1999a] and Murphy et al. [2009] \\
\hline $\begin{array}{l}\text { Combined Gangdese and } \\
\text { Great Counter thrusts }\end{array}$ & $\mathrm{N}-\mathrm{S}$ shortening & $66 \mathrm{~km}$ & $30-11 \mathrm{Ma}$ & \\
\hline Kunlun fault & 11 strike-slip & $100 \mathrm{~km}$ & $10 \mathrm{Ma}$ & $\begin{array}{l}\text { Van der Woerd et al. [2000], Fu et al. [2005], } \\
\text { and Kirby et al. [2007] }\end{array}$ \\
\hline Longmenshan & E-W shortening & $25 \mathrm{~km}$ & $10 \mathrm{Ma}$ & Burchfiel et al. [2008] and Hubbard and Shaw [2009] \\
\hline Xianshuihe fault & 11 strike-slip & $70 \mathrm{~km}$ & $13 \mathrm{Ma}$ & $\begin{array}{l}\text { Allen et al. [1991], Roger et al. [1995], } \\
\quad \text { and Wang and Burchiel [2000] }\end{array}$ \\
\hline Nyaingtentanghla detachment & E-W extension & $25 \mathrm{~km}$ & $10 \mathrm{Ma}$ & Harrison et al. [1995] and J. L. D. Kapp et al. [2005] \\
\hline South China Block & E-ward motion & $80 \mathrm{~km}$ & $10 \mathrm{Ma}$ & Replumaz and Tapponnier [2003] \\
\hline E-W extension across Tibet ${ }^{b}$ & E-W extension & $100 \mathrm{~km}$ & $10 \mathrm{Ma}$ & He and Chery [2008] \\
\hline Red River Fault $\mathrm{b}^{\mathrm{b}}$ & rl strike-slip & $40 \mathrm{~km}$ & $8 \mathrm{Ma}$ & Replumaz et al. [2001] and Schoenbohm et al. [2006b] \\
\hline Red River Fault, scenario $1^{\mathrm{c}}$ & 11 strike-slip & $250 \mathrm{~km}$ & $30-20 \mathrm{Ma}$ & Searle [2006], Hall et al. [2008], and Fyhn et al. [2009] \\
\hline Red River Fault, scenario 2 & 11 strike-slip & $700 \mathrm{~km}$ & $30-15 \mathrm{Ma}$ & Tapponnier et al. [1986] and Leloup et al. [1995] \\
\hline Andaman Sea ${ }^{b}$ & $\mathrm{~N}-\mathrm{S}$ extension & $460 \mathrm{~km}$ & $11-0 \mathrm{Ma}$ & Curray et al. [1979, 1982] and Diament et al. [1992] \\
\hline Sagaing fault & rl strike-slip & $530 \mathrm{~km}$ & $11-0 \mathrm{Ma}$ & $\begin{array}{l}\text { Curray et al. }[1979,1982] \text { and } \\
\text { Khan and Chakraborty }[2005]\end{array}$ \\
\hline Shan Scarp & rl strike-slip & unknown & 40/30 Ma-11 Ma & $\begin{array}{l}\text { Bertrand et al. [2001], Bertrand and Rangin [2003], } \\
\text { and Searle et al. [2007] }\end{array}$ \\
\hline Mentawai and Sumatra fault & rl strike-slip & $70 \mathrm{~km}$ & ?Pliocene & Diament et al. [1992] and Schlüter et al. [2002] \\
\hline Sunda Strait & E-W extension & $70 \mathrm{~km}$ & $5-0 \mathrm{Ma}$ & Diament et al. [1992] and Schlüter et al. [2002] \\
\hline Rotation Indochina & clockwise & $10-20^{\circ}$ & Cenozoic & $\begin{array}{l}\text { Huang and Opdyke [1993], Charusiri et al. [2006], } \\
\text { and Aihara et al. [2007], Takemoto et al. [2009] }\end{array}$ \\
\hline Indo-Burman wedge & E-W shortening & $11 \mathrm{~km}$ & $2 \mathrm{Ma}$ & Maurin and Rangin [2009] \\
\hline Mae Ping fault & 11 strike-slip & $100-160 \mathrm{~km}$ & $40-23 \mathrm{Ma}$ & Tapponnier et al. [1986] and Fyhn et al. [2010a, 2010b] \\
\hline Three Pagodas-Tho Chu fault & 11 strike-slip & $100-160 \mathrm{~km}$ & $40-23 \mathrm{Ma}$ & Tapponnier et al. [1986] and Fyhn et al. [2010a] \\
\hline Three Pagodas-Tho Chu fault & rl strike-slip & minimal & $23-0 \mathrm{Ma}$ & Morley [2007] and Fyhn et al. [2010a, 2010b] \\
\hline
\end{tabular}

${ }^{\mathrm{a}}$ The scenario number refers to the location of this estimate, as indicated in Figure 3; rl (11) strike-slip, right- (left-) lateral strike-slip.

${ }^{\mathrm{b}} \mathrm{See}$ text for more details and references for this estimate.

${ }^{\mathrm{c}}$ Preferred scenario; see text for discussion.

${ }^{\mathrm{d}}$ A larger amount of shortening along the Great Counter thrust was used in our reconstruction to balance displacement along the Karakoram Fault; see text. 


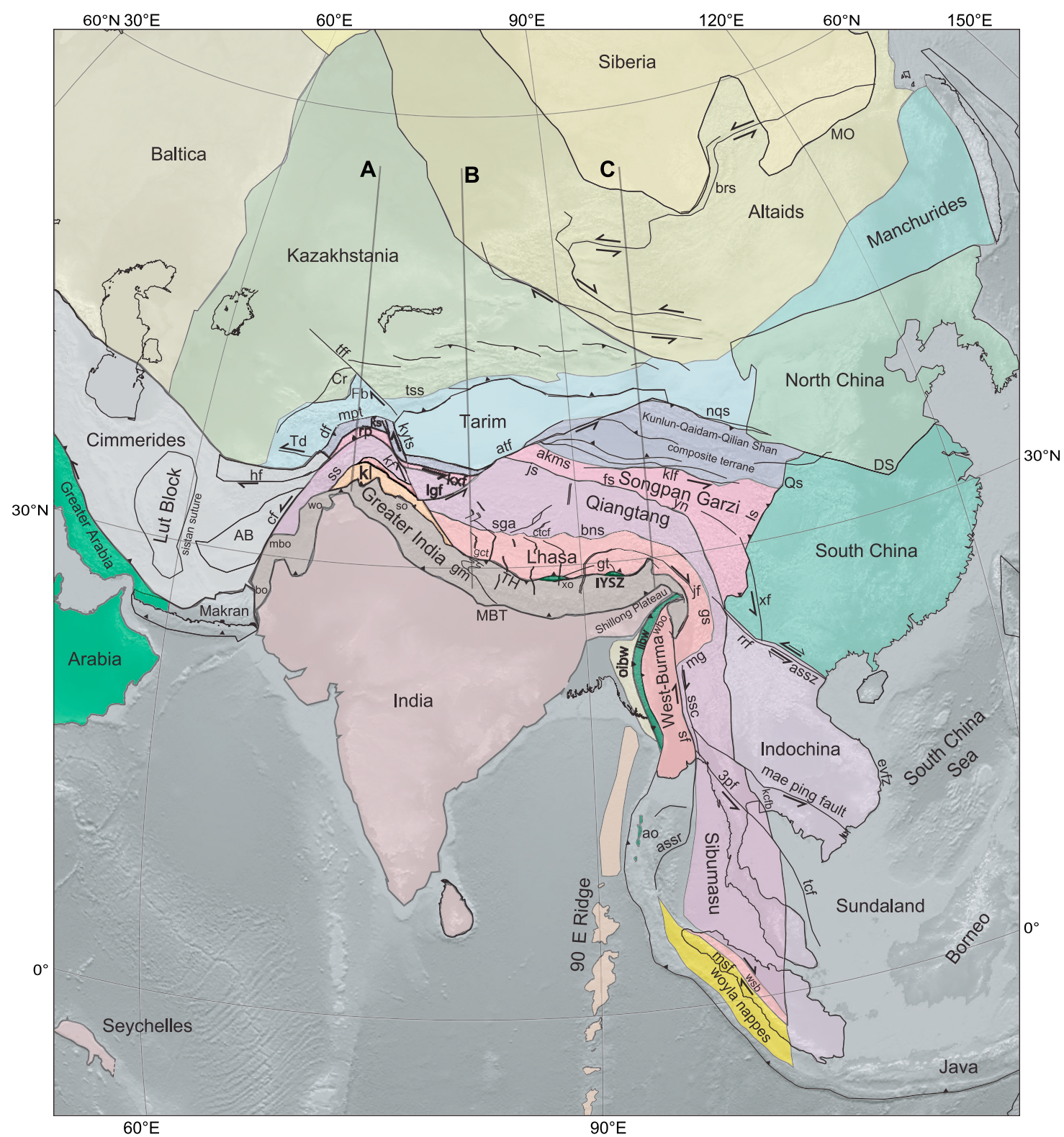

Figure 2. Simplified tectonic map of Asia, showing the main faults and boundaries of deforming regions discussed in this paper. Terranes and sutures of central and East Asia are modified after Yin and Harrison [2000], Cocks and Torsvik [2007], Pubellier [2008] and Torsvik and Cocks [2009] in a 3D Globe projection. Abbreviations are 3pf, Three Pagodas fault; AB, Afghan block; ao, Andaman ophiolite; akms, Ayimaqin-Kunlun-Mutztag suture; assr, Andaman Sea spreading ridge; assz, Ailao Shan shear zone; atf, Altyn Tagh fault; bns, Bangong-Nujiang suture; bo, Bela ophiolite; brs, Baykal rift system; cf, Chaman fault; Cr, Chatkal range; ctcf, Central Tibetan Conjugate fault system; df, Darvaz fault; DS, Dabie Shan; evfz, East Vietnam fault zone; Fb, Ferghana basin; gm, Gurla Mandhata metamorphic complex; fs, Fenguo Shan fold-and-thrust belt; gct, Great Counter Thrust; gs, Gaoligong shear zone; gt, Gangdese thrust; hf, Helmand fault; iibw, inner Indo-Burman wedge; IYSZ, Indus-Yarlung Suture Zone; jf, Jiali fault; js, Jinsha suture; kcfb, Khmer-Chanthaburi fault belt; kf, Karakoram fault; kl, Kohistan-Ladakh arc; klf, Kunlun fault; ks, Kongur Shan; kxf, Karakax fault; kyts, Kashgar-Yecheng transfer system; lgf, Longmu-Goza fault; 1s, Longmen Shan; mbo, Muslim Bagh ophiolite; nqs, North Qilian suture; MBT, Main Boundary Thrust; mg, Mogok metamorphic belt; MO, Mongol-Okhotsk suture; mpt, Main Pamir thrust; msf, Mentawai and Sumatra faults; oibw, outer Indo-Burmese wedge; Qs, Qinling Shan; rp, Rushan Pshart; rrf, Red River fault; sf, Sagaing fault; sga, Shiquanhe-Gaize-Amdo thrust system; so, Spontang ophiolite; ss, Shyok suture; ssc, Shan Scarp; tcf, Tho Chu fault; Td, Tadjik Depression; tff, Talas-Ferghana fault; TH, Tethyan Himalaya; tss, Tien Shan suture; wbo, west Burma ophiolite; wo, Waziristan ophiolite; wsb, West Sumatra block; xf, Xianshuihe fault; xo, Xigaze ophiolite; yn, Yushu-Nangqian fold-and-thrust belt. 


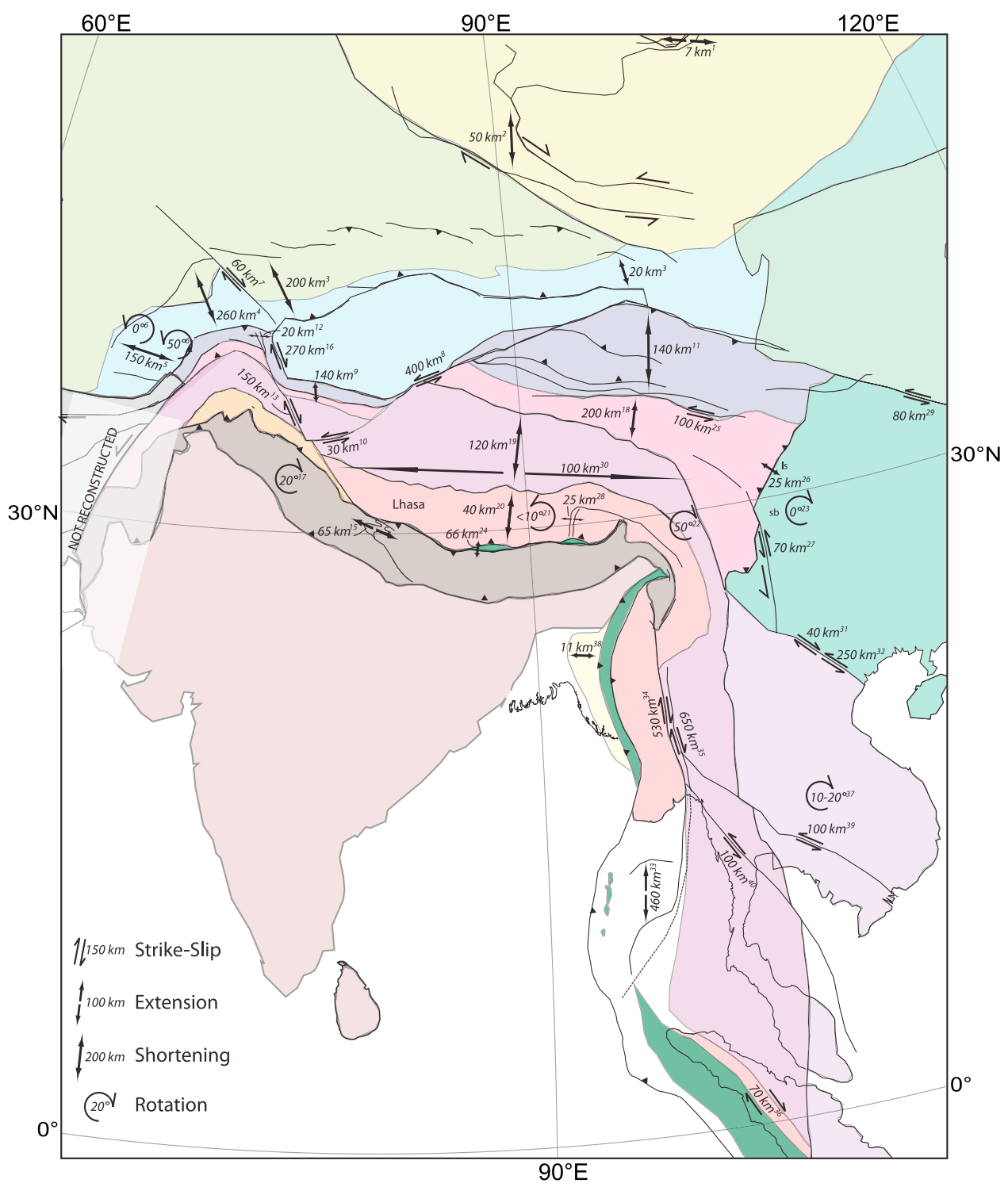

Figure 3. Summary of the kinematic constraints used as input in this reconstruction. Numbers in superscript refer to Table 1. See Figure 2 for explanation of basement blocks and structures.

\subsection{Continental Fragments of Asia}

[11] We study the region of Asia that underwent intense Cenozoic deformation. This area is surrounded by and (partly) includes the Kazakhstan block to the northwest, the Altaid collage and the Siberian craton to the north, the Manchuride collage and the North and South China blocks to the east, and cratonic India south of the Main Frontal Thrust to the south [Şengör et al., 1993; Sengör and Natal'in, 1996; Cocks and Torsvik, 2007; Pubellier, 2008; Torsvik and Cocks, 2009] (Figure 2).

[12] The youngest collisions in central and east Asia are the Triassic collision between the North and South China blocks, forming the Dabie Shan and the Qinling ranges [Zhao and Coe, 1987; Ratschbacher et al., 2003; Hacker et al., 2006], the late Triassic collisions between Sibumasu and Indochina, and Indochina and South China [Metcalfe, 1996; Zhou et al., 2008; Ferrari et al., 2008; Barber and Crow, 2009; Cai and Zhang, 2009; Roger et al., 2010] and the latest Jurassic closure of the Mongol-Okhotsk Ocean and collision of the Mongolian Altaids (also called Amuria) with Siberia [Enkin et al., 1992; Van der Voo et al., 1999b; Cogné et al., 2005; Metelkin et al., 2010]. Early Cretaceous $(\sim 125 \mathrm{Ma})$ paleomagnetic poles from Mongolia coincide with Eurasian reference poles [Hankard et al., 2007; van Hinsbergen et al., 2008]. These collision zones have been tectonically reactivated due to Cretaceous far-field tectonic stresses or internal body forces [Graham et al., 2001; Meng et al., 2003; Ratschbacher et al., 2003], but they can be considered as stable Eurasian continent, while major tectonic activity was dominated by collisions along the Eurasian margins. Below we review the crustal structure and available kinematic constraints for each area.

\subsection{Mongolia}

[13] Mongolia and southern Siberia contain strike-slip dominated regions including the Western Altai and the Gobi 
Altai, and the E-W extensional Lake Baykal basin, which can be viewed as an extensional step-over in a left-lateral strike-slip system (Figure 2). Total strike-slip displacements here are within tens of kilometers. The Lake Baykal rift system, which may have a pre-Cenozoic history unrelated to the India-Asia collision [Jolivet et al., 2009], accommodated $\sim 7 \mathrm{~km}$ of extension since 11-7 Ma [San'kov et al., 2000; ten Brink and Taylor, 2002]. The Western Altai accommodated $\sim 20-30 \mathrm{~km}$ of right lateral displacement since the Oligocene [Howard et al., 2003; Cunningham, 2005]. The Gobi Altai accommodated at least $15 \mathrm{~km}$ of sinistral strike-slip along the northern Bogd fault system since $5 \pm 3 \mathrm{Ma}$ [Vassallo et al., 2007; Cunningham, 2010]. Because many of the mountain ranges have not been studied in detail (W. D. Cunningham, personal communication, 2010), we assume a total intraMongolian shortening of $50 \mathrm{~km}$, twice as much as documented by Cunningham [2005], and assume a constant shortening rate since the onset of deformation around $23 \mathrm{Ma}$ [Howard et al., 2003]. Pre-Oligocene deformation of Mongolia and northwestern China dates back to the Mesozoic [Graham et al., 2001; Davis et al., 2002; Meng et al., 2003; Yuan et al., 2006; Darby and Ritts, 2007; Vassallo et al., 2007; Jolivet et al., 2007], and does not fall within the scope of our restoration.

\subsection{Tien Shan}

[14] The Tien Shan is developed on the upper Paleozoic to lower Mesozoic suture between the Tarim block and Kazakhstan [Allen et al., 1993; Şengör et al., 1993] (Figures 1 and 2). The Tarim basin has behaved as a stable sedimentary basin, with deformation localized along its margins [Graham et al., 1993; Yang and Liu, 2002]. The Tien Shan is bounded in the north and south by Neogene to Recent thrust faults [Avouac et al., 1993; Molnar, 1994; Yin et al., 1998; Burbank et al., 1999]. The range becomes narrower to the east, where it structurally connects to the Gobi Altai sinistral transpressional system [Cunningham et al., 1996] and accommodated $20-40 \mathrm{~km}$ of Cenozoic shortening [Yin et al., 1998]. Avouac et al. [1993] assumed that the Tien Shan is in isostatic equilibrium (but see Kosarev et al. [1993]) and estimated that Cenozoic N-S shortening increased from nearzero in the east to $\sim 200 \mathrm{~km}$ in the west. This lateral variation in shortening predicts a vertical axis rotation of the Tarim block with respect to Kazakhstan of $\sim 7^{\circ}$ around a pole at the eastern end of the Tien Shan [Avouac et al., 1993]. Lowtemperature thermochronology demonstrates a phase of rock uplift around 65-60 Ma in the Tien Shan [Jolivet et al., 2010]. This age predates most estimates for the India-Asia collision and kinematic data associated with this phase remain undocumented, so this deformation is not specifically included in our reconstruction. Sedimentological, stratigraphic and low-temperature thermochronological data indicate a significant increase of exhumation in the southern Tien Shan at 23 Ma [Hendrix et al., 1994; Yin et al., 1998; Yang and Liu, 2002; Sobel et al., 2006; Heermance et al., 2007; Jolivet et al., 2010]. Rock (and probably surface) uplift in the northern and eastern Tien Shan may have followed later, may have occurred in pulses, and the shortening rate may have increased through time [Bullen et al., 2003; Charreau et al., 2009; Sun and Zhang, 2009; Li et al., 2011]. Rock uplift and shortening rates are not necessarily proportionally linked, however, and no kinematic data are available to quantify shortening rate changes in the Tien Shan in the Miocene. For simplicity, we assume that shortening of the Tien Shan since 23 Ma has been continuous between the modern range-front thrusts.

[15] The gradual westward increase in Tien Shan elevation stops abruptly at the trans-crustal, dextral Talas-Ferghana strike-slip fault [Burtman, 1975; Trifonov et al., 1992; Burtman et al., 1996; Li and Chen, 2006; Korjenkov et al., 2010], which continues northward to faults that have not been active in the Cenozoic [Allen et al., 2001; Alexeiev et al., 2009]. The Talas-Ferghana fault has a post-late Cretaceous, dextral displacement of $60 \mathrm{~km}$ [Burtman et al., 1996]. West of the Talas-Ferghana fault, the Chatkal range in the north and the Alai range (or Southern Tien Shan) in the south are separated by the intervening Ferghana Basin, which is overthrusted by both ranges (Figure 1) [Cobbold et al., 1993; Burtman et al., 1996]. The Alai valley separates the Alai Range in the north from the Trans-Alai Range and the Main Pamir Thrust further to the south. The Main Pamir Thrust forms the boundary with the Pamir fold-and-thrust belt [Skobolev, 1977; Leith and Alvarez, 1985; Bourgeois et al., 1997; Burtman, 2000; Coutand et al., 2002] (Figures 1 and 2). Neogene thin-skinned folding and thrusting deformed sediments in the Tadjik Depression west of the Pamir salient (Figure 2). We adopted the map-view restoration of the Tadjik depression of Bourgeois et al. [1997] in our reconstruction. This restoration used structural geological data in combination with paleomagnetic constraints that demonstrate counterclockwise rotations that increase from $0^{\circ}$ in the western part of the Tadjik Depression to $\sim 50^{\circ}$ in the eastern part near the Darvaz fault at the boundary with the Pamir salient [Bazhenov et al., 1994; Thomas et al., 1994]. Bourgeois et al. [1997] showed that $150 \mathrm{~km}$ of WNW-ESE shortening in the Tadjik depression can be reconciled with the vertical axis rotation pattern assuming $240 \mathrm{~km}$ of NNW-ward indentation of the Pamir salient. Approximately $60 \mathrm{~km}$ of this shortening was accommodated in the Peter the First range (Figure 1), a south-verging fold-and-thrust belt to the northwest of the Pamir [Hamburger et al., 1992]. Thomas et al. [1993] used paleomagnetic results from Eocene to lower Miocene sediments to demonstrate a $20 \pm 11^{\circ}$ counterclockwise rotation of the Ferghana Basin, and inferred $110 \pm 60 \mathrm{~km}$ of shortening in the Chatkal range. Sediments in the Alai Valley have been shortened by $\sim 20 \mathrm{~km}$ in the Neogene [Coutand et al., 2002]. We assume that the remaining $50 \pm 60 \mathrm{~km}$ of shortening of the $240 \mathrm{~km}$ inferred by Bourgeois et al. [1997] is partitioned in the Alai Range.

\subsection{Tibet and the Pamir-Hindu Kush}

\subsubsection{Terranes and Subdivisions}

[16] Most intra-Asian Cenozoic deformation was accommodated south of the Tarim block in the Tibetan Plateau to the southeast, and the Pamir-Hindu Kush region to the west and southwest (Figure 1). The Tarim block is separated from the Tibetan Plateau by the sinistral Altyn Tagh strike-slip fault and the western Kunlun Shan fold-thrust belt [e.g., Molnar and Tapponnier, 1975] (Figure 2). The western Tarim basin is separated from terranes of the Pamir region by the Kashgar-Yecheng dextral strike-slip system [Cowgill, 2010]. The dextral Karakoram strike-slip fault separates Tibet and the Tarim basin in the east, from the Pamir-Hindu Kush region in the west [Molnar and Tapponnier, 1975]. 
[17] The Tibetan Plateau and Pamir-Hindu Kush regions exhibit a series of suture zones and intervening crustal fragments that collided in Paleozoic to Mesozoic time [SSengör, 1987; Dewey et al., 1988; Hsü et al., 1995; Yin and Harrison, 2000; Roger et al., 2010]. To the northeast of the Tibetan Plateau, the Qilian Shan-Nan Shan ranges, the Qaidam Basin and the eastern Kunlun Shan contain several Paleozoic sutures. We refer the reader to Gehrels et al. [2003] for details. Here, we only show the northernmost, North Qilian suture, and the southernmost, AyimaqinKunlun-Mutztagh suture [Yin and Harrison, 2000] and treat this region as a composite Kunlun-Qaidam-Qilian Shan terrane. The latter suture forms the northern boundary of the Songpan-Ganzi terrane (Figure 2)). The Songpan-Ganzi terrane is comprised largely of Triassic turbidites that were deposited in Paleo-Tethyan oceanic basins [Yin and Nie, 1993; Zhou and Graham, 1996; Roger et al., 2010], and is separated from the Qiangtang terrane by the upper Triassic-lower Jurassic Jinsha suture [Yin and Harrison, 2000; Pullen et al., 2008]. The Qiangtang terrane is juxtaposed with the Lhasa block to the south along the uppermost Jurassic-lower Cretaceous Bangong-Nujiang suture [Dewey et al., 1988; Yin and Harrison, 2000; J. L. D. Kapp et al., 2005; L.-L. Wang et al., 2008; Zhang, 2010]. The Eocene Indus-Yarlung suture zone (IYSZ) in the south separates the Lhasa terrane from the Himalaya.

[18] The Pamir-Hindu Kush region west of the Tibetan Plateau has been subdivided into continental fragments equivalent to the Tibetan terranes, in addition to the Kohistan intraoceanic-arc and Kohistan-Ladakh batholith [Schwab et al., 2004; Cowgill, 2010]. The Kohistan arc is bounded in the north by the $\sim 70$ Ma old Shyok suture [Burtman and Molnar, 1993; Searle et al., 1997; Schwab et al., 2004]. In our reconstruction, we follow Searle and Treloar [2010] and restore late Cretaceous ophiolite emplacement over Greater India (and Arabia [Gnos et al., 1997]), followed by collision of Greater India with the Kohistan arc in the Eocene.

[19] We do not reconstruct the western margin of the collision zone in Afghanistan and Pakistan because there is a general absence of kinematic data. We note, however, that there is evidence for Cenozoic extrusion of the Afghan Block westward along the conjugate Helmand and Chaman strike-slip faults [Tapponnier et al., 1981], and E-W closure of the Sistan ocean between the Afghan Block and the Lut Block in eastern Iran, which perhaps continued until Oligocene-Miocene times [Rezaei-Kahkhaei et al., 2010] (Figure 2). Given the kinematics of the known major faults and the $\mathrm{E}-\mathrm{W}$ compression in eastern Iran, restoring this region would probably indicate some westward lateral escape of the Afghan Block. The amount of westward motion, the timing, and the relationship between the Afghan Block and the blocks in Iran, however, remain subject for future work.

\subsubsection{The Altyn Tagh Fault and Its Terminations}

[20] The $1600 \mathrm{~km}$ long, lithosphere-scale [Wittlinger et al., 1998] sinistral Altyn Tagh fault (ATF) bounds the Tibetan Plateau in the north [Molnar and Tapponnier, 1975] (Figure 2). Displacement along the ATF is transferred into transpressional fold-and-thrust belts of the Western Kunlun Shan-Tianshuihe region in the west, and the Eastern Kunlun Shan-Qaidam-Qilian Shan-Nan Shan region in the east [Cowgill et al., 2003]. The central segment of the ATF is predominantly strike-slip [Cowgill et al., 2003; DupontNivet et al., 2004b]. Piercing point studies suggest displacements along the ATF ranging from 300 to $500 \mathrm{~km}$ [Ritts and Biffi, 2000; Cowgill et al., 2003; Gehrels et al., 2003; Yue et al., 2004, 2005; Ding et al., 2004].

[21] To the west, the ATF connects to the transpressional system of the western Kunlun Shan. The western Kunlun Shan overthrusts the Tarim basin to the north, is bounded in the west by the Kashgar-Yecheng transfer system, and is bounded in the south by the sinistral Karakax strike-slip fault. The Karakax fault coincides spatially with the Ayimaqin-Kunlun-Mutztagh suture [Matte et al., 1996; Mattern et al., 1996; Yang and Liu, 2002; Cowgill, 2010]. A balanced cross-section in the central-eastern part of the Western Kunlun Shan shows $\sim 100 \mathrm{~km}$ of Cenozoic upper crustal shortening [Cowgill, 2001], consistent with $>80 \mathrm{~km}$ of shortening estimated from isostatic equilibrium calculations [Lyon-Caen and Molnar, 1984]. South of the Karakax fault, the Tianshuihai range underwent post-late Cretaceous shortening along south-dipping thrusts [Yin and Harrison, 2000; Cowgill et al., 2003; Cao et al., 2009]. Cowgill et al. [2003] proposed that shortening in the Western Kunlun Shan decreases eastward, whereas in the Tianshuihai range, shortening increased eastward. Four hundred $\mathrm{km}$ of displacement along the $\mathrm{N} 70^{\circ} \mathrm{E}$ striking ATF corresponds to $\sim 150 \mathrm{~km}$ of $\mathrm{N}-\mathrm{S}$ shortening, and $\sim 350 \mathrm{~km}$ of eastward motion. The $\sim 150 \mathrm{~km}$ of N-S shortening may have been partitioned in the Western Kunlun Shan and Tianshuihai range, but it should be considered a maximum because it assumes rigid block translation of Tibet along the ATF. The amount of ATF displacement may increase eastward, accommodated by late Miocene and younger E-W extension and strike-slip faulting within Tibet (see section 4.3). The Karakax Fault does not crosscut and displace the Karakoram fault. Its displacement must hence be accommodated east of the Karakoram fault by E-W compression to its north, or E-W extension to its south, and its displacement after the initiation of the Karakoram fault was probably within tens of kilometers. Prior to Karakoram fault activity, the Karakax fault may have continued along the Ayimaqin-Kunlun-Mutztagh suture in the northern Pamir, although this remains untested by field studies. Splaying off of the southwestern termination of the ATF is the NE-SW striking Longmu-Goza sinistral strike-slip system south of the Tianshuihai range. Post-10 Ma displacement of 25-32 km along the LongmuGoza fault led to the formation of a restraining bend along the Karakoram Fault [Raterman et al., 2007].

[22] To the northeast, ATF displacement is accommodated in the Eastern Kunlun Shan-Qaidam-Qilian Shan-Nan Shan region. The Eastern Kunlun Shan transpressional system is separated from the Qilian Shan-Nan Shan foldand-thrust belt to the north by the Qaidam Basin (Figures 1 and 2). These thrust systems absorbed at least some of the motion along the ATF in the northeast. Shortening estimates in this region vary. Yin et al. [2008a] suggested that shortening along the northern margin of the Qaidam Basin varies along-strike between 20 and $60 \%$, and Yin et al. [2007] suggested that Cenozoic upper crustal shortening within the Qaidam basin decreases eastward from $>48 \%,(\sim 150 \mathrm{~km})$, to $<1 \%$. Zhou et al. [2006], on the other hand, suggested only $\sim 10 \%$ shortening for the Qaidam Basin. The Qilian Shan-Nan Shan belt is a thick-skinned fold-and-thrust belt 
with an estimated $150 \mathrm{~km}$ of NE-SW shortening since the Miocene [Tapponnier et al., 1990; Meyer et al., 1998]. The main trend of the fold-and-thrust belts in this region is $\sim \mathrm{N} 70^{\circ} \mathrm{W}$, along which a total of $\sim 260 \mathrm{~km}$ of shortening would accommodate all ATF displacement. Several authors have suggested that as much as $320 \mathrm{~km}$ of displacement of the ATF penetrated farther into the North China block prior to middle Miocene time [Yue and Liou, 1999; Yue et al., 2004; Darby et al., 2005]. Because the exact location and distribution of shortening in the eastern Kunlun-Qaidam-Qilian Shan-Nan Shan region remains enigmatic, we assume for simplicity that all motion along the ATF was accommodated south of the northern Qilian Shan front, and apply bulk shortening, evenly distributed over the area from the Eastern Kunlun Shan to the Qilian Shan.

[23] Yue et al. [2001, 2005] suggested that $360 \pm 40 \mathrm{~km}$ of ATF displacement occurred after 23 Ma. Cenozoic denudation of the Western [Sobel and Dumitru, 1997] and Eastern Kunlun Shan [Mock et al., 1999; Jolivet et al., 2001; Yin et al., 2008b; Clark et al., 2010] began since $30 \mathrm{Ma}$, coinciding with increased subsidence in the Tarim Basin [Graham et al., 1993; Yang and Liu, 2002] and the age of gouge developed along major thrusts within the range [Duvall et al., 2011]. Correlating uplift and erosion in NE Tibet to activity of the ATF, Jolivet et al. [2001] associated rock uplift and erosion in NE Tibet to slip along the ATF to argue ATF activity may have began as early as $40 \pm 10 \mathrm{Ma}$, and Yin et al. [2008b] argued that ATF-related deformation around the Qaidam basin may even have started $65 \mathrm{Ma}$ ago. However, early Cenozoic deformation in the eastern part of NE Tibet was associated with clockwise rotations and Dupont-Nivet et al. [2002] argued that Eocene vertical axis rotations in this region were caused by right-lateral transpression between Qaidam and the South China block. We assume that $400 \mathrm{~km}$ of displacement along the ATF, and the accommodating transpression in the northeastern and southwestern terminations, occurred at a constant rate since $30 \mathrm{Ma}$.

\subsubsection{Karakoram Fault and Kashgar-Yecheng} Transfer System

[24] The Karakoram fault and the Kashgar-Yecheng transfer system (KYTS) to the west of the Tarim basin are separated by the Kunlun terrane, which there trends NNWSSE in the eastern Pamir [Cowgill, 2010]. The Karakoram fault and KYTS form a transform system that accommodates northwestward motion of the Pamir-Hindu Kush region with respect to both Tibet and the Tarim basin. The KYTS transferred convergence along the North Pamir Thrust to shortening in the Western Kunlun Shan [Cowgill, 2010]. The Karakoram fault has transferred shortening in the RushanPshart fold-and-thrust belt to shortening in the Himalaya and along the IYSZ [e.g., Strecker et al., 1995; Murphy et al., 2000; Robinson, 2009]. Between the Rushan-Pshart foldand-thrust belt and the Main Pamir Thrust the N-S trending Kongur Shan extensional detachment system has accommodated up to $34 \mathrm{~km}$ of E-W extension since $\sim 7-8 \mathrm{Ma}$, and the Karakoram Fault does not connect with the Main Pamir Thrust [Robinson et al., 2004, 2007].

[25] The KYTS was noted by Burtman and Molnar [1993] and Sobel and Dumitru [1997] and described in detail by Cowgill [2010] as a $\sim 50 \mathrm{~km}$ wide transpressional zone of anastomosing strike-slip faults with a total dextral displacement of $\sim 270-280 \mathrm{~km}$. Age constraints for the onset of activity of the Kashgar-Yecheng system are inferred to coincide with the 37-23 Ma onset of shortening in the Western Kunlun Shan [Sobel and Dumitru, 1997; Cowgill et al., 2003]. We assume a $30 \mathrm{Ma}$ onset age for the KYTS. Assuming a 37 or $23 \mathrm{Ma}$ onset of deformation would decrease or increase the rate of shortening in the northern Pamir by $1-2 \mathrm{~cm} / \mathrm{yr}$, respectively.

[26] The age of, and displacement along the Karakoram Fault are strongly debated. One school of thought argues for a maximum displacement of the fault of $150 \mathrm{~km}$ [Searle, 1996; Phillips et al., 2004; Schwab et al., 2004; Searle and Phillips, 2007; Robinson, 2009], with slip initiating as recently as 14-12 Ma [Bhutani et al., 2009; Streule et al., 2009; Wang et al., 2009]. Murphy et al. [2000] concluded that the Karakoram Fault propagated southward around $10 \mathrm{Ma}$, crosscutting the IYSZ and linking with the GurlaMandhata metamorphic complex (Figure 2). About $65 \mathrm{~km}$ of displacement accumulated after this linkage. In this scenario, the Karakoram fault has transferred shortening in the Rushan-Pshart to the Main Boundary Thrust of the southern Himalaya since the late Miocene [Murphy and Copeland, 2005].

[27] A second school of thought argues that slip on the Karakorum Fault initiated at or before $25 \mathrm{Ma}$, with much higher total displacements, mainly based on alternative correlations of terranes and sutures from Tibet to the PamirHindu Kush (see overview by Cowgill [2010]). Slip estimates provided by this school have systematically decreased from initially as high as $1000 \mathrm{~km}$ [Peltzer and Tapponnier, 1988], to $600 \mathrm{~km}$ [Lacassin et al., 2004], >280 to $400 \mathrm{~km}$ [Valli et al., 2007, 2008], $300 \mathrm{~km}$ [Rolland et al., 2009], and most recently to $200 \mathrm{~km}$ [Leloup et al., 2011]. Besides the timing of fault initiation, another difference is the interpretation that the Karakoram fault does not link with the Gurla-Mandhata core complex [Lacassin et al., 2004]. Instead, it was suggested to transfer slip to dextral strike-slip faults along the Bangong-Nujiang suture zone (i.e., KarakorumJiali fault zone [Armijo et al., 1989]) and IYSZ [e.g., Replumaz and Tapponnier, 2003]. We discuss the geometric and kinematic consequences of both views later.

\subsubsection{Pamir-Hindu Kush}

[28] The Pamir-Hindu Kush region, from the Pakistan Himalaya in the south to the Main Pamir Thrust in the north, is a northward convex orogenic belt. A Benioff zone is imaged beneath the Main Pamir Thrust to $250 \mathrm{~km}$ depth [Hamburger et al., 1992; Burtman and Molnar, 1993; Pavlis and Das, 2000], consistent with seismic tomographic images showing $>300 \mathrm{~km}$ of nearly vertical subducted lithosphere [Nikolaev et al., 1985; Van der Voo et al., 1999a; Negredo et al., 2007; Zhao et al., 2010]. Cowgill [2010] interpreted the northern part of the Pamir salient as a half-orocline, with only the western part of the region having undergone counterclockwise vertical-axis rotations and thrusting [Thomas et al., 1994]; the eastern part was bounded by the KYTS.

[29] Paleomagnetic data from the western Himalayas and the Hindu Kush support northward convex oroclinal bending, with locally varying counterclockwise rotations of up to $100^{\circ}$ in the western limb, and up to $20^{\circ}$ clockwise rotation in the eastern limb since the Eocene [Klootwijk et al., 1985, 1986, 1994; Zaman and Torii, 1999; Schill et al., 2001]. We reconstruct a northward decrease of clockwise rotation of 
the eastern limb of the Pamir-Hindu Kush orocline, with full accommodation by rotation in the south, and full accommodation by strike-slip motion in the north.

[30] Shortening estimates in the Pamir-Hindu Kush region between the Main Pamir Thrust and the IYSZ are scarce. Burtman and Molnar [1993] provided a crude estimate of $300 \mathrm{~km}$ of Cenozoic shortening. Contractional deformation, metamorphism, and magmatism started in the Central and Southern Pamir zones in late Cretaceous-Paleocene time [Searle et al., 2010]. We reconstruct the Pamir-Hindu Kush based on kinematic constraints from the bounding faults, the Tadjik Depression, paleomagnetic constraints, and the notion that the total amount of Cenozoic shortening in the Pamir must exceed the shortening in Tibet to form the northward convex orocline.

\subsubsection{N-S Shortening in Tibet}

[31] The Lhasa, Qiangtang and Songpan-Ganzi terranes of the Tibetan Plateau were significantly shortened through folding and thrusting during the Cretaceous and Paleogene. The bulk of shortening of the Qiangtang and Lhasa terranes predates $\sim 50 \mathrm{Ma}$ : the Qiangtang terrane underwent $\sim 50 \%$ shortening $(\sim 300 \mathrm{~km})$ between 140 and $100 \mathrm{Ma}$ during the Lhasa-Qiangtang collision [P. Kapp et al., 2005, 2007a; DeCelles et al., 2007]. Subsequently, the Lhasa terrane underwent $\sim 50 \%(\sim 250 \mathrm{~km})$ shortening between 100 and $50 \mathrm{Ma}$ [Murphy et al., 1997; Ding and Lai, 2003; Kapp et al., 2003, 2007a, 2007b; Guynn et al., 2006; Volkmer et al., 2007]. These largely Cretaceous thrust systems straddle the Bangong-Nujiang suture, and have not been displaced more than $\sim 15 \mathrm{~km}$ by younger strike-slip faults along the Central Tibet Conjugate Fault Zone (CTCFZ, Figure 2) [Taylor et al., 2003; P. Kapp et al., 2005; Ratschbacher et al., 2011]. The Bangong-Nujiang suture plays a fundamental role in the model of major extrusion of Indochina away from central Tibet [Replumaz and Tapponnier, 2003; Royden et al., 2008]. The extrusion model follows the suggestion of, e.g., Armijo et al. [1989] that $>700 \mathrm{~km}$ of sinistral displacement accumulated between the Qiangtang and Lhasa terranes during the Oligocene and early Miocene. Field evidence from the Bangong-Nujiang suture in western and central Tibet, however, shows a laterally continuous E-W belt of Cretaceous thrust faults and associated basins that underwent only minimal reactivation by thrusting at 30-20 Ma [P. Kapp et al., 2003, 2005]. Thus, field observations from the plateau interior preclude the major strike-slip faulting that is postulated in the extrusion scenario.

[32] Percentages of Paleogene shortening in Tibet decrease from north to south, and we subdivide the Tibetan Plateau into three belts accordingly. The northern belt includes the Paleogene Fenghuo Shan-Nanqian fold-thrust belt, which is bounded in the north by the Anyimaquen-Kunlun suture and includes the Jinsha suture zone [Coward et al., 1988]. The Fenghuo Shan fold-and-thrust belt underwent at least $80 \mathrm{~km}$ of Paleogene shortening (43\%) [Coward et al., 1988; Zhang and Zheng, 1994] and is unconformably overlain by only gently folded Miocene sediments [Leeder et al., 1988; Smith and Xu, 1988; Liu et al., 2001; C. Wang et al., 2008; Wu et al., 2008]. Apatite fission track analyses show rapid 30-22 Ma cooling in the Fenghuo Shan [C. Wang et al., 2008] and the Fenghuo Shan is intruded by $31 \pm 1 \mathrm{Ma}$ undeformed syenite [Harris et al., 1988]. Spurlin et al. [2005] documented $>110 \mathrm{~km}(>43 \%)$ of shortening in the Yushu-Nangqian region along strike to the east of the Fenghuo Shan, mainly between $\sim 50 \mathrm{Ma}$ and $37 \mathrm{Ma}$ [Horton et al., 2002]. The Tanggula Shan underwent major N-S shortening recorded by folded lower Paleogene sediments that are unconformably overlain by only weakly deformed Oligocene sediments and lavas [Wang et al., 2002; C. Wang et al., 2008; Lippert et al., 2011]. We assume that the consistent intense Paleogene shortening documented from the Yushu-Nangqian and Fenguo Shan regions is representative for the entire Songpan-Ganzi belt, and apply $\sim 50 \%$, or $\sim 200 \mathrm{~km} \mathrm{N-S}$ shortening between 50 and $30 \mathrm{Ma}$.

[33] Estimates of Cenozoic shortening by thrusting in the southern Qiangtang terrane (between 50 and $30 \mathrm{Ma}$ ) and along the Bangong-Nujiang suture zone (between 30 and $20 \mathrm{Ma})$ are $\sim 25 \%(\sim 120 \mathrm{~km})$ in total [P. Kapp et al., 2003, 2005, 2007a; Lippert et al., 2011]. Shortening of the Lhasa terrane after deposition of the widespread 69-47 Ma Linzizong volcanics [He et al., 2007; Lee et al., 2009] was minimal, was localized along relatively small thrusts and did not exceed $\sim 15 \%(\sim 40 \mathrm{~km})$ between $50 \mathrm{Ma}$ and $20 \mathrm{Ma}$ [He et al., 2007; Kapp et al., 2007b].

[34] Contractional deformation shortened the Indus-Yarlung suture zone in Cenozoic time. The top-to-the-south Gangdese thrust [Harrison et al., 1992; Yin et al., 1994, 1999a] placed Gangdese arc and forearc rocks over suturezone and Tethyan Himalayan rocks to the south between 30 and $24 \mathrm{Ma}$ and accommodated a minimum of $\sim 40-50 \mathrm{~km}$ shortening [Yin et al., 1994, 1999a; Murphy and Yin, 2003]. In middle Miocene time, the IYSZ was further shortened along the top-to-the-north Great Counter thrust system, backthrusting suture zone and Tethyan Himalayan rocks over the Gangdese arc and forearc by at least $16 \mathrm{~km}$ [Yin et al., 1999a; Murphy et al., 2009].

[35] Some paleomagnetic data from the Lhasa and Qiangtang terrane are available [Chen et al., 1993; Cogné et al., 1999; Liu et al., 2003; Dupont-Nivet et al., 2010a Liebke et al., 2010; Lippert, 2010; Lippert et al., 2011]. Given the spatial resolution of the currently available data, and the variable clockwise and counterclockwise rotations reported, the most conservative interpretation is that rotations are controlled by local structures, without a wholesale rotation of the Tibetan Plateau [Lippert, 2010]. Consistently clockwise rotations were reported from the Qiangtang terrane in eastern Tibet [Dupont-Nivet et al., 2002, 2004a]. The magnitudes of post-Cretaceous clockwise rotation increase eastward to $\sim 50^{\circ}$ in eastern Tibet [Otofuji et al., 1990; Huang et al., 1992; Huang and Opdyke, 1993; Sato et al., 1999; Yoshioka et al., 2003], and 90 clockwise in the Three Rivers region [Sato et al., 2001] (Figure 1). The Sichuan basin underwent no rotation [Huang and Opdyke, 1992]. The amount of rotation in eastern Tibet is roughly proportional to a change in the trend of the Qiangtang terrane from E-W to NNW-SSE. This has been interpreted as a result of Cretaceous to Cenozoic dextral shearing of the Qiangtang terrane along the western boundary of the South China Block as a result of shortening of the Tibetan Plateau [England and Molnar, 1990; Dupont-Nivet et al., 2002, 2004a].

\subsubsection{E-W Extension in Tibet and E-W Shortening in the Longmen Shan}

[36] The central and southern Tibetan Plateau, and in places the Himalaya, began extending E-W via the forma- 
tion of N-S trending (half-)grabens in the middle to late Miocene [Armijo et al., 1986; Burchfiel et al., 1991; Coleman and Hodges, 1995; Yin et al., 1999b; Murphy et al., 2002; Garzione et al., 2003; Taylor et al., 2003; Jessup and Cottle, 2010; Leloup et al., 2010; Saylor et al., 2010]. Estimates for the onset of E-W extension, based on stratigraphic analyses of associated basins and low-temperature thermochronology of uplifted footwall rocks, cluster around 14-8 Ma [Burchfiel et al., 1991; Coleman and Hodges, 1995; Harrison et al., 1995; Blisniuk et al., 2001; Garzione et al., 2003; J. L. D. Kapp et al., 2005]. The distributed nature of the N-S trending grabens leads to an eastward increasing rate of eastward motion of the Tibetan Plateau with respect to the Tarim block. This eastward increase is clearly observed in GPS measurements [Shen et al., 2001; He and Chery, 2008]. Much of the cumulative slip is accommodated in the north along the sinistral Kunlun fault, with a displacement of $100 \pm 20 \mathrm{~km}$ in its central segment since $10 \pm 2 \mathrm{Ma}$ [Van der Woerd et al., 2000, 2002; Fu et al., 2005; Fu and Awata, 2007; Kirby et al., 2007]. Toward the east, slip along the Kunlun fault gradually decreases with sinistral slip probably being transferred northward into the eastern Kunlun Shan [Kirby et al., 2007; Duvall and Clark, 2010].

[37] The east directed Longmen Shan thrust system bounding the western margin of the Sichuan basin in eastern Tibet was predominantly active during the Mesozoic [Wang et al., 1989; Mattauer, 1992; Chen and Wilson, 1996; Li et al., 2003; Wilson et al., 2006; Zheng et al., 2006; Roger et al., 2008, 2010; Robert et al., 2010]. It was reactivated during the late Miocene (11-8 Ma) recorded by ${ }^{40} \mathrm{Ar} /{ }^{39} \mathrm{Ar}$ and $(\mathrm{U}-\mathrm{Th}) / \mathrm{He}$ cooling ages in its hanging wall [Kirby et al., 2002; Godard et al., 2009], and renewed subsidence in the Sichuan Basin [Wang et al., 1989; Zheng et al., 2006]. The fault system remains active today [Burchfiel et al., 2008]. Approximately $20-25 \mathrm{~km}$ of E-W Neogene shortening has been documented in the Longmen Shan thrust system [Wallis et al., 2003; Burchfiel et al., 2008; Hubbard and Shaw, 2009]. The South China block moved $\sim 80 \mathrm{~km} \mathrm{SE}$-ward with respect to Siberia [Replumaz and Tapponnier, 2003]. E-W compression in the Longmen Shan demonstrates that eastern Tibetan crust moved eastward at a higher rate than South China. The Sichuan basin behaved as a rigid indenter in late Neogene time [Clark and Royden, 2000], with Tibetan crust moving around the northern edge of the Sichuan Basin along dextral strike-slip faults in the Qinling Shan since 9-4 Ma [Enkelmann et al., 2006]. SE-directed motion of fragments of Tibet and the South China Block occurred between the sinistral Xianshuihe fault, and the dextral Jiali fault southwest of the Sichuan basin (Figure 2). 60-80 km of post-8-10 Ma displacement has been documented for the Xianshuihe fault [Allen et al., 1991; Wang and Burchfiel, 2000], and some additional displacement between 13 and 10 Ma may have occurred [Roger et al., 1995]. The Xianshuihe fault terminates in the south against the Red River Fault [Schoenbohm et al., 2006b]. The amount of displacement along the Jiali fault is unknown.

[38] We estimate $\sim 100 \mathrm{~km}$ of post 14-12 Ma extension from Tibet. This value is determined from the $\sim 20 \mathrm{~km} \mathrm{E-W}$ shortening in the Longmen Shan combined with the $\sim 80 \mathrm{~km}$ SE ward motion of the south China block with respect to North China (Table 1, Figure 3).

\subsection{Mainland SE Asia}

\subsubsection{SE Asian Terranes and Their Connection to Tibet}

[39] The Qiangtang and Lhasa terranes correlate with preCenozoic continental terranes in SE Asia (i.e., 'Sundaland') through the narrow region between the Eastern Himalayan syntaxis and South China-known as the Three Rivers region (Figures 1 and 2). The simplest and most common subdivision of Sundaland distinguishes among the Indochina, Sibumasu and West Burma/west Sumatra blocks, and the Andaman forearc and Burmese ophiolites (Figure 2).

[40] Given the apparent structural continuity of the Qiangtang and Sibumasu blocks [Pubellier, 2008] and the similar ages of the Jinsha and Sibumasu-Indochina sutures, it seems likely that Sibumasu and Qiangtang are part of the same microcontinent, that collided with Indochina/South China and the Songpan-Ganzi terrane, respectively, in the late Triassic [Mattauer, 1992; Kapp et al., 2000; Ferrari et al., 2008; Cai and Zhang, 2009].

[41] Sibumasu is presently bounded in the west by the West Burma Block, along the Miocene, dextral Sagaing fault [Curray et al., 1979] (Figure 2). In Myanmar, the western margin of the Sibumasu terrane was intruded by a Jurassic to lower Cretaceous arc ( 170-120 Ma) [Barley et al., 2003; Searle et al., 2007], with younger (120-50 Ma) granitoids found to the west of the Sagaing Fault [Barley et al., 2003]. To the northwest of the Sagaing fault, serpentinite exposures contain zircon populations in jadeite that span an age range of 165-120 Ma [Shi et al., 2009]. These rocks are interpreted to have formed in an oceanic subduction channel that extended beneath the Jurassic-early Cretaceous arc in Sibumasu. The age range of this subduction-collision history is time-equivalent to that of the Bangong-Nujiang suture and therefore the West Burma Block may be correlative with the Lhasa block [Searle et al., 2007; Zhou et al., 2008].

\subsubsection{Mainland Sundaland and the Red River, Three Pagodas and Mae Ping Faults}

[42] Sundaland is bounded in the north by the $>1000 \mathrm{~km}$ long Red River Fault (RRF) [e.g., Peltzer and Tapponnier, 1988]. In the last $\sim 8 \mathrm{Myr}$, the RRF accumulated $40 \mathrm{~km}$ of dextral displacement [Replumaz et al., 2001; Schoenbohm et al., 2006a]. Earlier in the Cenozoic motion along the RRF was sinistral. This sinistral motion forms the basis for models of major SE-ward extrusion of Sundaland from between the Himalayas and the Qiangtang block [Peltzer and Tapponnier, 1988; Armijo et al., 1989; Leloup et al., 1995, 2001; Replumaz and Tapponnier, 2003; Royden et al., 2008]. Major controversy exists regarding the amount of sinistral displacement along the RRF. An initial estimate of $330 \pm$ $60 \mathrm{~km}$ [Lacassin et al., 1993] was revised to $700 \pm 200 \mathrm{~km}$ by the same group [Leloup et al., 1995]. Chung et al. [1997] proposed $600 \mathrm{~km}$ of displacement. Searle [2006], however, argued that the basins, sutures and volcanic belts used as piercing points cannot be demonstrated to be lateral equivalents and that the amount of displacement remains elusive. Fyhn et al. [2009] analyzed the offshore eastern continuation of the RRF in the East Vietnam fault zone (Figure 2); they concluded that sinistral displacement of the RRF is only $\sim 250 \mathrm{~km}$. Hall et al. [2008] made a detailed plate restoration of SE Asia and concluded a similarly modest amount of 
displacement along the RRF. In the discussion section we address the implications of both estimates ( 250 versus $750 \mathrm{~km}$ or more).

[43] The age of slip along the RRF is also controversial. Its displacement was originally suggested to be kinematically linked to the opening of the South China Sea between 32 and $16 \mathrm{Ma}$ [Briais et al., 1993], corresponding to 30 and $17 \mathrm{Ma}$ using the timescale of Cande and Kent [1995]. Recently, Searle [2010] suggested a maximum age range of 32-22 Ma, based on deformed and crosscutting granites in the Red River shear zone. Wang et al. [2000] presented cooling ages from rocks in the Ailao Shan to suggest a shorter, 27-22 Ma slip history. Fyhn et al. [2009] challenged the connection of the RRF to the South China Sea spreading center based on analyses of seismic lines offshore western Vietnam. They concluded that the RRF is directly connected to the East Vietnam Fault Zone, and that the bulk of the displacement predated the middle Oligocene, with perhaps several tens of kilometers after that. In the reconstruction by Hall et al. [2008], a large part of the South China Sea opened in response to southward subduction of a proto-South China Sea. This interpretation is based on a clear record of subduction from Borneo until the early Miocene. For a detailed reconstruction of southern Sundaland, we refer to Hall [2002] and Hall et al. [2008]: We assume that all sinistral displacement along the RRF occurred between 30 and 20 Ma.

[44] Southern mainland Sundaland is crosscut by the Mae Ping fault (a.k.a. the Wang Chao fault) and the Three Pagodas fault. The latter may be kinematically linked with the Tho Chu fault zone in the Bay of Thailand [Fyhn et al., 2010a]. Tapponnier et al. [1986] estimated $160 \mathrm{~km}$ of displacement for both the Three Pagodas and Mae Ping faults, of which Smith et al. [2007] suggested 10-30 km occurred in the Oligocene, and the rest in the Eocene. Lacassin et al. [1993] suggested that Mae Ping displacement was at least $35-45 \mathrm{~km}$. The analyses of Fyhn et al. [2010a, 2010b] of the basins offshore southern Thailand and Vietnam support sinistral shear, and suggest a displacement of $\sim 50-100 \mathrm{~km}$ for the Mae Ping fault and up to $100 \mathrm{~km}$ of displacement along the Three Pagodas. Tjia and Liew [1996] suggested a $70 \mathrm{~km}$ dextral inversion of the Three Pagodas fault, but Fyhn et al. [2010a] concluded that this phase was of minor importance. Offshore stratigraphic and seismic data restrict sinistral motion along the Three Pagodas and Mae Ping fault zones to the late Eocene and Oligocene [Morley, 2007; Fyhn et al., 2010a, 2010b]. We reconstruct $100 \mathrm{~km}$ of displacement along the Mae Ping and Three Pagodas faults between 40 and $23 \mathrm{Ma}$ (Table 1 and Figure 3).

\subsubsection{West Burma Block, Sagaing Fault and Shan Scarp}

[45] To the west, Sundaland is separated from the West Burma Block by a dextral strike-slip zone, which includes the Oligocene to early Miocene Shan Scarp shear zone and the late Miocene to Recent Sagaing Fault. The Sagaing Fault connects to the north with the Main Boundary Thrust of the Himalaya [G. Wang et al., 2008; Maurin and Rangin, 2009; Yin et al., 2010]. To the south, it connects with the $\sim \mathrm{N}-\mathrm{S}$ extensional spreading center of the Andaman Sea, which accommodated separation of the West Burma Block from the West Sumatra Block [Curray et al., 1979, 1982;
Jarrard, 1986; McCaffrey, 1992] (Figure 2). Extension in the Andaman Sea began around $11 \mathrm{Ma}$, and led to seafloor spreading since 4-5 Ma [Kamesh Raju et al., 2004; Khan and Chakraborty, 2005; Chakraborty and Khan, 2009]. The total Miocene displacement of the Sagaing Fault was estimated at $\sim 460 \mathrm{~km}$ based on a restoration of the Andaman Sea [Curray et al., 1979, 1982; Mitchell, 1981]. Bertrand and Rangin [2003] concluded that a total displacement since $4 \mathrm{Ma}$ is $100-150 \mathrm{~km}$. This latter estimate assumes no extension in the Andaman Sea prior to seafloor spreading. Approximately $450 \mathrm{~km}$ of displacement is consistent with the amount of India-Asia convergence since $\sim 10 \mathrm{Ma}$ and supports the interpretation that the West Burma Block has moved with India since this time. Spreading in the Andaman Sea transfers slip along the Sagaing Fault to the slower slipping dextral Mentawai and Sumatra faults that partition the strike-slip component of oblique subduction below Sumatra. Displacement along these faults is determined by $50-70 \mathrm{~km}$ of Pliocene extension in the Sunda Strait [Diament et al., 1992; Malod et al., 1995; Malod and Kemal, 1996; Schlüter et al., 2002]. This $50-70 \mathrm{~km}$ should be added to the $450 \mathrm{~km}$ of Andaman Sea extension to arrive at a displacement of the Sagaing fault of $510-530 \mathrm{~km}$ since $\sim 11 \mathrm{Ma}$.

[46] To the east of the Sagaing fault, a N-S trending, highgrade metamorphic belt of several tens of kilometers wide is exposed in the Shan Scarp [Socquet and Pubellier, 2005]. The Shan Scarp is a steeply dipping, NNW striking dextral strike-slip shear zone [Bertrand and Rangin, 2003]. To the north, it branches into the E-W trending Mogok belt, which exposes $\mathrm{N}$ and $\mathrm{S}$-dipping foliations with $\mathrm{NNW}$ trending lineations and bivergent shear-sense indicators [Bertrand and Rangin, 2003; Searle et al., 2007]. Cooling ages of metamorphic rocks range from $\sim 30 \mathrm{Ma}$ in the south to $\sim 18 \mathrm{Ma}$ in the north of the Shan Scarp, and $15 \mathrm{Ma}$ in the Mogok belt [Bertrand et al., 2001]. The Mogok belt continues northward to the Gaoligong shear-zone along the Bangong-Nujiang suture, southeast of the Himalayan syntaxis [G. Wang et al., 2008]. Similar to the Shan Scarp, the Gaoligong is a dextral strike-slip shear zone that yielded cooling ages of $\sim 28 \mathrm{Ma}$ [Wang et al., 2006]. It experienced a younger, late Miocene to Recent brittle transtensional episode [G. Wang et al., 2008]. There is no estimate for the total amount of dextral strike-slip accommodated along the Shan Scarp, but the metamorphic record is interpreted to reflect significant dextral motion between the West Burma Block and Sibumasu since the late Eocene or early Oligocene. This is consistent with the presence of late Eocene to Miocene transtensional basins in central Myanmar, located between the Sagaing fault in the east and the Indo-Burma wedge to the west. These basins have been inverted by dextral transpression since $\sim 10$ Ma [Maurin and Rangin, 2009].

[47] The Indo-Burman wedge is a $1200 \mathrm{~km}$ long, westverging fold-and-thrust belt [Brunnschweiler, 1966; Gansser, 1980; Johnson and Alam, 1991]. It consists of Cretaceous to Oligocene turbidite sequences in the inner wedge that underlie ophiolites, and Paleozoic and older metasediments [Acharya and Mitra, 1986], and Miocene to Quaternary sediments of the Bengal fan in the outer wedge [Maurin and Rangin, 2009] (Figures 1 and 2). At least $11 \mathrm{~km}$ of shortening have accumulated in the outer wedge since $2 \mathrm{Ma}$ [Maurin and 
Rangin, 2009]. The inner wedge, which is bounded by $\sim \mathrm{N}-\mathrm{S}$ trending dextral strike-slip faults and thrusts, is intensely deformed due to E-W shortening. The total amount of E-W shortening in the inner wedge is unknown, however, in part because it includes a strong dextral transpressional component [Maurin and Rangin, 2009]. At present, 30\% of the dextral shear between India and Sundaland is partitioned along the strike-slip zones in the inner Indo-Burma wedge [Vigny et al., 2003; Maurin and Rangin, 2009].

\subsubsection{Three Rivers Region and Gaoligong Fault}

[48] Late Miocene and younger deformation northwest of Sundaland accommodated the southward transfer of material from the Tibetan Plateau through the Three Rivers region between the eastern Himalayan syntaxis and the South China Block. GPS measurements [Allmendinger et al., 2007; Sol et al., 2007] show that along the eastern margin of the Tibetan Plateau, SSE-directed motion is partitioned into N-S sinistral strike-slip along the Xianshuihe Fault and a minor component of E-W shortening. To the south, GPS velocity vectors curve around the eastern Himalayan syntaxis and become W-directed with respect to Eurasia. These velocities follow the main structural trend, e.g., along the Gaoligong fault which curves from N-S in the north to E-W into the Mogok belt to the south [G. Wang et al., 2008]. The region of westward-directed GPS velocity vectors south of the Himalayan syntaxis is characterized by $\mathrm{N}-\mathrm{S}$ trending active normal faults that originated in the late Miocene $(\sim 8.5 \mathrm{Ma})$, and were especially active in the Pliocene [G. Wang et al., 2008]. These GPS velocity patterns suggest that most southward east Tibetan motion today, and probably at least since at the Pliocene, is transferred to the Indo-Burma wedge.

\subsubsection{Paleomagnetism of Sundaland}

[49] Many paleomagnetic studies have been conducted in Sundaland to constrain vertical axis rotations and paleolatitudinal changes associated with the motion along the RRF. These studies, all based on Mesozoic to Eocene red beds from Thailand, Vietnam, the Three Rivers region in southern China, and Myanmar, generally conclude that mainland Sundaland had a significant southward motion component with respect to South China, with attendant Cenozoic clockwise rotation. The amount of clockwise rotation varies strongly from $0^{\circ}$ in southern Vietnam [Chi and Dorobek, 2004] to $70^{\circ}$, or even larger rotations in the Shan Thai deformed belt south of the RRF [Yang et al., 1995; Aihara et al., 2007; Sato et al., 2007; Tanaka et al., 2008]. Most authors argue for $\sim 10-20^{\circ}$ regional clockwise rotation of mainland Sundaland and strong rotations associated with distributed, dextral strike-slip deformation in the Shan Thai region close to the RRF [Huang and Opdyke, 1993; Charusiri et al., 2006; Aihara et al., 2007; Takemoto et al., 2009]. Southern Sundaland, on the other hand, is characterized by counterclockwise rotations of $\sim 20-40^{\circ}$ (Thai-Malai peninsula and Borneo) since late Cretaceous time [Richter et al., 1999; Yamashita et al., 2011], and $50^{\circ}$ on Borneo in the Neogene [Fuller et al., 1999]. It remains uncertain whether these data indicate regional block rotations or local deformation associated with sinistral strike-slip tectonism [e.g., Hall et al., 2008; Fyhn et al., 2010a].

[50] Many paleomagnetic studies have argued for major Cenozoic southeastward displacement of Sundaland along the RRF. This conclusion is based on the findings of steeper inclinations in rocks from mainland Sundaland than predicted by the Eurasian APWP. Estimates typically have errors of 5-10 ${ }^{\circ}$ and report southward latitudinal displacements of $7-$ 14 ${ }^{\circ}$ [Yang and Besse, 1993; Yang et al., 1995, 2001; Sato et al., 1999, 2001, 2007; Chi and Dorobek, 2004; Takemoto et al., 2005]. We discuss the tectonic implications of these reports in section 4 .

\section{Interpretation: Retrodeforming Intra-Asian Shortening and Extrusion}

\subsection{Reconstruction of Greater Asia}

[51] Reconciling the kinematic constraints of intra-Asian deformation (Table 1 and Figure 3 ) leads to the evolution of Greater Asian deformation as shown in Figures $4 \mathrm{a}-4 \mathrm{f}$. Figure 5 illustrates the amount of intra-Asian shortening and Sundaland extrusion since $50 \mathrm{Ma}$. Figure 6 illustrates the portion of India-Asia convergence that is accommodated in the overriding plate (i.e., Greater Asia) for three modern longitudes corresponding to the western, central and eastern regions of the collision zone. In this section, we summarize the main findings of this reconstruction. In following sections, we discuss subregions in more detail. Our intra-Asian shortening reconstruction uses the low end-member estimates for displacements of the Karakoram fault and RRF, rather than larger estimates that would lead to $700 \mathrm{~km}$ or more of SE-ward extrusion of Sundaland [Lee and Lawver, 1995; Replumaz and Tapponnier, 2003; Royden et al., 2008] (Figure 7). We discuss the differences between our reconstruction and models that predict major extrusion in section 4.6.

[52] We estimate a total of $\sim 600 \mathrm{~km}$ of post-50 Ma shortening at the longitude of eastern Tibet $\left(\sim 95.5^{\circ} \mathrm{E}\right)$ (Figure 6). This deformation is partitioned between $\sim 450 \mathrm{~km}$ of N-S Paleogene shortening in the Tibetan Plateau, and up to $\sim 150 \mathrm{~km}$ of $\mathrm{N}-\mathrm{S}$ shortening associated with slip along the ATF, which is accommodated in NE Tibet. At the longitude of central Tibet $\left(\sim 82^{\circ} \mathrm{E}\right), \sim 450 \mathrm{~km}$ of Tibetan shortening, a $\sim 150 \mathrm{~km} \mathrm{~N}-\mathrm{S}$ shortening component associated with the ATF, and $\sim 150 \mathrm{~km}$ of shortening in the Tien Shan and Mongolia result in $\sim 750 \mathrm{~km}$ of shortening since $50 \mathrm{Ma}$. In the western segment $\left(\sim 72^{\circ} \mathrm{E}\right)$, south of the Pamir Hindu-Kush region, the total amount of intraAsian shortening is $\sim 1050 \mathrm{~km}$ since $50 \mathrm{Ma}$. This estimate is based on $\sim 350 \mathrm{~km} \mathrm{~N}-\mathrm{S}$ shortening associated with $\sim 400 \mathrm{~km}$ of cumulative right-lateral displacement along the $\mathrm{N} 30^{\circ} \mathrm{W}$ trending Karakoram fault and KYTS relative to Tibet (which underwent $\sim 450 \mathrm{~km}$ of shortening since $50 \mathrm{Ma}$ ), and $250 \mathrm{~km}$ of shortening north of the Main Pamir Thrust.

[53] Additional post-collisional N-S shortening in southern Tibet can be inferred from the observation that Cretaceous to Eocene Gangdese arc-related granites are exposed immediately north of the IYSZ [e.g., Chiu et al., 2009]. The Xigaze forearc that must have developed above the Neotethyan subduction zone and south of the magmatic arc has thus been entirely consumed by shortening (e.g., underthrusting or subduction erosion). Our restoration of the Gangdese and Great Counter thrusts assumes a pre-Oligocene size of the Xigaze forearc of $\sim 100 \mathrm{~km}$. Forearc basins are typically $166 \pm 60 \mathrm{~km}$ wide [Gill, 1981]; shallow dipping slabs may increase this width to $>400 \mathrm{~km}$ [Gutscher et al., 
2000]. We emphasize that our restored forearc width is an underestimate and more shortening probably accumulated directly after collision with the Tethyan Himalaya around $50 \mathrm{Ma}$. Because the India-Asia convergence rate around $50 \mathrm{Ma}$ was more than $150 \mathrm{~km} / \mathrm{Myr}$ [van Hinsbergen et al., 2011], and the uncertainty in collision age is on the order of several million years, we consider the forearc to disappear upon collision and do not specifically include it in our total shortening budget.

[54] Finally, we note that the total amount of shortening in the eastern segment is subject to the largest uncertainty. The $600 \mathrm{~km}$ estimated assumes that shortening measured in central Tibet is also valid in the east, where no estimates are available. This may be incorrect, however, no detailed field observations are available to support or refute this assumption. Indeed, the total amount of India-Asia con-
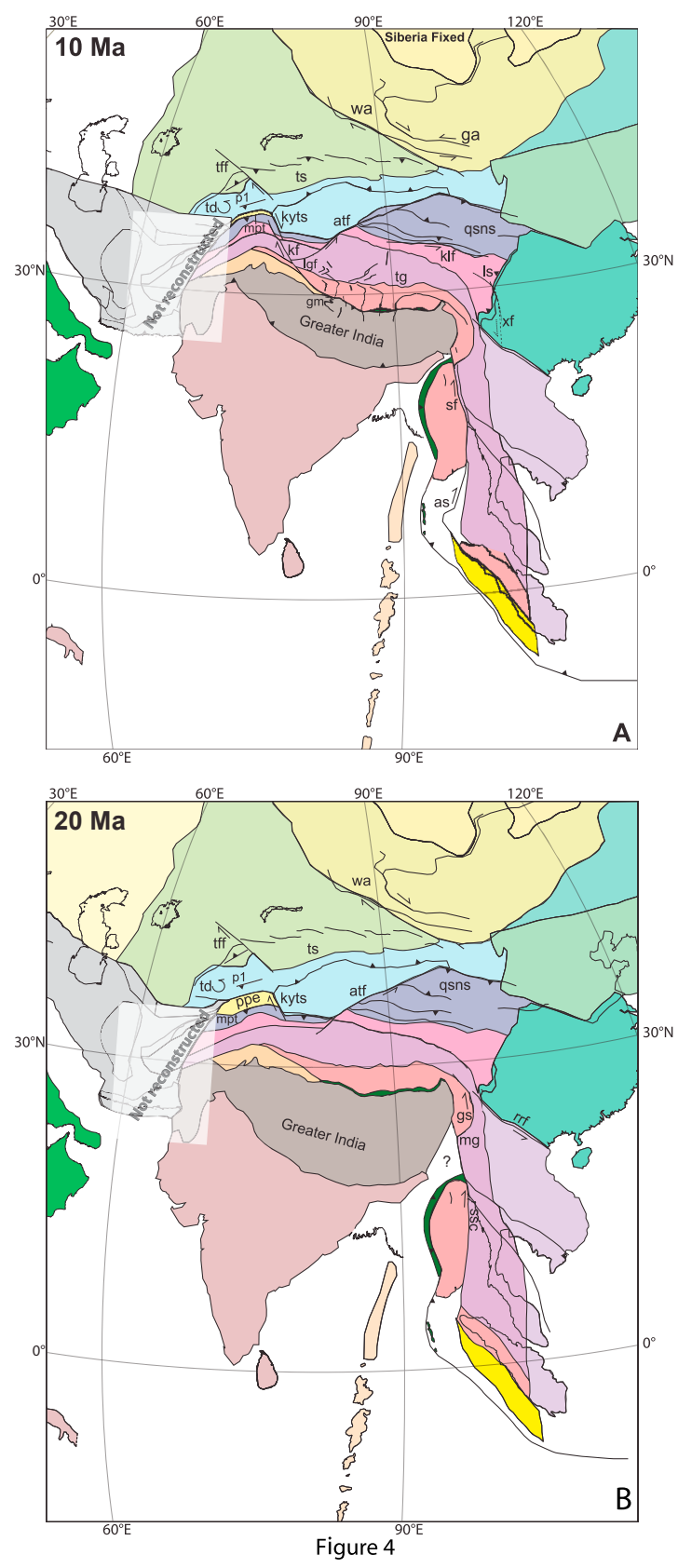

vergence since $\sim 50 \mathrm{Ma}$ is largest in the east $(\sim 3200 \mathrm{~km}$ [van Hinsbergen et al., 2011]) whereas the total amount of intraAsian shortening is lowest; this appears counterintuitive. In addition, seismic tomographic images suggest that the main Tethyan subduction zone curves southward more gradually in eastern Tibet than shown in our reconstruction [Van der Voo et al., 1999a, Hafkenscheid et al., 2006; Replumaz et al., 2010]. The reentrant east of the collision zone prior to $50 \mathrm{Ma}$ (Figure 4) may therefore be incorrect, and the amount of shortening in eastern Tibet may be underestimated in our reconstruction. Future structural geological work in this region, as well as vertical axis rotation analysis of the Lhasa terrane, is required to improve the reconstruction in this area.

[55] Our estimates for intra-Asian shortening are somewhat larger than previous estimates of $\sim 600 \mathrm{~km}$ [Dewey et al., 1988; Yin and Harrison, 2000; Johnson, 2002; Guillot et al., 2003]. The main difference arises from the inclusion of the Tien Shan in our reconstruction. Direct comparison of paleomagnetic data from southern Tibet with those from Mongolia and Siberia indicate $1100 \pm 500 \mathrm{~km}$ of Cenozoic intra-Asian convergence [Dupont-Nivet et al., 2010a, 2010b; Lippert et al., 2011], which is consistent with our reconstruction.

\subsection{Deformation North of Tibet and the Pamir}

[56] The amount of shortening of the Tien Shan directly east of the Talas-Ferghana fault is estimated at $200 \mathrm{~km}$ [Avouac and Tapponnier, 1993; Yin et al., 1998]. Assuming that the $60 \mathrm{~km}$ of dextral displacement along the TalasFerghana fault is constant along the fault [Burtman et al., 1996], this requires $260 \mathrm{~km}$ of total shortening in Eurasian lithosphere to the west of the Talas-Ferghana fault. This is similar to the estimate of $240 \mathrm{~km}$ of Bourgeois et al. [1997], which is based on the rotation and shortening patterns in the Tadjik Depression. Assuming $110 \mathrm{~km}$ of shortening in the Chatkal range [Thomas et al., 1993], a $60 \mathrm{~km}$ offset along the Talas-Ferghana fault allows $50 \mathrm{~km}$ of shortening to the north of the offset marker of Burtman et al. [1996] in the

Figure 4. Reconstruction of configurations of pre-Cenozoic terranes in Asia in a 3D Globe projection and a Siberia-fixed reference frame at (a) 10, (b) 20, (c) 30, (d) 40, (e) 50, and (f) $60 \mathrm{Ma}$. Structures that are active at the restored time slice are indicated. Abbreviations are 3pf, Three Pagodas fault; as, Andaman Sea; atf, Altyn Tagh fault; evfz, East Vietnam fault zone; ga, Gobi Altai; gm, Gurla Mandhata metamorphic complex; gs, Gaoligong shear zone; kf, Karakoram fault; kl, Kohistan-Ladakh intraoceanic arc; klf, Kunlun fault; Longmu-Goza fault; kyts, KashgarYesheng transfer system; Lh, Lhasa shortening; ls, Longmen Shan; mbt, Main Boundary Thrust; mg, Mogok metamorphic belt; mpf, Mae Ping fault; mpt, Main Pamir Thrust; p1, Peter the First range; ppe, Proto-Pamir embayment; qsns, Qilian Shan-Nan Shan; Qt, Qiangtang shortening; rrf, Red River fault; sf, Sagaing fault; Sg, Songpan-Ganzi shortening; ssc, Shan Scarp; td, Tadjik Depression; tff, Talas-Ferghana fault; tg, Tibetan grabens; ts, Tien Shan; wa, Western Altai; xf, Xianshuihe fault; xfa, Xigaze forearc. 

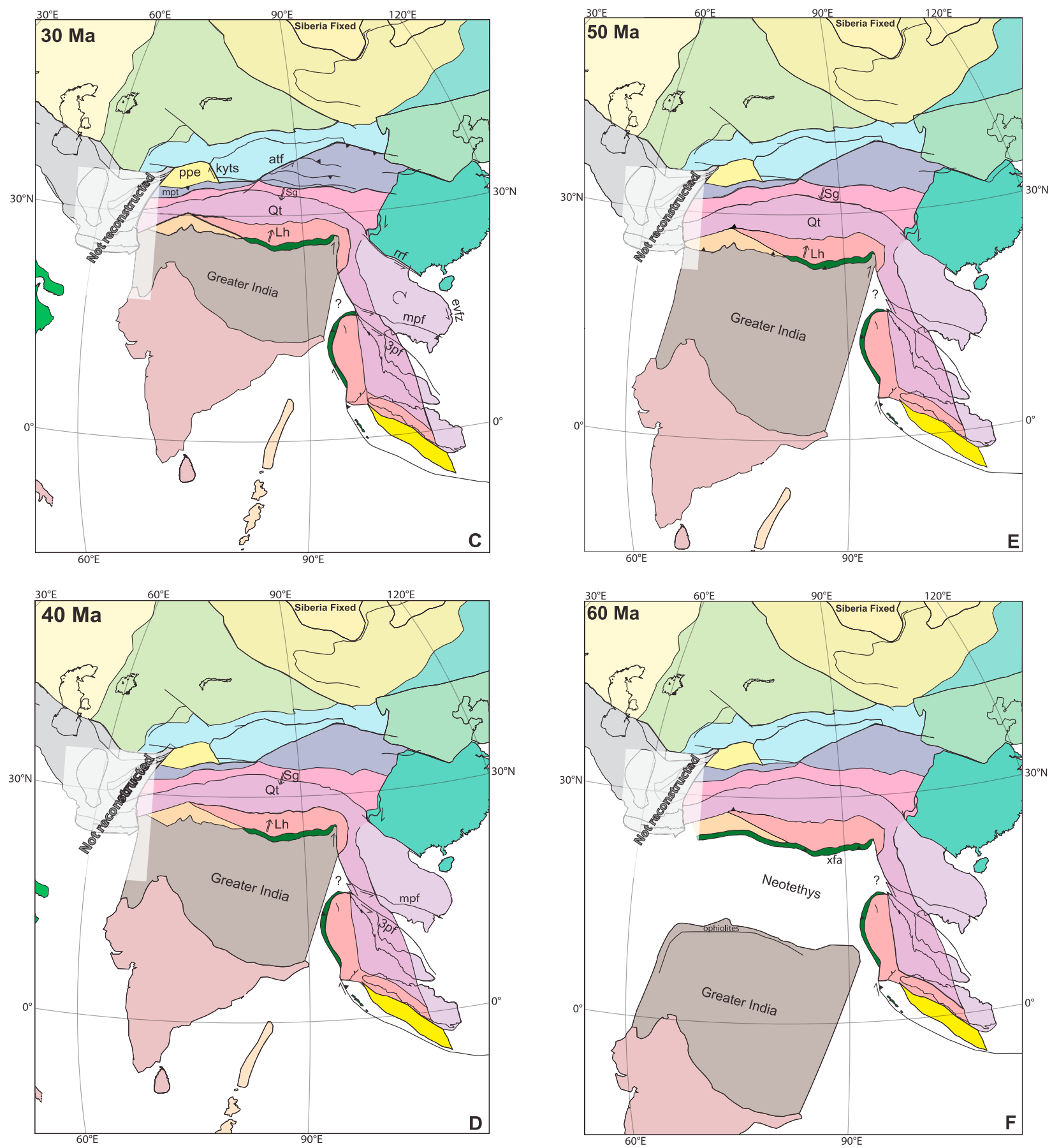

Figure 4. (continued)

central Tien Shan. This implies that the remaining $150 \mathrm{~km}$ of shortening in the eastern Tien Shan accumulated in the southern half of the belt. This prediction is consistent with the interpretation that deformation began earlier in the south than in the north [Hendrix et al., 1994; Yin et al., 1998; Yang and Liu, 2002; Bullen et al., 2003; Sobel et al., 2006; Heermance et al., 2007; Charreau et al., 2009; Sun and Zhang, 2009; Li et al., 2011]. Moreover, shortening to the south of the Chatkal range should have been $150 \mathrm{~km}$ as well, in order to maintain the dextral offset along the Talas-Ferghana fault.

\subsection{Miocene E-W Extension in Tibet and Activity of the Karakoram and Altyn Tagh Faults}

[57] GPS measurements and active seismicity demonstrate that the sinistral ATF and the dextral Karakoram 


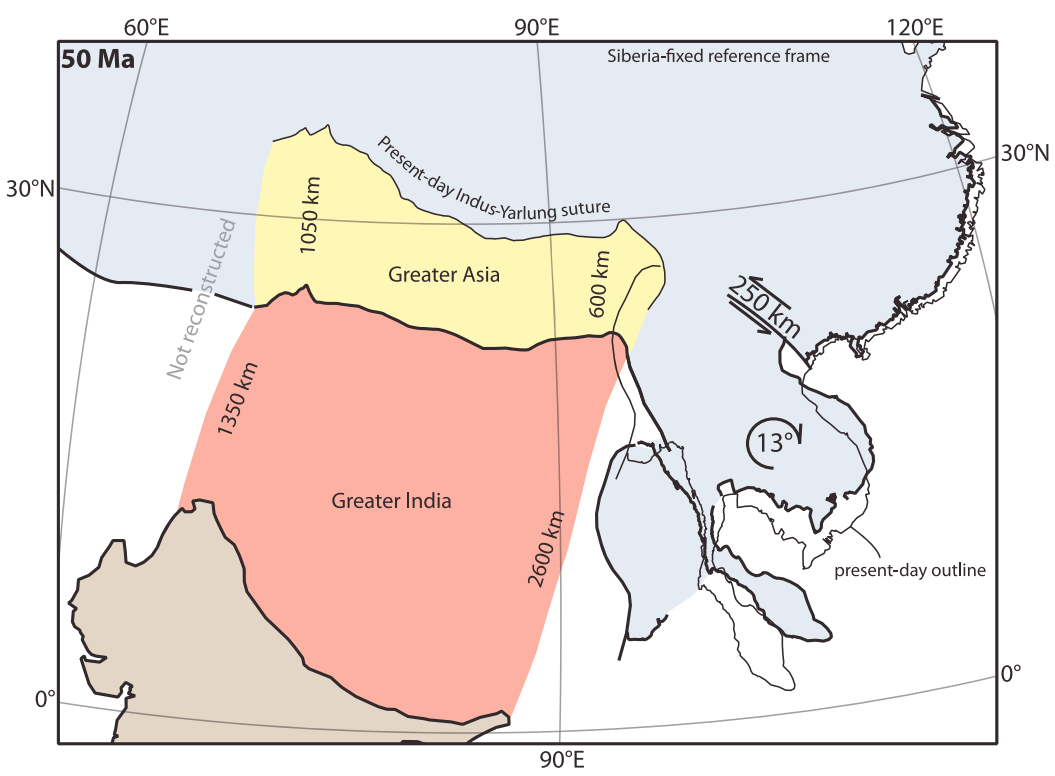

Figure 5. Cartoon illustrating the reconstructed size of Greater Asia, i.e., the total amount of intra-Asian shortening north of India, defined by the position of the IYSZ today and the reconstructed position $50 \mathrm{Ma}$ ago. In this paper we assume that the Tethyan Himalaya collided with Asia at $50 \mathrm{Ma}$. This collision age has no bearing on the amount of intra-Asian shortening. Map is in a Siberia-stable reference frame in a 3D Globe projection; the position of India with respect to stable Asia is based on the plate circuit of van Hinsbergen et al. [2011].

fault are active today, and geological studies suggest that they have been simultaneously active since at least the late Miocene [e.g., Zhang et al., 2004; He and Chery, 2008]. Approximately $100 \mathrm{~km}$ of distributed E-W extension has accumulated in the Tibetan Plateau since $\sim 13 \mathrm{Ma}$ (Table 1 and Figure 3). This extension is kinematically compatible with eastward increasing sinistral motion along of the ATF after $13 \mathrm{Ma}$. East of the central segment of the ATF, however, E-W extension in Tibet appears to be entirely accommodated by slip along the left-lateral Kunlun Fault [e.g., Van der Woerd et al., 2000; Jolivet et al., 2001]. He and Chery [2008] showed that across central Tibet $\left(84-95^{\circ} \mathrm{E}\right)$, from the ATF to the Himalayan arc, E-W extension rates are $8-10 \mathrm{~mm} / \mathrm{yr}$. At these rates, it would take $10-12.5 \mathrm{Ma}$ to accumulate the $\sim 100 \mathrm{~km}$ of total $\mathrm{E}-\mathrm{W}$ extension estimated in Tibet. This is consistent with the initiation age of $\mathrm{N}$-trending grabens in Tibet.

[58] The region north of the Kunlun fault, however, has undergone, and is still characterized by sinistral transpression. It is not possible to kinematically link this transpression directly to E-W extension in Tibet. Rather, the N-S shortening component south of the ATF appears to increase eastward since the late Miocene. Therefore, we restore a minor $\left(\sim 3^{\circ}\right)$ counterclockwise rotation of Tibet relative to Tarim around a pole located at the Karakoram fault-Karakax junction. This rotation produces E-W extension in central Tibet, and dextral transpression in NE Tibet.

[59] In this scenario, the Tibetan Plateau is a crustal block that has rotated counterclockwise with respect to Tarim around a pole of rotation near the western Kunlun ShanKarakoram junction and has deformed internally. This kinematic pattern has characterized deformation in Tibet since the late Miocene. Over the same time interval, the Tarim basin has rotated by similar magnitude but in an opposite direction with respect to Siberia. Thus, the net rotation of Tibet with respect to Siberia is negligible. A counterclockwise rotation of Tibet with respect to Tarim would produce transpression along the ATF, but transpressional deformation along its central segment is minor. Eastwest extension to the south of the central ATF segment transfers this transpressional component eastward into NE Tibet, whereas the E-W component of motion south of NE Tibet is absorbed by the Kunlun Fault (Figure 8). In our reconstruction, the left-lateral motion of the ATF and the observation that western Tibet is not significantly displaced with respect to Tarim is a direct consequence of the opposing rotations of Tarim and Tibet, with respect to Siberia.

[60] The ATF has been continuously active since at least the latest Oligocene [Yue et al., 2001, 2004; Yang and Liu, 2002; Zhuang et al., 2011]. The ATF can only be active simultaneously with the Karakoram fault if Tibet is E-W extending or otherwise, it should crosscut and offset the Karakoram fault. The onset of E-W extension in Tibet at 14-12 Ma [Burchfiel et al., 1991; Coleman and Hodges, 1995; Harrison et al., 1995; Blisniuk et al., 2001; Garzione et al., 2003] is contemporaneous with the onset of slip along the Karakoram fault of 14-12 Ma suggested by [Bhutani et al., 2009; Streule et al., 2009; Wang et al., 2009; Searle et al., 2010]. The much older ages of $25 \mathrm{Ma}$, suggested by Lacassin et al. [2004], Valli et al. [2007, 2008], Rolland et al. [2009], and Leloup et al. [2011] are based on the interpretation that $\sim 23$ Ma granites found along the Karakoram fault are synkinematic and the result of shear 

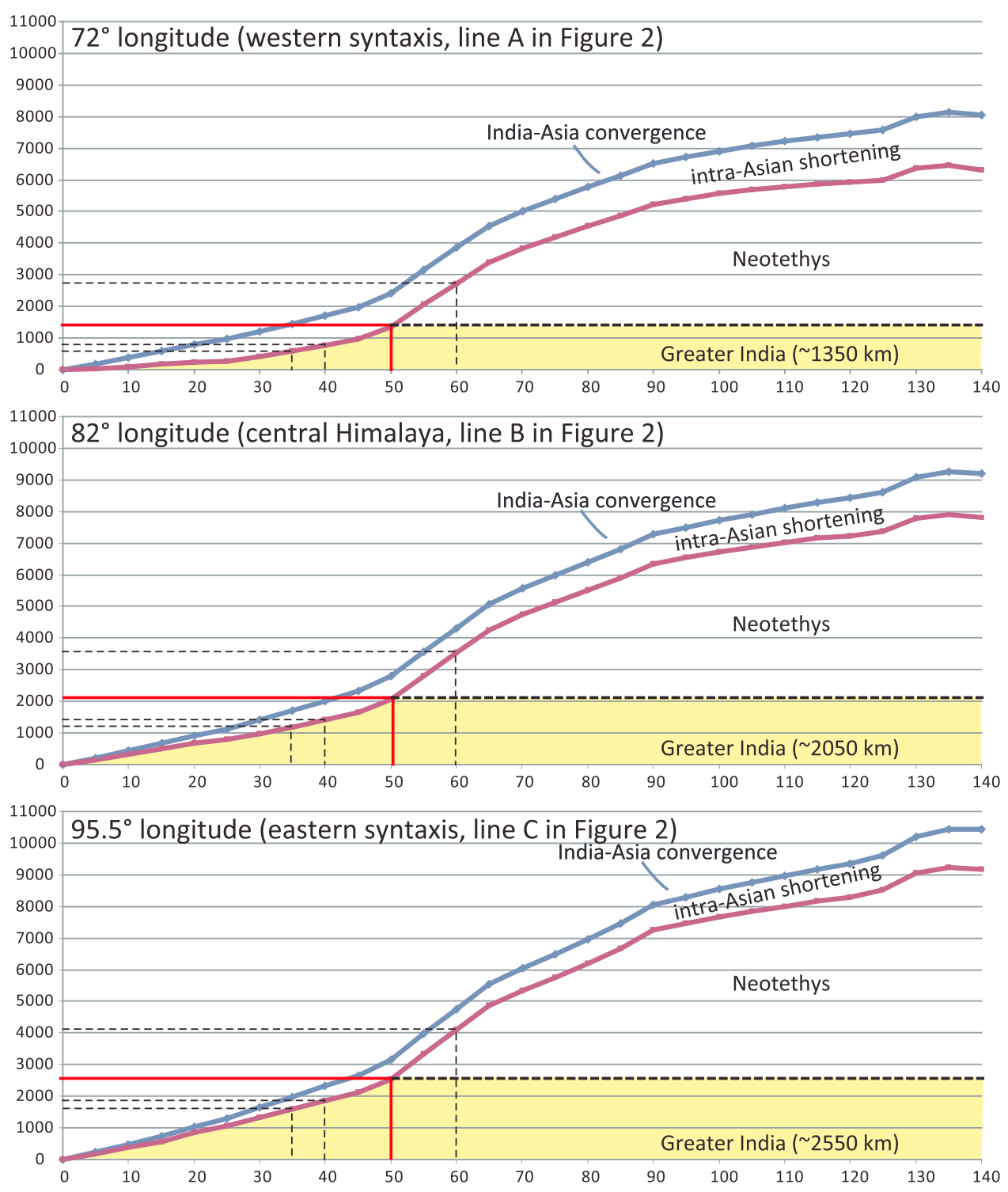

Figure 6. Graphs illustrating the size of Greater India as a function of collision age, using the restoration of intra-Asian shortening as reconstructed in this paper. Our preferred size assumes a 50 Ma collision age, but alternative scenarios with ages of 35, 40 and $60 \mathrm{Ma}$ are also indicated. Even the youngest proposed collision age still requires a size of Greater India that is up to 3 times larger than the amount of shortening recorded in the Himalaya. This suggests that a large portion of Greater India subducted entirely without accretion, that a substantial amount of Greater Indian upper crust is duplexed beneath Tibet, or both.

heating along the Karakoram fault. This mechanism for granite batholith emplacement is disputed, however, by, e.g., Searle and Phillips [2007]. We note that a 23 Ma onset of the Karakoram fault would require that either the ATF was not active between $\sim 25$ and $\sim 13 \mathrm{Ma}$, or that the Karakoram Fault was associated with an NE-SW extensional component, or that the Karakoram Fault was offset by the Karakax fault. All of these options are challenged by geological evidence. We therefore apply a $13 \mathrm{Ma}$ age for onset of the Karakoram fault in our reconstruction, and reconstruct up to $\sim 100 \mathrm{~km}$ of displacement along the central ATF since this time, with the remaining $300 \mathrm{~km}$ between 30 and $13 \mathrm{Ma}$.

\subsection{Tibetan Shortening and the Amount of Karakoram Fault Offset}

[61] The Karakoram fault transfers shortening in the Rushan-Pshart fold-and-thrust belt at its northwestern termination [Robinson et al., 2004], to shortening absorbed in the Lesser Himalaya and around the IYSZ at its southeastern termination. Approximately $65 \mathrm{~km}$ of displacement of the Karakoram fault is transferred into the Gurla-Mandhata core complex, and from there it is probably transferred to the Main Boundary Thrust [Murphy and Copeland, 2005]. The Great Counter Thrust is the only recognized structure that could have absorbed the remainder of Karakoram fault displacement (Figure 8). 

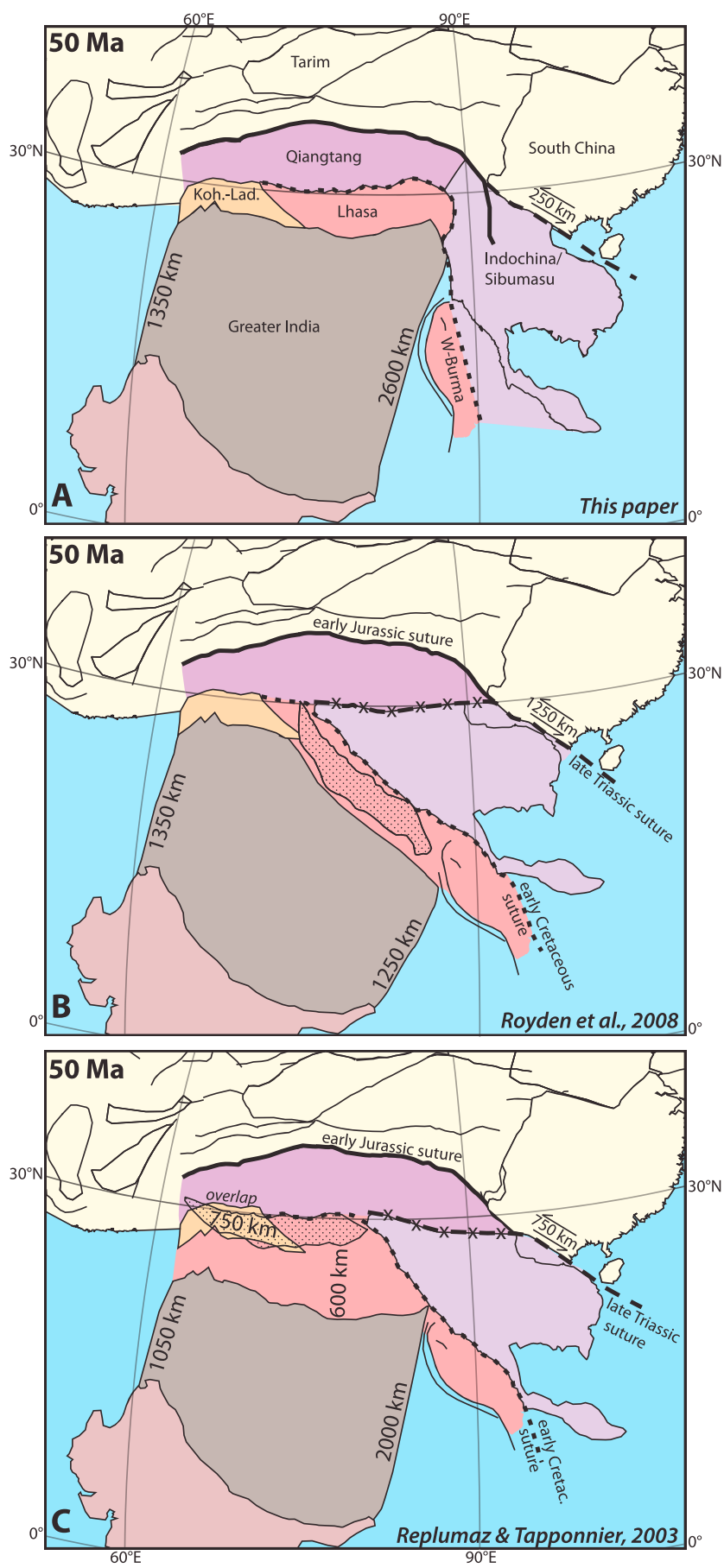

Figure 7. Reconstructions of Greater Asia (a) following this paper; (b) using the reconstruction of Asia in this paper but including $\sim 1250 \mathrm{~km}$ of Indochina extrusion from between the Lhasa and Qiangtang terranes similar to those of Royden et al. [2008] and (c) same as Figure 7b but including $\sim 750 \mathrm{~km}$ of Indochina extrusion similar to that of Replumaz and Tapponnier [2003].

[62] Approximately $16 \mathrm{~km}$ of shortening between 18 and $11 \mathrm{Ma}$ have been documented along the Great Counter Thrust [Yin et al., 1999a; Murphy and Yin, 2003; Murphy et al., 2009]. The low total displacement end-member sce- nario for Karakoram fault, with offsets of up to $150 \mathrm{~km}$, requires $\sim 70 \mathrm{~km}$ of $\mathrm{N}-\mathrm{S}$ shortening along the Great Counter thrust system. Although we reconstructed this amount of shortening, we note that this displacement is nearly five times as much as documented. Searle and Phillips [2007] suggested that the displacement along the Karakoram fault may even be much smaller than $150 \mathrm{~km}$, which would resolve this discrepancy. Thus, we thus interpret the amount of displacement along the Karakoram Fault and the associated amount of shortening in the Rushan-Pshart fold-and-thrust belt and the Great Counter Thrust in our reconstruction as a maximum estimate. There is no geological evidence for the hundreds kilometers of Neogene shortening in southern Tibet required by much higher estimates of 300-600 km of Karakoram Fault displacement of Lacassin et al. [2004], Valli et al. [2007, 2008] and Rolland et al. [2009].

\subsection{Restoring Southward Subduction Along the Main Pamir Thrust}

[63] The total amount of N-S convergence accommodated along the Main Pamir Thrust is estimated from the dextral displacement along the KYTS $(\sim 270 \mathrm{~km})$ and the $\sim 100 \mathrm{~km}$ of Cenozoic shortening of the Western Kunlun Shan [Cowgill, 2001]. The amount of convergence accommodated along the Main Pamir Thrust is thus $\sim 370 \mathrm{~km}$. This estimate is consistent with the $300-350 \mathrm{~km}$ of subduction below the Pamir estimated from seismic tomographic images [e.g., Negredo et al., 2007] and the Benioff zone below the Pamir to $\sim 300 \mathrm{~km}$ depth [e.g., Pegler and Das, 1998; Pavlis and Das, 2000].

\subsection{The Extrusion of Indochina: Small Versus Large Displacement Along the RRF}

[64] The estimates for the amount of $\sim 30-20 \mathrm{Ma}$ (or slightly younger) sinistral displacement along the RRF vary from $250 \mathrm{~km}$ [Hall et al., 2008; Fyhn et al., 2009] to $700 \pm$ $200 \mathrm{~km}$ [Leloup et al., 1995]. Royden et al. [2008] inferred this displacement to be as large as $\sim 1250 \mathrm{~km}$. In this section, we first attempt to reconcile the minimum amount of RRF displacement with the geology of Tibet. We will then test whether large displacements are consistent with regional kinematic constraints. To accommodate the minimum displacement, we reconstruct an $\sim 200-250 \mathrm{~km} \sim \mathrm{E}-\mathrm{W}$ shortening component of the Qiangtang and Lhasa terranes in the Yunnan region between the eastern Himalayan syntaxis and the South China block, while the RRF is active as sinistral shear zone. Because N-S shortening was simultaneously active in Tibet. This style of deformation is consistent with the narrow, N-S trending geometry of the Lhasa and Qiangtang terranes, the consistently large clockwise rotations in this region, and the Oligocene dextral strike-slip component in the Gaoligong shear zone (Figure 9 and Table 1).

[65] Restoring Sundaland $250 \mathrm{~km}$ to the NW in OligoceneMiocene time generates overlap between the West Burma Block (see section 4.7) and (Greater) India. This overlap can be avoided by reconstructing a clockwise vertical axis rotation of mainland Sundaland. The minimum angle over which we have to rotate mainland Sundaland (around a pole on the $\mathrm{RRF}$, see below) to avoid a west Burma-India overlap is $13^{\circ}$ clockwise. This rotation is consistent with paleomagnetic estimates of $10-20^{\circ}$ of clockwise rotation [Huang and Opdyke, 1993; Charusiri et al., 2006; Aihara et al., 2007; 

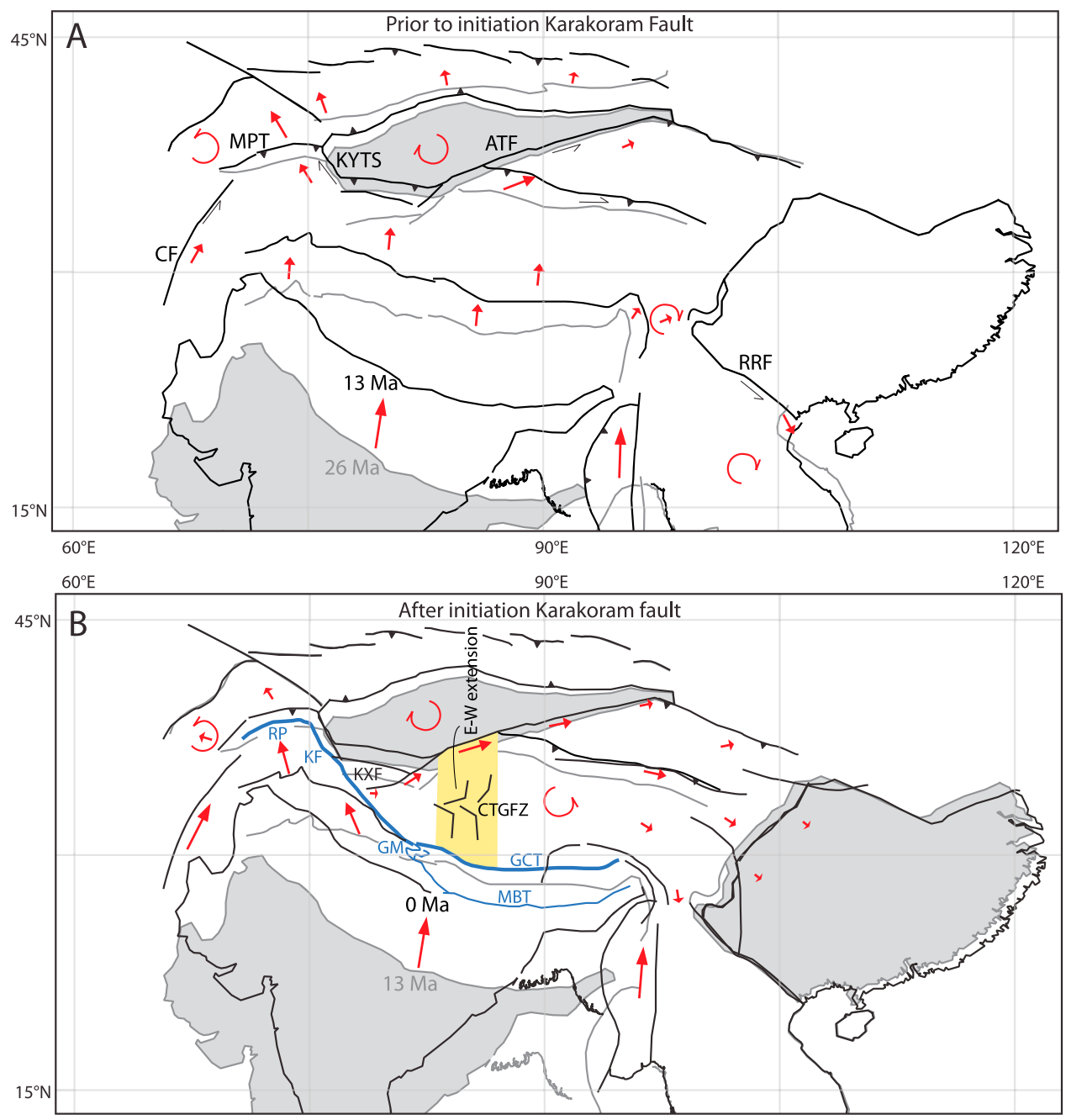

Figure 8. Kinematic evolution of the Tibetan Plateau. (a) Prior to the existence of the Karakoram Fault (26-13 Ma), the Tarim basin acted as a rigid indenter with motion to the NNW in the Pamir and ENE in the NE Tibet. We postulate a dextral fault, or distributed shear zone, along the southern edge of NE Tibet to accommodate the eastward motion component with respect to central Tibet. (b) The Karakoram Fault (13-0 Ma) and its terminations are indicated in blue. To the NW, dextral slip of the Karakoram Fault is accommodated in the Rushan Pshart region, whereas in the SE it is transferred first to the Great Counter Thrust (until $\sim 10 \mathrm{Ma}$ ) and then the Main Boundary Thrust via the Gurla Mandhata core complex [Murphy et al., 2000; Murphy and Copeland, 2005]. The Karakoram Fault prevents motion of western Tibet with respect to Tarim: the Karakax Fault is sealed by the Karakoram Fault. Coeval motion of the Altyn Tagh Fault can only occur through a counterclockwise rotation of Tibet about a pole at the Karakoram Fault, in combination with E-W extension in the segment south of the central Altyn Tagh Fault.

Takemoto et al., 2009]. The rotation pole is estimated based on the distribution of transpression and transtension along the RRF. Several authors have argued for a transtensional component in the central and southeastern part of the RRF [Leloup et al., 1995, 2001; Harrison et al., 1996]. We restore a N-S extensional component for the SE part of the RRF of up to $50 \mathrm{~km}$, superimposed on the $250 \mathrm{~km}$ of translation, and a maximum $\sim 150 \mathrm{~km} \sim \mathrm{N}-\mathrm{S}$ shortening component in the northwest. Transpression is partitioned over the Shan Thai deformed belt south of the RRF, consistent with the large, and locally varying clockwise rotations measured there [e.g., Yang et al., 1995; Aihara et al., 2007; Sato et al., 2007;
Tanaka et al., 2008]. We conclude that a displacement of $250 \mathrm{~km}$ along the RRF gives predictions for eastern Tibetan tectonics that are consistent with the available constraints.

[66] The larger displacements of $\sim 750$ [Replumaz and Tapponnier, 2003] or $\sim 1250 \mathrm{~km}$ [Royden et al., 2008] (Figure 7) predict several regional geometries and configurations that appear inconsistent with geological observations.

[67] 1. Both scenarios assume a NW-SE striking strikeslip fault across the Three Rivers region that connects the RRF with the hypothetical Karakoram-Jiali strike-slip fault. Left-lateral displacement on this hypothetical fault must 
equal to the amount of extrusion (750 km or more). Such a fault remains to be documented.

[68] 2. The Karakoram-Jiali strike-slip fault would run along the Bangong-Nujiang suture. This region is wellstudied and is characterized by a Cretaceous fold-thrust belt that underwent only minor thrust reactivation in the critical time interval of 30-20 Ma [Kapp et al., 2007a]. These observations are clearly at odds with the prediction of major Oligocene strike-slip. Post-20 Ma strike-slip faults in this region has displacements of less than $20 \mathrm{~km}$ [Taylor et al., 2003].

[69] 3. The model of Replumaz and Tapponnier [2003] restores the Lhasa block $\sim 700 \mathrm{~km}$ westward, which would require $700 \mathrm{~km}$ of $\mathrm{E}-\mathrm{W}$ extension. This extension would need to accumulate either along the Karakoram Fault or in the Pamir-Hindu Kush depending on the assumed onset age of the Karakoram Fault. There is no evidence for substantial E-W extension in Tibet or the Pamir prior to $13 \mathrm{Ma}$.

[70] 4. Sundaland is much wider than the Lhasa terrane. Thus, the extrusion scenario predicts that the Lhasa terrane accumulated $\sim 600 \mathrm{~km}$ Oligocene-early Miocene N-S shortening by [Replumaz and Tapponnier, 2003]. Thick piles of flat lying to gently dipping upper Cretaceous to Eocene volcanics units throughout the Lhasa terrane [P. Kapp et al., 2005, 2007a; Ding et al., 2007; Lee et al., 2009; Pullen et al., 2011; Zhu et al., 2011], as well as balanced cross sections from the region [Kapp et al., 2007b], preclude this shortening history. Royden et al. [2008] predict $\sim 40^{\circ}$ counterclockwise rotation of the Lhasa block. Paleomagnetic evidence from the southern Lhasa block, however, suggests minimal vertical axis rotation of this region since the Cretaceous [Tan et al., 2010; Dupont-Nivet et al., 2010a].

[71] 5. Royden et al. [2008] suggest diachronous eastward motion of the Indochina block, resulting in a "collision" between Lhasa and Qiangtang during the Cenozoic extrusion. Folding and thrusting across the Bangong-Nujiang suture, however is largely pre-Cenozoic in age $[P$. Kapp et al., 2005].

[72] 6. All extrusion models restore the Indochina block south of the Qiangtang terrane [Lee and Lawver, 1995; Replumaz and Tapponnier, 2003; Royden et al., 2008]. The Indochina-South China suture, however, is of middle-late Triassic age [Ferrari et al., 2008; Cai and Zhang, 2009] and predates the upper Triassic-lower Jurassic Jinsha suture north of the Qiangtang block [Yin and Harrison, 2000]. The Indochina-South China suture certainly is not equivalent to the lower Cretaceous Bangong-Nujiang suture [Dewey et al., 1988; Yin and Harrison, 2000; Kapp et al., 2007a]. Thus, a palinspastic position of Indochina south of the Qiangtang block (Figure 7) is inconsistent with the suture ages.

[73] We thus conclude that a position of the Indochina block as far west as central Tibet, as required by $750 \mathrm{~km}$ or more of displacement of the RRF, is inconsistent with geological observations. We note, however, that we have probably underestimated the amount of shortening in eastern Tibet and therefore cannot exclude that the amount of extrusion was (slightly) higher than the $250 \mathrm{~km}$ postulated by Hall et al. [2008]. Additional structural geological data from eastern Tibet, as well as vertical axis rotation patterns of the eastern Lhasa terrane, could help resolve the kinematic evolution of this part of the collision zone.

\subsection{Paleomagnetic Constraints on SE Asian Motion?}

[74] On first glance, the paleomagnetic interpretations of southward motion of Indochina of $7-14^{\circ}$ seem to support major displacement along the RRF [Yang and Besse, 1993; Yang et al., 1995, 2001; Sato et al., 1999, 2001, 2007; Chi and Dorobek, 2004; Takemoto et al., 2005]. Upon closer inspection, however, these data sets are mutually inconsistent and suggest an amount of southward translation that cannot be reconciled with known geological constraints.

[75] First, all these paleomagnetic data sets were obtained from red beds, which are known to be biased by compaction-induced swallowing of paleomagnetic inclinations, leading to underestimates of paleolatitude [e.g., King, 1955; Tan and Kodama, 2002; Tauxe, 2005; Tauxe et al., 2008]. None of the studies from Sundaland have been evaluated for inclination shallowing. Typical flattening factors of 0.6 would increase the southward translation suggested by the data sets to $10-20^{\circ}$, or $1100-2200 \mathrm{~km}$. This is much more than the $450 \mathrm{~km}\left(\sim 4^{\circ}\right)$ of southward motion associated with the largest RRF displacement estimate of $900 \mathrm{~km}$ [Leloup et al., 1995]. Even if we assume no inclination flattening, the $770-1500 \mathrm{~km}$ of paleomagnetically inferred southward motion would place Indochina at the latitude of the Tarim basin. This is clearly inconsistent with the geological evidence.

[76] Second, there are inconsistencies among the data sets. Takemoto et al. [2005] reported results from the Son Da region to the south of the RRF, which indicate no southward motion with respect to South China, and suggested that extrusion was accommodated along a fault to the south of the RRF. Liu and Morinaga [1999] also concluded that the RRF did not accommodate extrusion because their data suggest southward translations of $8-14^{\circ}$ of blocks to the north of the RRF. Tanaka et al. [2008] argued for southward translation of Indochina along the RRF, but prior to $32 \mathrm{Ma}$, i.e., prior to the demonstrated existence of this fault. Instead of southward motion Richter and Fuller [1996] reported $\sim 5^{\circ}$ northward motion of the Shan plateau in Myanmar, east of the Sagaing Fault. The reasons for these inconsistencies remain elusive, but at this stage we do not take these data into account.

\subsection{Restoration of the West Burma Block and the Three Pagodas and Mae Ping Faults}

[77] We reconstructed a $13^{\circ}$ clockwise rotation of Sundaland between 30 and $20 \mathrm{Ma}$. This avoids an overlap between Greater India and the West Burma Block in that time period. A reconstruction of the West Burma Block with respect to India and Sundaland that follows the available constraints and avoids overlaps, however, requires additional corrections.

[78] The available constraints (Table 1 and Figure 3) include (1) $530 \mathrm{~km}$ of displacement along the Sagaing Fault since $11 \mathrm{Ma}$; (2) right-lateral motion along the Shan Scarp and Mogok Belt in the Oligocene to Early Miocene; (3) $100 \mathrm{~km}$ of displacement on both the Three Pagodas and Mae Ping faults between $\sim 40$ and $23 \mathrm{Ma}$ and (4) at least $300 \mathrm{~km}$ of eastward subduction of India below the West Burma Block [Van der Voo et al., 1999a; Li et al., 2008].

[79] There are two geometrical arguments why northward displacement of the West Burma Block was not restricted to 

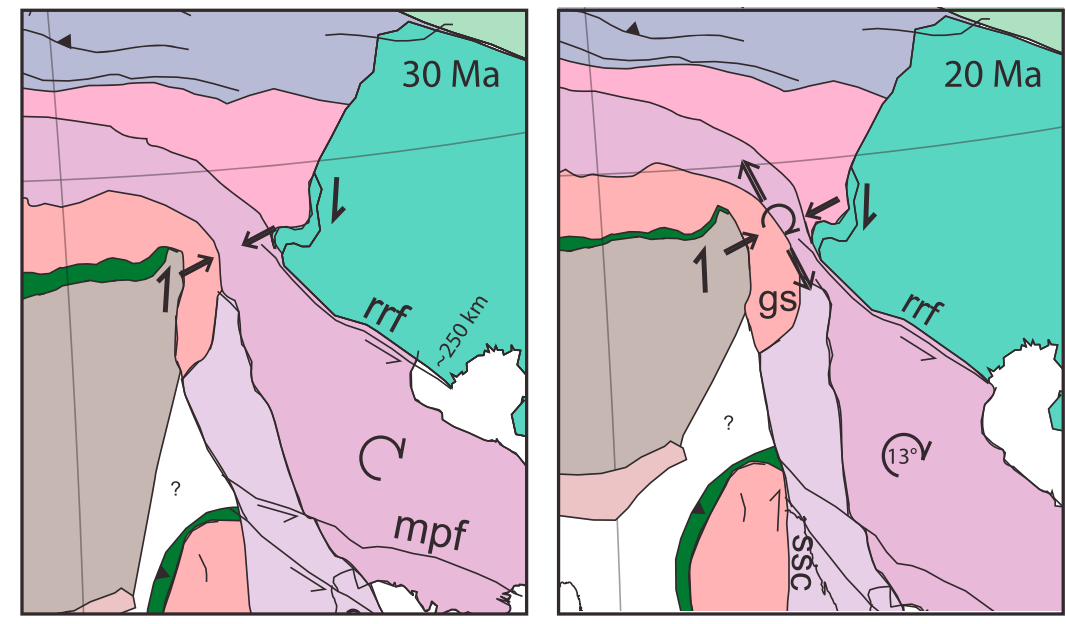

Figure 9. Snapshots from the reconstruction at 30 and $20 \mathrm{Ma}$, showing how extrusion of Indochina from eastern Tibet has been reconciled. Approximately $250 \mathrm{~km}$ of extrusion [Hall et al., 2008; Fyhn et al., 2009] can be accommodated by dextral transpression between Tibet and Indochina. There is no evidence for Oligocene-early Miocene faults connecting the NW termination of the RRF with faults in Tibet, or significant offset between the Lhasa and Qiangtang terranes in SE Tibet. More displacement along the RRF would place Indochina south of the Bangong-Nujiang suture, or would require $\sim 500 \mathrm{~km}$ of shortening in the central and western Lhasa terrane. Neither of these scenarios are consistent with the known geology of the region (see text for discussion), and we conclude that displacements along the RRF cannot be substantially larger than suggested by Hall et al. [2008] and Fyhn et al. [2009] are at odds with geological constraints of Tibet. See text for further discussion. See Figure 2 for legend.

$530 \mathrm{~km}$ of post-11 Ma displacement (Table 1 and Figure 3). First, leaving the West Burma Block in its 11 Ma position leads to overlap between the West Burma Block and the Shillong Plateau prior to $11 \mathrm{Ma}$. The Shillong Plateau has an unmetamorphosed Mesozoic and younger cover, and there is no evidence that this plateau was disconnected from the Indian continent prior to its late Miocene and younger deformation [Clark and Bilham, 2008]. Therefore, the West Burma Block cannot have a position that overlaps with the pathway of the Shillong Plateau with respect to Sundaland. Second, the 11 Ma position of the West Burma Block brings its central part due west of the western terminations of the Mae Ping and Three Pagodas faults. Each of these faults has $100-160 \mathrm{~km}$ of left-lateral displacement between 40 and $23 \mathrm{Ma}$ (Table 1). There is no evidence for equivalents of the Three Pagodas or Mae Ping faults crosscutting the West Burma Block, which must therefore have been south of the Three Pagodas Fault until at least $\sim 23 \mathrm{Ma}$ ago. Morley [2004] suggested that the Shan Scarp is connected to the Three Pagodas fault. This configuration, however, requires a major Miocene displacement along the Three Pagodas fault to avoid overlap between the Shillong Plateau and the West Burma Block. The pre-23 Ma age and only $100-160 \mathrm{~km}$ displacement of the Three Pagodas fault (Table 1 and Figure 3) seem to preclude this scenario.

[80] Bringing the northern edge of the West Burma Block south of the northwestern termination of the Three Pagodas Fault requires a northward motion of the West Burma Block that equates to India's northward motion since $23 \mathrm{Ma}(\sim 600 \mathrm{~km})$. This age coincides with the end of activity of the Three Pagodas Fault [Fyhn et al., 2010a], and prevents overlap between the West Burma Block and the Shillong Plateau pathway. Partitioning of oblique IndiaIndochina motion through strike-slip along the Shan Scarp and subsequently to the Sagaing fault generates $350 \mathrm{~km}$ of eastward subduction of India below the West Burma Block. This prediction is consistent with seismic tomographic interpretations [Van der Voo et al., 1999a; Li et al., 2008].

[81] In summary, to fulfill all constraints on the motion of west Burma with respect to India and Sundaland, we reconstruct a large $(\sim 650 \mathrm{~km})$ displacement along the Shan Scarp between 23 and $11 \mathrm{Ma}$, and assume continuity of the Shan Scarp offshore to NW Sumatra. Prior to $23 \mathrm{Ma}$, we couple the West Burma Block with southern Sibumasu, and restore a minimum sinistral displacement of $100 \mathrm{~km}$ from 40 to $23 \mathrm{Ma}$ for both the Mae Ping and Three Pagodas faults (Table 1).

\section{Discussion: The Size of Greater India as a Function of Collision Age}

[82] Our restoration of intra-Asian shortening has direct implications for the amount of Indian plate lithosphere that subducted after the initial Tethyan Himalaya-Lhasa collision. Different proposals exist for the age of this collision, varying from $\sim 65 \mathrm{Ma}$ [e.g., Cai et al., 2011] to $\sim 35 \mathrm{Ma}$ [Aitchison et al., 2007, 2011]. Most authors prefer an age between 55 and $50 \mathrm{Ma}$ [e.g., Zhu et al., 2005; Green et al., 2008; Najman et al., 2010; Wang et al., 2011]. The arguments for the collision age have been recently reviewed by van Hinsbergen et al. [2011], and we follow their preference for a $\sim 50$ Ma collision age in the reconstructions shown in Figures 4,5 , and 7 . We note, however, that our restoration is independent from the collision age and can be used to determine the size of Greater India as a function of collision age, as shown for three reference sections in Figures 2 and 6. The curves in Figure 6 show the amount of India-Asia convergence measured along great circles in $5 \mathrm{Ma}$ intervals, 
using the plate circuit of van Hinsbergen et al. [2011] and the intra-Asian shortening through time reconstructed in this paper. Uncertainties in the convergence estimates are on the order of $100-200 \mathrm{~km}$. For illustration, we have indicated the minimum and maximum proposed collision ages, as well as our preferred collision age.

[83] A $\sim 50$ Ma collision requires that the size of Greater India was 1350, 2060 and $2600 \mathrm{~km}$ wide for our three reference points from west to east, respectively, at the time of initial collision (Figure 6). This size of Greater India is much larger than reconstructed fits with the western Australian margin in early Cretaceous and older time [Ali and Aitchison, 2005]. It is consistent, however, with paleogeographic reconstructions based on independent, high-quality paleomagnetic poles from $\sim 70$ and $\sim 60$ Ma old sediments from the Tethyan Himalaya [Patzelt et al., 1996] corrected for inclination swallowing due to sedimentation and compaction [Dupont-Nivet et al., 2010b]. These Tethyan Himalayan poles show $17 \pm 4^{\circ}$ of paleolatitudinal separation (i.e., $1900 \pm$ $450 \mathrm{~km}$ ) between the Tethyan Himalaya and India [DupontNivet et al., 2010b].

[84] A collision younger than $50 \mathrm{Ma}$ would decrease the required size of Greater India. A 35 Ma collision age would, however, still require that Greater India was $\sim 1200 \mathrm{~km}$ and $\sim 1600 \mathrm{~km}$ wide in the central and eastern part of the collision zone. An older collision age of $\sim 65$ Ma would increase the size of Greater India to as much as $4000 \mathrm{~km}$ (Figure 6).

[85] The Himalaya consist of rocks that were scraped off of Indian plate continental crust during post-50 Ma subduction and underthrusting. Eight balanced cross-sections across the Himalaya, i.e., the geological record of Greater India [Hodges, 2000], at longitudes from the western to eastern Himalayan syntaxes [see DeCelles et al., 2002; Long et al., 2011, and references therein] show that the currently $\sim 275 \mathrm{~km}$ wide Himalaya was shortened by $\sim 450$ to $\sim 650 \mathrm{~km}$. One cross section from western Nepal [Robinson et al., 2006] shows as much as $900 \mathrm{~km}$ of shortening. The amount of shortening in the Himalaya is thus much less than the early Eocene size of Greater India determined paleomagnetically [Patzelt et al., 1996], as well as suggested by our reconstruction of Greater Asia. It therefore seems likely that the amount of shortening in the Himalaya significantly underestimates the amount of subduction of the Indian Plate since collision. This may in part be the result of erosion in the Himalaya, or structural burial and duplexing of Greater Indian upper crust below Tibet [Hacker et al., 2005; Nábělek et al., 2009]. In addition, or alternatively, one may speculate that a large portion of Greater India consisted of thinned continental, or even oceanic crust [DupontNivet et al., 2010a]. Additional studies in the Himalaya are needed to test this inference, which would require substantial revision to our understanding of where and how Cenozoic convergence was accommodated between India and Asia.

\section{Conclusions}

[86] We review recent kinematic constraints from the Tibetan Plateau, the Pamir-Hindu Kush region, the Tien Shan, Mongolia, southern Siberia, Sundaland, and the West Burma Block to provide an updated estimate of the amount of India-Asia convergence that was accommodated by shortening and extrusion in the overriding plate since $50 \mathrm{Ma}$.
Reconciling all independent kinematic constraints shows that at the longitude of the western Himalayan syntaxis $\left(\sim 72^{\circ} \mathrm{E}\right)$, $\sim 1050 \mathrm{~km}$ of intra-Asian shortening occurred. At longitude of the western Tibetan Plateau $\left(\sim 82^{\circ} \mathrm{E}\right), \sim 750 \mathrm{~km}$ of $\mathrm{N}-\mathrm{S}$ shortening occurred since $50 \mathrm{Ma}$, decreasing to $\sim 600 \mathrm{~km}$ in eastern Tibet $\left(\sim 95^{\circ} \mathrm{E}\right)$, with the largest uncertainty in the eastern Tibetan segment.

[87] Approximately $250 \mathrm{~km}$ of SE-ward extrusion of Sundaland along the Red River Fault, as predicted by palinspastic reconstructions of SE Asia, can be straightforwardly reconciled with dextral transpression in SE Tibet. Our estimates for Cenozoic intra-Asian shortening and extrusion are lower than in previous reconstructions of the collision zone, which predicted as much as $2000 \mathrm{~km}$ of intra-Asian shortening and $750-1250 \mathrm{~km}$ or more Sundaland extrusion. We conclude that such large values are inconsistent with geological evidence from Tibet. It remains possible that the amount of extrusion exceeded $250 \mathrm{~km}$, but probably not by much. Future kinematic work in eastern Tibet is required to assess this possibility.

[88] Combining our intra-Asian shortening reconstruction with the Indo-Atlantic plate circuit allows us to estimate the size of Greater India as a function of the Tethyan HimalayaLhasa collision age. Estimates for this age vary from $\sim 65$ to $\sim 35 \mathrm{Ma}$. Even for the youngest collision age, the required size of Greater India is up to 3 times larger than the amount of shortening recorded in the Himalaya. This suggests that a significant portion of Greater India subducted without accretion of its upper crust, or with its upper crust duplexed below the Tibetan Plateau.

[89] Acknowledgments. A large number of colleagues have helped with advice and discussion during this project. We thank Marc Jolivet and an anonymous reviewer for their valuable comments. Mike Searle patiently answered several long e-mails, and Nadine McQuarrie, Sean Long, Torgeir Andersen and Pavel Doubrovine are thanked for discussion. D.J.J.v.H. and T.H.T. acknowledge financial support from Statoil (SPlates project) and the Center for Advanced Study of the Norwegian Academy of Sciences. G.D.-N. acknowledges support from the Netherland's organization for scientific research (NWO-ALW). P.K., P.C.L. and P.G.D. acknowledge support from the U.S. NSF Tectonics Program.

\section{References}

Acharya, S. K., and N. D. Mitra (1986), Regional geology and tectonic setting of northeast India and adjoining region, in Geology of Nagaland Ophiolite, Mem. Geol. Surv. India, vol. 119, pp. 6-12, Geol. Surv. of India, Kolkata, India.

Aihara, K., et al. (2007), Internal deformation of the Shan-Thai block inferred from paleomagnetism of Jurassic sedimentary rocks in northern Thailand, J. Asian Earth Sci., 30, 530-541, doi:10.1016/j.jseaes. 2007.01.002.

Aitchison, J. C., J. R. Ali, and A. M. Davis (2007), When and where did India and Asia collide?, J. Geophys. Res., 112, B05423, doi:10.1029/ 2006JB004706.

Aitchison, J., X. Xia, A. T. Baxter, and J. R. Ali (2011), Detrital zircon U-Pb ages along the Yarlung-Tsangpo suture zone, Tibet: Implications for oblique convergence and collision between India and Asia, Gondwana Res., doi:10.1016/j.gr.2011.04.002, in press.

Alexeiev, D. V., H. E. Cook, V. M. Buvtyshkin, and L. Y. Golub (2009), Structural evolution of the Ural-Tian Shan junction: A view from Karatau ridge, south Kazakhstan, C. R. Geosci., 341, 287-297, doi:10.1016/j. crte.2008.12.004.

Ali, J. R., and J. C. Aitchison (2005), Greater India, Earth Sci. Rev., 72, 169-188, doi:10.1016/j.earscirev.2005.07.005.

Allen, C. R., Z. Luo, H. Qian, X. Wen, H. Zhou, and W. Huang (1991), Field study of a highly active fault zone: The Xianshuihe fault of southwestern China, Geol. Soc. Am. Bull., 103, 1178-1199, doi:10.1130/00167606(1991)103<1178:FSOAHA>2.3.CO;2. 
Allen, M. B., B. F. Windley, and C. Zhang (1993), Palaeozoic collisional tectonics and magmatism of the Chinese Tien Shan, central Asia, Tectonophysics, 220, 89-115, doi:10.1016/0040-1951(93)90225-9.

Allen, M. B., G. I. Alsop, and V. G. Zhemchuzhnikov (2001), Dome and basin refolding and transpressive inversion along the Karatau Fault System, southern Kazakhstan, J. Geol. Soc., 158, 83-95, doi:10.1144/ jgs.158.1.83.

Allmendinger, R. W., R. Reilinger, and J. Loveless (2007), Strain and rotation rate from GPS in Tibet, Anatolia and the Altiplano, Tectonics, 26 , TC3013, doi:10.1029/2006TC002030.

Armijo, R., P. Tapponnier, J. L. Mercier, and H. Tong-Lin (1986), Quaternary extension in southern Tibet: Field observations and tectonic implications, J. Geophys. Res., 91, 13,803-13,872, doi:10.1029/ JB091iB14p13803.

Armijo, R., P. Tapponnier, and H. Tonglin (1989), Late Cenozoic rightlateral strike-slip faulting in southern Tibet, J. Geophys. Res., 94 2787-2838, doi:10.1029/JB094iB03p02787.

Arzhannikova, A., S. Arzhannikov, M. Jolivet, R. Vassallo, and A Chauvet (2011), Pliocene to Quaternary deformation in South East Sayan (Siberia): Initiation of the Tertiary compressive phase in the southern termination of the Baikal Rift System, J. Asian Earth Sci., 40, 581-594, doi:10.1016/j.jseaes.2010.10.011

Avouac, J.-P., and P. Tapponnier (1993), Kinematic model of active deformation in central Asia, Geophys. Res. Lett., 20, 895-898, doi:10.1029/ 93GL00128

Avouac, J.-P., P. Tapponnier, M. Bai, H. You, and G. Wang (1993), Active thrusting and folding along the northern Tien Shan and Late Cenozoic rotation of the Tarim relative to Dzungaria and Kazakhstan, J. Geophys. Res., 98, 6755-6804, doi:10.1029/92JB01963.

Barber, A. J., and M. J. Crow (2009), Structure of Sumatra and its implications for the tectonic assembly of Southeast Asia and the destruction of Paleotethys, Isl. Arc, 18, 3-20, doi:10.1111/j.1440-1738.2008.00631.x.

Barley, M. E., A. L. Pickard, K. Zaw, P. Rak, and M. G. Doyle (2003), Jurassic to Miocene magmatism and metamorphism in the Mogok metamorphic belt and the India-Eurasia collision in Myanmar, Tectonics, 22(3), 1019, doi:10.1029/2002TC001398

Bazhenov, M. L., H. Perroud, A. Chauvin, V. S. Burtman, and J.-C Thomas (1994), Paleomagnetism of Cretaceous red beds from Tadzhikistan and Cenozoic deformation due to India-Eurasia collision, Earth Planet. Sci. Lett., 124, 1-18, doi:10.1016/0012-821X(94)00072-7.

Bertrand, G., and C. Rangin (2003), Tectonics of the western margin of the Shan plateau (central Myanmar): Implication for the India-Indochina oblique convergence since the Oligocene, J. Asian Earth Sci., 21, 1139-1157, doi:10.1016/S1367-9120(02)00183-9.

Bertrand, G., C. Rangin, H. Maluski, H. Bellon, and GIAC-Scientific Party (2001), Diachronous cooling along the Mogok Metamorphic Belt (Shan scarp, Myanmar): The trace of the northward migration of the Indian syntaxis, J. Asian Earth Sci., 19, 649-659, doi:10.1016/S1367-9120(00) $00061-4$

Bhutani, R., K. Pande, and T. R. Venkatesan (2009), ${ }^{40} \mathrm{Ar}-{ }^{39} \mathrm{Ar}$ dating of volcanic rocks of the Shyok suture zone in north-west trans-Himalaya: Implications for the post-collision evolution of the Shyok suture zone, J. Asian Earth Sci., 34, 168-177, doi:10.1016/j.jseaes.2008.03.013.

Blisniuk, P. M., B. R. Hacker, J. Glodny, L. Ratschbacher, S. Bi, Z. Wu, M. O. McWilliams, and A. Calvert (2001), Normal faulting in central Tibet since at least 13.5 Myr ago, Nature, 412, 628-632, doi:10.1038/ 35088045 .

Bourgeois, O., P. R. Cobbold, D. Rouby, J.-C. Thomas, and V. Shein (1997), Least squares restoration of Tertiary thrust sheets in map view, Tajik depression, central Asia, J. Geophys. Res., 102, 27,553-27,573, doi:10.1029/97JB02477.

Boyden, J. R., R. D. Müller, M. Gurnis, T. H. Torsvik, J. Clark, M. Turner H. Ivey-Law, R. Watson, and J. Cannon (2010), Next-generation platetectonic reconstructions using GPlates, in Geoinformatics, edited by R. Keller and C. Baru, pp. 95-113, Cambridge Univ. Press, Cambridge, U. K.

Briais, A., P. Patriat, and P. Tapponnier (1993), Updated interpretation of magnetic anomalies and seafloor spreading stages in the South China Sea: Implications for the Tertiary tectonics of Southeast Asia, J. Geophys. Res., 98, 6299-6328, doi:10.1029/92JB02280.

Brunnschweiler, R. O. (1966), On the geology of the Indoburman Ranges (Arakan Coast and Yoma, Chin Hills, Naga Hills), J. Geol. Soc. Aust., 13, 137-194.

Bullen, M. E., D. W. Burbank, and J. I. Garver (2003), Building the northern Tien Shan: Integrated thermal, structural, and topographic constraints, J. Geol., 111, 149-165, doi:10.1086/345840.

Burbank, D. W., J. K. McLean, M. E. Bullen, K. Y. Abdrakhmatov, and M. M. Miller (1999), Partitioning of intermontane basins by thrust- related folding, Tien Shan, Kyrgyzstan, Basin Res., 11, 75-92, doi:10.1046/j.1365-2117.1999.00086.x

Burchfiel, B. C., Z. Chen, L. H. Royden, Y. Liu, and C. Deng (1991), Extensional development of Gabo Valley, southern Tibet, Tectonophysics, 194, 187-193, doi:10.1016/0040-1951(91)90283-X

Burchfiel, B. C., L. H. Royden, R. D. van der Hilst, B. H. Hager, Z. Chen, R. W. King, C. Li, J. Lü, H. Yao, and E. Kirby (2008), A geological and geophysical context for the Wenchuan earthquake of 12 May 2008, Sichuan, People's Republic of China, GSA Today, 18(7), doi:10.1130/ GSATG18A.1.

Burtman, V. S. (1975), Structural geology of the Variscan Tien Shan, Am. J. Sci., 275A, 157-186.

Burtman, V. S. (2000), Cenozoic crustal shortening between the Pamir and Tien Shan and a reconstruction of the Pamir-Tien Shan transition zone for the Cretaceous and Palaeogene, Tectonophysics, 319, 69-92, doi:10.1016/S0040-1951(00)00022-6.

Burtman, V. S., and P. Molnar (1993), Geological and geophysical evidence for deep subduction of continental crust beneath the Pamir, Spec. Pap. Geol. Soc. Am., 281, 76 pp.

Burtman, V. S., S. F. Skobelev, and P. Molnar (1996), Late Cenozoic slip on the Talas-Ferghana fault, the Tien Shan, central Asia, Geol. Soc. Am. Bull., 108, 1004-1021, doi:10.1130/0016-7606(1996)108<1004: LCSOTT $>2.3 . \mathrm{CO} ; 2$.

Cai, F., L. Ding, and Y. Yue (2011), Provenance analysis of upper Cretaceous strata in the Tethys Himalaya, southern Tibet: Implications for timing of India-Asia collision, Earth Planet. Sci. Lett., 305, 195-206, doi:10.1016/j.eps1.2011.02.055

Cai, J.-X., and K.-J. Zhang (2009), A new model for the Indochina and South China collision during the Late Permian to the Middle Triassic, Tectonophysics, 467, 35-43, doi:10.1016/j.tecto.2008.12.003.

Cande, S. C., and D. V. Kent (1995), Revised calibration of the geomagnetic polarity timescale for the Late Cretaceous and Cenozoic, J. Geophys. Res., 100, 6093-6095, doi:10.1029/94JB03098.

Cande, S. C., P. Patriat, and J. Dyment (2010), Motion between the Indian, Antarctic and African plates in the early Cenozoic, Geophys. J. Int., 183, 127-149, doi:10.1111/j.1365-246X.2010.04737.x.

Cao, K., G. C. Wang, C. Liu, and Y.-N. Meng (2009), Thermochronological evidence of the Cenozoic differential uplift processes of the West Kunlun and its adjacent area, Earth Sci., 34, 895-906.

Capitanio, F. A., G. Morra, S. Goes, R. F. Weinberg, and L. Moresi (2010), India-Asia convergence driven by the subduction of the Greater Indian continent, Nat. Geosci., 3, 136-139, doi:10.1038/ngeo725.

Chakraborty, P. P., and P. K. Khan (2009), Cenozoic geodynamic evolution of the Andaman-Sumatra subduction margin: Current understanding, Isl. Arc, 18, 184-200, doi:10.1111/j.1440-1738.2008.00643.x.

Charreau, J., Y. Chen, S. Gilder, L. Barrier, S. Dominguez, R. Augier, S. Sen, J.-P. Avouac, A. Gallaud, F. Graveleau, and Q. Wang (2009), Neogene uplift of the Tian Shan Mountains observed in the magnetic record of the Jingou River section (northwest China), Tectonics, 28 , TC2008, doi:10.1029/2007TC002137.

Charusiri, P., S. Imsamut, Z. Zhuang, T. Ampaiwan, and X. Xu (2006), Paleomagnetism of the earliest Cretaceous to early late Cretaceous sandstones, Khorat Group, Northeast Thailand: Implications for tectonic plate movement of the Indochina block, Gondwana Res., 9, 310-325, doi:10.1016/j.gr.2005.11.006.

Chen, S. F., and C. J. L. Wilson (1996), Emplacement of the Longmen Shan Thrust-Nappe Belt along the eastern margin of the Tibetan Plateau, J. Struct. Geol., 18, 413-430, doi:10.1016/0191-8141(95)00096-V.

Chen, Y., J. P. Cogné, V. Courtillot, P. Tapponnier, and X. Y. Zhu (1993), Cretaceous paleomagnetic results from western Tibet and tectonic implications, J. Geophys. Res., 98, 17,981-17,999, doi:10.1029/93JB01006.

Chi, C. T., and S. L. Dorobek (2004), Cretaceous palaeomagnetism of Indochina and surrounding regions: Cenozoic tectonic implications, Geol. Soc. Spec. Publ., 226, 273-287, doi:10.1144/GSL.SP.2004.226.01.15

Chiu, H.-Y., S.-L. Chung, F.-Y. Wu, D. Liu, Y.-H. Liang, I.-J. Lin, Y. Lizua L. W. Xie, Y. Wang, and M.-F. Chu (2009), Zircon U-Pb and Hf isotopic constraints from eastern Transhimalayan batholiths on the precollisional magmatic and tectonic evolution in southern Tibet, Tectonophysics, 477 3-19, doi:10.1016/j.tecto.2009.02.034.

Chung, S.-L., T.-Y. Lee, C.-H. Lo, P.-L. Wang, C.-Y. Chen, N. T. Yem, T. T. Hoa, and W. Genyao (1997), Intraplate extension prior to continental extrusion along the Ailao Shan-Red River shear zone, Geology, 25, 311-314, doi:10.1130/0091-7613(1997)025<0311:IEPTCE >2.3.CO;2.

Clark, M. K., and R. Bilham (2008), Miocene rise of the Shillong Plateau and the beginning of the end for the Eastern Himalaya, Earth Planet. Sci. Lett., 269, 337-351, doi:10.1016/j.epsl.2008.01.045

Clark, M. K., and L. H. Royden (2000), Topographic ooze: Building the eastern margin of Tibet by lower crustal flow, Geology, 28, 703-706, doi:10.1130/0091-7613(2000)28<703:TOBTEM>2.0.CO;2. 
Clark, M. K., K. A. Farley, D. Zheng, Z. Wang, and A. R. Duvall (2010), Early Cenozoic faulting of the northern Tibetan Plateau margin from apatite (U-Th)/He ages, Earth Planet. Sci. Lett., 296, 78-88, doi:10.1016/j. epsl.2010.04.051.

Cobbold, P. R., P. Davy, D. Gapais, E. A. Rossello, E. Sadybakasov, J. C. Thomas, J. J. Tondji Biyo, and M. de Urreiztieta (1993), Sedimentary basins and crustal thickening, Tectonophysics, 86, 77-89, doi:10.1016/ 0037-0738(93)90134-Q.

Cocks, L. R. M., and T. H. Torsvik (2007), Siberia, the wandering northern terrane, and its changing geography through the Palaeozoic, Earth Sci. Rev., 82, 29-74, doi:10.1016/j.earscirev.2007.02.001

Cogné, J., N. Halim, Y. Chen, and V. Courtillot (1999), Resolving the problem of shallow magnetizations of Tertiary age in Asia: Insights from paleomagnetic data from the Qiangtang, Kunlun, and Qaidam blocks (Tibet, China), and a new hypothesis, J. Geophys. Res., 104, 17,715-17,734, doi:10.1029/1999JB900153.

Cogné, J.-P., V. A. Kravchinsky, N. Halim, and F. Hankard (2005), Late Jurassic-Early Cretaceous closure of the Mongol Okhotsk Ocean demonstrated by new Mesozoic palaeomagnetic results from the Trans-Baika area (SE Siberia), Geophys. J. Int., 163, 813-832, doi:10.1111/j.1365246X.2005.02782.x.

Coleman, M., and K. V. Hodges (1995), Evidence for Tibetan Plateau uplift before $14 \mathrm{Myr}$ ago from a new minimum age for east-west extension, Nature, 374, 49-52, doi:10.1038/374049a0.

Copley, A., J.-P. Avouac, and J.-Y. Royer (2010), India-Asia collision and the Cenozoic slowdown of the Indian plate: Implications for the forces driving plate motions, J. Geophys. Res., 115, B03410, doi:10.1029/ 2009JB006634.

Coutand, I., M. R. Strecker, J. R. Arrowsmith, G. Hilley, R. C. Thiede, A. Korjenkov, and M. Omuraliev (2002), Late Cenozoic tectonic development of the intramontane Alai Valley, (Pamir-Tien Shan region, central Asia): An example of intracontinental deformation due to the Indo-Eurasia collision, Tectonics, 21(6), 1053, doi:10.1029/2002TC001358.

Coward, M. P., W. S. F. Kidd, Y. Pan, R. M. Shackleton, and Z. Hu (1988), The structure of the 1985 Tibet Geotraverse, Lhasa to Golmud, Philos Trans. R. Soc. London, Ser. A, 327, 307-333, doi:10.1098/rsta.1988.0131.

Cowgill, E. S. (2001), Tectonic evolution of the Altyn Tagh-Western Kunlun Fault System, Northwestern China, Ph.D. thesis, 311 pp., Univ. of Calif., Los Angeles.

Cowgill, E. (2010), Cenozoic right-slip faulting along the eastern margin of the Pamir salient, northwestern China, Geol. Soc. Am. Bull., 122 145-161, doi:10.1130/B26520.1.

Cowgill, E., A. Yin, T. M. Harrison, and X.-F. Wang (2003), Reconstruction of the Altyn Tagh fault based on $\mathrm{U}-\mathrm{Pb}$ geochronology: Role of back thrusts, mantle sutures, and heterogeneous crustal strength in forming the Tibetan Plateau, J. Geophys. Res., 108(B7), 2346, doi:10.1029/ 2002JB002080.

Cox, A., and R. B. Hart (1986), Plate Tectonics: How It Works, Blackwell Sci., Palo Alto, Calif.

Cunningham, W. D. (2005), Active intracontinental transpressional mountain building in the Mongolian Altai: Defining a new class of orogen, Earth Planet. Sci. Lett., 240(2), 436-444, doi:10.1016/j.eps1.2005.09. 013

Cunningham, W. D. (2010), Tectonic setting and structural evolution of the late Cenozoic Gobi Altai Orogen, Geol. Soc. Spec. Publ., 338, 361-387, doi:10.1144/SP338.17.

Cunningham, W. D., B. F. Windley, D. Dornjnamjaa, D. Badamgarav, and M. Saander (1996), Late Cenozoic transpression in southwestern Mongolia and the Gobi-Altai-Tien Shan connection, Earth Planet. Sci. Lett. 140, 67-81, doi:10.1016/0012-821X(96)00048-9.

Curray, J. R., D. G. Moore, L. A. Lawver, F. J. Emmel, E. W. Raitt, M Henry, and R. Kielheffer (1979), Tectonics of the Andaman Sea and Burma, in Geological and Geophysical Investigations of Continental Margins, edited by J. Watkins et al., AAPG Mem., 29, 189-198.

Curray, J. R., F. J. Emmel, D. G. Moore, and E. W. Raitt (1982), Structure, tectonics and geological history of the Northeastern Indian Ocean, in The Ocean Basins and Margins, vol. 6, The Indian Ocean, edited by A. E. M. Nairn and F. G. Stehli, pp. 399-450, Plenum, New York.

Darby, B. J., and B. D. Ritts (2007), Mesozoic structural architecture of the Lang Shan, north-central China: Intraplate contraction, extension, and synorogenic sedimentation, J. Struct. Geol., 29, 2006-2016, doi:10.1016/j.jsg.2007.06.011

Darby, B. J., B. D. Ritts, Y. Yue, and Q. Meng (2005), Did the Altyn Tagh fault extend beyond the Tibetan Plateau?, Earth Planet. Sci. Lett., 240, 425-435, doi:10.1016/j.epsl.2005.09.011.

Davis, G. A., B. J. Darby, Z. Yadong, and T. L. Spell (2002), Geometric and temporal evolution of an extensional detachment fault, Hohho metamorphic core complex, Inner Mongolia, China, Geology, 30(11),
1003-1006, doi:10.1130/0091-7613(2002)030<1003:GATEOA >2.0. $\mathrm{CO} ; 2$

DeCelles, P. G., D. M. Robinson, and G. Zandt (2002), Implications of shortening in the Himalayan fold-thrust belt for uplift of the Tibetan Plateau, Tectonics, 21(6), 1062, doi:10.1029/2001TC001322.

DeCelles, P. G., P. Kapp, L. Ding, and G. E. Gehrels (2007), Late Cretaceous to middle Tertiary basin evolution in the central Tibetan Plateau: Changing environments in response to tectonic partitioning, aridification, and regional elevation gain, Geol. Soc. Am. Bull., 119, 654-680, doi:10.1130/B26074.1.

Dewey, J. F., R. M. Shackleton, C. Chang, and Y. Sun (1988), The tectonic evolution of the Tibetan Plateau, Philos. Trans. R. Soc. London, Ser. A 327, 379-413, doi:10.1098/rsta.1988.0135.

Diament, M., H. Harjono, K. Karta, C. Deplus, D. Dahrin, M. T. J. Zen, and J. A. Malod (1992), Mentawai fault zone off Sumatra: A new key to the geodynamics of western Indonesia, Geology, 20, 259-262, doi:10.1130/ 0091-7613(1992)020<0259:MFZOSA > 2.3.CO;2

Ding, G., J. Chen, Q. Tian, X. Shen, C. Xing, and K. Wei (2004), Active faults and magnitudes of left-lateral displacement along the northern margin of the Tibetan Plateau, Tectonophysics, 380, 243-260, doi:10.1016/j. tecto.2003.09.022.

Ding, L., and Q. Lai (2003), New geological evidence of crustal thickening in the Gangdese block prior to the Indo-Asian collision, Chin. Sci. Bull., $48,1604-1610$.

Ding, L., P. Kapp, and X. Wan (2005), Paleocene-Eocene record of ophiolite obduction and initial India-Asia collision, south central Tibet, Tectonics, 24, TC3001, doi:10.1029/2004TC001729.

Ding, L., P. Kapp, Y. Yue, and Q. Lai (2007), Postcollisional calc-alkaline lavas and xenoliths from the southern Qiangtang terrane, central Tibet, Earth Planet. Sci. Lett., 254, 28-38, doi:10.1016/j.epsl.2006.11.019.

Dupont-Nivet, G., R. F. Butler, A. Yin, and X. Chen (2002), Paleomagnetism indicates no Neogene rotation of the Qaidam Basin in northern Tibet during Indo-Asian collision, Geology, 30(3), 263-266, doi:10.1130/ 0091-7613(2002)030<0263:PINNRO >2.0.CO;2.

Dupont-Nivet, G., B. K. Horton, R. F. Butler, J. Wang, J. Zhou, and G. L. Waanders (2004a), Paleogene clockwise tectonic rotation of the XiningLanzhou region, northeastern Tibetan Plateau, J. Geophys. Res., 109, B04401, doi:10.1029/2003JB002620.

Dupont-Nivet, G., D. Robinson, R. F. Butler, A. Yin, and H. J. Melosh (2004b), Concentration of crustal displacement along a weak Altyn Tagh fault: Evidence from paleomagnetism of the northern Tibetan Plateau, Tectonics, 23, TC1020, doi:10.1029/2002TC001397.

Dupont-Nivet, G., P. Lippert, D. J. J. van Hinsbergen, M. J. M. Meijers, and P. Kapp (2010a), Paleolatitude and age of the Indo-Asia collision: Paleomagnetic constraints, Geophys. J. Int., 182, 1189-1198, doi:10.1111/j.1365-246X.2010.04697.x.

Dupont-Nivet, G., D. J. J. van Hinsbergen, and T. H. Torsvik (2010b), Persistently low Asian paleolatitudes: Implications for the India-Asia collision history, Tectonics, 29, TC5016, doi:10.1029/2008TC002437.

Duvall, A. R., and M. K. Clark (2010), Dissipation of fast strike-slip faulting within and beyond northeastern Tibet, Geology, 38, 223-226, doi:10.1130/G30711.1.

Duvall, A. R., M. K. Clark, B. A. van der Pluijm, and C. Li (2011), Direct dating of Eocene reverse faulting in northeastern Tibet using Ar-dating of fault clays and low-temperature thermochronometry, Earth Planet. Sci. Lett., 304, 520-526, doi:10.1016/j.eps1.2011.02.028.

England, P. C., and G. A. Houseman (1986), Finite strain calculations of continental deformation: 2. Comparison with the India-Asia collision, J. Geophys. Res., 91, 3664-3676, doi:10.1029/JB091iB03p03664.

England, P. C., and P. Molnar (1990), Right-lateral shear and rotation as the explanation for strike-slip faulting in eastern Tibet, Nature, 344 140-142, doi:10.1038/344140a0.

England, P. C., and P. Molnar (1997), The field on crustal velocity in Asia calculated from Quaternary rates of slip on faults, Geophys. J. Int., 130, 551-582, doi:10.1111/j.1365-246X.1997.tb01853.x.

Enkelmann, E., L. Ratschbacher, R. C. Jonckheere, R. Nestler, M. Fleischer, R. Gloaguen, B. R. Hacker, Y. Q. Zhang, and Y.-S. Ma (2006), Cenozoic exhumation and deformation of northeastern Tibet and the Qinling: Is Tibetan lower crustal flow diverging around the Sichuan Basin?, Geol. Soc. Am. Bull., 118, 651-671, doi:10.1130/ B25805.1.

Enkin, R. J., Z. Yang, Y. Chen, and V. Courtillot (1992), Paleomagnetic constraints on the geodynamic history of the major blocks of China from the Permian to the present, J. Geophys. Res., 97, 13,953-13,989, doi:10.1029/92JB00648.

Ferrari, O. M., C. Hochard, and G. M. Stampfli (2008), An alternative plate tectonic model for the Palaeozoic-Early Mesozoic Palaeotethyan evolution of Southeast Asia (northern Thailand-Burma), Tectonophysics, 451, 346-365, doi:10.1016/j.tecto.2007.11.065 
Fu, B., and Y. Awata (2007), Displacement and timing of left-lateral faulting in the Kunlun Fault Zone, northern Tibet, inferred from geologic and geomorphic features, J. Asian Earth Sci., 29, 253-265, doi:10.1016/j. jseaes.2006.03.004

Fu, B., Y. Awata, J. Du, and W. He (2005), Late Quaternary systematic stream offsets caused by repeated large seismic events along the Kunlun Fault, northern Tibet, Geomorphology, 71, 278-292, doi:10.1016/j. geomorph.2005.03.001.

Fuller, M., J. R. Ali, S. J. Moss, G. M. Frost, B. Richter, and A. Mahfi (1999), Paleomagnetism of Borneo, J. Asian Earth Sci., 17, 3-24, doi:10.1016/S0743-9547(98)00057-9.

Fyhn, M. B. W., L. O. Boldreel, and L. H. Nielsen (2009), Geological development of the Central and South Vietnamese margin: Implications for the establishment of the South China Sea, Indochinese escape tectonics and Cenozoic volcanism, Tectonophysics, 478, 184-214, doi:10.1016/j. tecto.2009.08.002.

Fyhn, M. B. W., L. O. Boldreel, and L. H. Nielsen (2010a), Escape tectonism in the Gulf of Thailand: Paleogene left-lateral pull-apart rifting in the Vietnamese part of the Malay Basin, Tectonophysics, 483, 365-376, doi:10.1016/j.tecto.2009.11.004.

Fyhn, M. B. W., S. A. S. Pedersen, L. O. Boldreel, L. H. Nielsen, P. F. Green, P. T. Dien, L. T. Huyen, and D. Frei (2010b), Palaeocene-early Eocene inversion of the Phuquoc-Kampot Som Basin: SE Asian deformation associated with the suturing of Luconia, J. Geol. Soc., 167, 281-295, doi:10.1144/0016-76492009-039.

Gaina, C., W. R. Roest, and R. D. Muller (2002), Late CretaceousCenozoic deformation of northeast Asia, Earth Planet. Sci. Lett. 197, 273-286, doi:10.1016/S0012-821X(02)00499-5.

Gansser, A. (1964), The Geology of the Himalayas, 289 pp., Wiley Interscience, New York.

Gansser, A. (1980), The significance of the Himalayan suture zone, Tectonophysics, 62, 37-52, doi:10.1016/0040-1951(80)90134-1.

Garzione, C. N., P. G. DeCelles, T. P. Ohja, and B. N. Upreti (2003), Eastwest extension and Miocene environmental change in the southern Tibetan Plateau: Thakkhola graben, central Nepal, Geol. Soc. Am. Bull., 115, 3-20, doi:10.1130/0016-7606(2003)115<0003:EWEAME >2.0. $\mathrm{CO} ; 2$.

Gehrels, G. E., A. Yin, and X.-F. Wang (2003), Detrital zircon geochronology of the northwestern Tibetan Plateau, Geol. Soc. Am. Bull., 115, 881-896, doi:10.1130/0016-7606(2003)115<0881:DGOTNT $>2.0$.CO;2.

Gill, J. B. (1981), Orogenic Andesites and Plate Tectonics, 390 pp. Springer, New York.

Gnos, E., A. Immenhauser, and T. Peters (1997), Late Cretaceous/early Tertiary convergence between the Indian and Arabian plates recorded in ophiolites and related sediments, Tectonophysics, 271, 1-19, doi:10.1016/S0040-1951(96)00249-1.

Godard, V., R. Pik, J. Lave, R. Cattin, B. Tibari, J. De Sigoyer, M. Pubellier, and J. Zhu (2009), Late Cenozoic evolution of the central Longmen Shan, eastern Tibet: Insight from (U-Th)/He thermochronometry, Tectonics, 28, TC5009, doi:10.1029/2008TC002407.

Graham, S. A., M. S. Hendrix, L. B. Wang, and A. R. Carroll (1993), Collisional successor basins of western China: Impact of tectonic inheritance on sand composition, Geol. Soc. Am. Bull., 105, 323-344, doi:10.1130/ 0016-7606(1993)105<0323:CSBOWC $>2.3 . \mathrm{CO} ; 2$.

Graham, S. A., M. S. Hendrix, C. L. Johnson, D. Badamgarav, G. Badarch, J. Amory, M. Porter, R. Barsbold, L. E. Webb, and B. R. Hacker (2001), Sedimentary record and tectonic implications of Mesozoic rifting in southeast Mongolia, Geol. Soc. Am. Bull., 113(12), 1560-1579, doi:10.1130/0016-7606(2001)113<1560:SRATIO >2.0.CO;2.

Green, O. R., M. P. Searle, R. I. Corfield, and R. M. Corfield (2008), Cretaceous-Tertiary carbonate platform evolution and the age of the India-Asia collision along the Ladakh Himalaya (northwest India), $J$. Geol., 116, 331-353, doi:10.1086/588831.

Guillot, S., E. Garzanti, D. Baratoux, D. Marquer, G. Mahéo, and J. de Sigoyer (2003), Reconstructing the total shortening history of the NW Himalaya, Geochem. Geophys. Geosyst., 4(7), 1064, doi:10.1029/ 2002GC000484.

Gutscher, M.-A., W. Spakman, H. Bijwaard, and E. R. Engdahl (2000), Geodynamics of flat subduction: Seismicity and tomographic constraints from the Andean margin, Tectonics, 19, 814-833, doi:10.1029/ 1999TC001152.

Guynn, J. H., P. Kapp, A. Pullen, M. T. Heizler, G. E. Gehrels, and L. Ding (2006), Tibetan basement rocks near Amdo reveal "missing" Mesozoic tectonism along the Bangong suture, central Tibet, Geology, 34, 505-508, doi:10.1130/G22453.1.

Hacker, B. R., P. Luffi, V. Lutkov, V. Minaev, L. Ratschbacher, T. Plank, M. N. Ducea, A. Patino-Douce, M. McWilliams, and J. Metcalf (2005), Near-ultrahigh pressure processing of continental crust: Miocene crustal xenoliths from the Pamir, J. Petrol., 46, 1661-1687, doi:10.1093/ petrology/egi030.

Hacker, B. R., S. R. Wallis, L. Ratschbacher, M. Grove, and G. E. Gehrels (2006), High-temperature geochronology constraints on the tectonic history and architecture of the ultrahigh-pressure Dabie-Sulu Orogen, Tectonics, 25, TC5006, doi:10.1029/2005TC001937.

Hafkenscheid, E., M. J. R. Wortel, and W. Spakman (2006), Subduction history of the Tethyan region derived from seismic tomography and tectonic reconstructions, J. Geophys. Res., 111, B08401, doi:10.1029/ 2005JB003791.

Hall, R. (2002), Cenozoic geological and plate tectonic evolution of SE Asia and the SW Pacific: Computer-based reconstructions, model and animations, J. Asian Earth Sci., 20, 353-431, doi:10.1016/S1367-9120 (01)00069-4.

Hall, R., M. W. A. van Hattum, and W. Spakman (2008), Impact of IndiaAsia collision on SE Asia: The record in Borneo, Tectonophysics, 451, 366-389, doi:10.1016/j.tecto.2007.11.058.

Hamburger, M. W., D. R. Sarewitz, T. L. Pavlis, and G. A. Popandopulo (1992), Structural and seismic evidence for intracontinental subduction in the Peter the First Range, Central Asia, Geol. Soc. Am. Bull., 104, 397-408, doi:10.1130/0016-7606(1992)104<0397:SASEFI $>2.3$ CO 2.

Hankard, F., J. P. Cogné, X. Quidelleur, A. Bayasgalan, and P. Lkhagvadorj (2007), Paleomagnetism and K-Ar dating of Cretaceous basalts from Mongolia, Geophys. J. Int., 169, 898-908, doi:10.1111/j.1365246X.2007.03292.x.

Harris, N. B. W., R. H. Xu, C. L. Lewis, C. J. Hawkesworth, and Y. Q. Zhang (1988), Isotope geochemistry of the 1985 Tibet Geotraverse, Lhasa to Golmud, Philos. Trans. R. Soc. London, 327, 263-285, doi:10.1098/rsta.1988.0129.

Harrison, T. M., P. Copeland, W. S. F. Kidd, and A. Yin (1992), Raising Tibet, Science, 255, 1663-1670, doi:10.1126/science.255.5052.1663.

Harrison, T. M., P. Copeland, W. S. F. Kidd, and O. M. Lovera (1995), Activation of the Nyainqentanghla shear zone: Implications for uplift of the southern Tibetan Plateau, Tectonics, 14, 658-676, doi:10.1029/ 95TC00608.

Harrison, T. M., P. H. Leloup, F. J. Ryerson, P. Tapponnier, R. Lacassin, and C. Wenji (1996), Diachronous initiation of transtension along the Ailao Shan-Red River shear zone, in The Tectonic Evolution of Asia, edited by A. Yin and T. M. Harrison, pp. 208-225, Cambridge Univ. Press, Cambridge, U. K

He, J., and J. Chery (2008), Slip rates of the Altyn Tagh, Kunlun and Karakorum faults (Tibet) from 3D mechanical modeling, Earth Planet. Sci. Lett., 274, 50-58, doi:10.1016/j.eps1.2008.06.049.

He, S., P. Kapp, P. G. DeCelles, G. E. Gehrels, and M. T. Heizler (2007), Cretaceous-Tertiary geology of the Gangdese Arc in the Linzhou area, southern Tibet, Tectonophysics, 433, 15-37, doi:10.1016/j. tecto.2007.01.005

Heermance, R. V., J. Chen, D. W. Burbank, and C. Wang (2007), Chronology and tectonic controls of Late Tertiary deposition in the southwestern Tian Shan foreland, NW China, Basin Res., 19, 599-632, doi:10.1111/ j.1365-2117.2007.00339.x.

Hendrix, M. S., T. A. Dumitru, and S. A. Graham (1994), Late Oligoceneearly Miocene unroofing in the Chinese Tian Shan: An early effect of the India-Asia collision, Geology, 22, 487-490, doi:10.1130/0091-7613 (1994) $022<0487:$ LOEMUI $>2.3$. CO; 2 .

Hodges, K. V. (2000), Tectonics of the Himalaya and southern Tibet from two perspectives, Geol. Soc. Am. Bull., 112, 324-350, doi:10.1130/00167606(2000)112<324:TOTHAS $>2.0$.CO; 2 .

Horton, B. K., A. Yin, M. S. Spurlin, J. Zhou, and J. Wang (2002), Paleocene-Eocene syncontractional sedimentation in narrow, lacustrine-dominated basins of east-central Tibet, Geol. Soc. Am. Bull., 114, 771-786, doi:10.1130/0016-7606(2002)114<0771:PESSIN>2.0.CO;2.

Howard, J. P., W. D. Cunningham, S. J. Davies, A. H. Dijkstra, and G. Badarch (2003), The stratigraphic and structural evolution of the Dzereg Basin, western Mongolia: Clastic sedimentation, transpressional faulting and basin destruction in an intraplate, intracontinental setting, Basin Res., 15, 45-72, doi:10.1046/j.1365-2117.2003.00198.x.

Hsü, K. J., G.-T. Pan, and A. M. C. Șengör (1995), Tectonic evolution of the Tibetan Plateau: A working hypothesis based on the archipelago model of orogenesis, Int. Geol. Rev., 37, 473-508, doi:10.1080/ 00206819509465414

Huang, K., and N. D. Opdyke (1992), Paleomagnetism of Cretaceous to lower Tertiary rocks from southwestern Sichuan: A revisit, Earth Planet. Sci. Lett., 112, 29-40, doi:10.1016/0012-821X(92)90004-F.

Huang, K., and N. D. Opdyke (1993), Paleomagnetic results from Cretaceous and Jurassic rocks of South and Southwest Yunnan: Evidence for large clockwise rotations in the Indochina and Shan-Thai-Malay terranes, Earth Planet. Sci. Lett., 117, 507-524, doi:10.1016/0012$821 \mathrm{X}(93) 90100-\mathrm{N}$. 
Huang, K., N. D. Opdyke, J. Li, and X. Peng (1992), Paleomagnetism of Cretaceous rocks from eastern Qiangtang terrane of Tibet, J. Geophys. Res., 97, 1789-1799, doi:10.1029/91JB02747.

Hubbard, J., and J. H. Shaw (2009), Uplift of the Longmen Shan and Tibetan Plateau, and the 2008 Wenchuan $(\mathrm{M}=7.9)$ earthquake, Nature, 458, 194-197, doi:10.1038/nature07837.

Jarrard, R. D. (1986), Terrane motion by strike-slip faulting of forearc slivers, Geology, 14, 780-783, doi:10.1130/0091-7613(1986)14<780 TMBSFO $>2.0 . \mathrm{CO} ; 2$.

Jessup, M. J., and J. M. Cottle (2010), Progression from south-directed extrusion to orogen-parallel extension in the southern margin of the Tibetan Plateau, Mount Everest region, Tibet, J. Geol., 118, 467-486, doi:10.1086/655011

Johnson, M. R. W. (2002), Shortening budgets and the role of continental subduction during the India-Asia collision, Earth Sci. Rev., 59, 101-123, doi:10.1016/S0012-8252(02)00071-5.

Johnson, S. Y., and N. Alam (1991), Sedimentation and tectonics of the Sylhet Trough, Bangladesh, Geol. Soc. Am. Bull., 103, 1513-1527, doi:10.1130/0016-7606(1991) $103<1513$ :SATOTS $>2.3 . C O ; 2$

Jolivet, M., M. Brunel, D. Seward, Z. Xu, J. Yang, F. Roger, P. Tapponnier, J. Malavieille, N. Arnaud, and C. Wu (2001), Mesozoic and Cenozoic tectonics of the northern edge of the Tibetan Plateau: Fission-track constraints, Tectonophysics, 343, 111-134, doi:10.1016/S0040-1951(01) 00196-2.

Jolivet, M., et al. (2007), Mongolian summits: An uplifted, flat, but still preserved erosion surface, Geology, 35(10), 871-874, doi:10.1130/ G23758A.1.

Jolivet, M., T. De Boisgrollier, C. Petit, M. Fournier, V. A. Sankov, J.-C. Ringenbach, L. Byzov, A. I. Miroshnichenko, S. N. Kovalenko, and S. V. Anisimova (2009), How old is the Baikal Rift Zone? Insigh from apatite fission track thermochronology, Tectonics, 28, TC3008, doi:10.1029/2008TC002404.

Jolivet, M., S. Dominguez, J. Charreau, Y. Chen, Y. Li, and Q. Wang (2010), Mesozoic and Cenozoic tectonic history of the central Chinese Tian Shan: Reactivated tectonic structures and active deformation, Tectonics, 29, TC6019, doi:10.1029/2010TC002712.

Kamesh Raju, K. A., R. Ramprasad, P. S. Rao, B. R. Rao, and J. Varghese (2004), New insights into the tectonic evolution of the Andaman basin, northeast Indian Ocean, Earth Planet. Sci. Lett., 221, 145-162, doi:10.1016/S0012-821X(04)00075-5.

Kapp, J. L. D., T. M. Harrison, P. Kapp, M. Grove, O. M. Lovera, and L. Ding (2005), Nyainqentanglha Shan: A window into the tectonic, thermal, and geochemical evolution of the Lhasa block, southern Tibet, J. Geophys. Res., 110, B08413, doi:10.1029/2004JB003330.

Kapp, P., A. Yin, C. E. Manning, M. A. Murphy, T. M. Harrison, M. Spurlin D. Lin, X.-G. Deng, and C.-M. Wu (2000), Blueschist-bearing metamorphic core complexes in the Qiangtang block reveal deep crustal structure of northern Tibet, Geology, 28, 19-22, doi:10.1130/0091-7613(2000)28<19: BMCCIT>2.0.CO;

Kapp, P., M. A. Murphy, A. Yin, T. M. Harrison, L. Ding, and J. Guo (2003), Mesozoic and Cenozoic tectonic evolution of the Shiquanhe area of western Tibet, Tectonics, 22(4), 1029, doi:10.1029/2001TC001332.

Kapp, P., A. Yin, T. M. Harrison, and L. Ding (2005), Cretaceous-Tertiary shortening, basin development and volcanism in central Tibet, Geol. Soc. Am. Bull., 117, 865-878, doi:10.1130/B25595.1.

Kapp, P., P. G. DeCelles, G. E. Gehrels, M. Heizler, and L. Ding (2007a), Geological records of the Cretaceous Lhasa-Qiangtang and Indo-Asian collisions in the Nima basin area, central Tibet, Geol. Soc. Am. Bull., 119, 917-933, doi:10.1130/B26033.1.

Kapp, P., P. G. DeCelles, A. L. Leier, J. M. Fabijanic, S. He, A. Pullen, G. E. Gehrels, and L. Ding (2007b), The Gangdese retroarc thrust belt revealed, GSA Today, 17, 4-9, doi:10.1130/GSAT01707A.1.

Khan, P. K, and P. P. Chakraborty (2005), Two-phase opening of Andaman Sea: A new seismotectonic insight, Earth Planet. Sci. Lett., 229, 259-271, doi:10.1016/j.epsl.2004.11.010.

King, R. F. (1955), The remanent magnetism of artificially deposited sediments, Mon. Not. R. Astron. Soc., 7, 115-134.

Kirby, E., K. X. Whipple, K. V. Hodges, P. W. Reiners, M. A. Krol, K. A. Farley, W.-Q. Tan, and Z.-L. Chen (2002), Late Cenozoic evolution of the eastern margin of the Tibetan Plateau: Inferences from ${ }^{40} \mathrm{Ar} /{ }^{39} \mathrm{Ar}$ and (U-Th)/He thermochronology, Tectonics, 21(1), 1001, doi:10.1029/ $2000 \mathrm{TC} 001246$

Kirby, E., N. Harkins, E. Wang, X. Shi, C. Fan, and D. W. Burbank (2007), Slip rate gradients along the eastern Kunlun fault, Tectonics, 26, TC2010, doi:10.1029/2006TC002033.

Klootwijk, C. T., P. J. Conaghan, and C. M. Powell (1985), The Himalayan Arc: Large-scale continental subduction, oroclinal bending and back-arc spreading, Earth Planet. Sci. Lett., 75, 167-183, doi:10.1016/0012-821X (85)90099-8.
Klootwijk, C. T., R. Nazirullah, and K. A. De Jong (1986), Palaeomagnetic constraints on formation of the Mianwali reentrant, Trans-Indus and western Salt Range, Pakistan, Earth Planet. Sci. Lett., 80, 394-414, doi:10.1016/0012-821X(86)90120-2.

Klootwijk, C. T., P. J. Conaghan, R. Nazirullah, and K. A. De Jong (1994), Further palaeomagnetic data from Chitral (eastern Hindukush): Evidence for an early India-Asia contact, Tectonophysics, 237, 1-25, doi:10.1016/ 0040-1951(94)90156-2.

Korjenkov, A. M., A. V. Bobrovskii, and E. M. Mamyrov (2010), Evidence for strong paleoearthquakes along the Talas-Fergana Fault near the Kök-Bel Pass, Kyrgyzstan, Geotectonics, Engl. Transl., 44, 262-270, doi:10.1134/S0016852110030040.

Kosarev, G. L., N. V. Petersen, L. P. Vinnik, and S. W. Roecker (1993), Receiver functions for the Tien Shan analog broadband network: Contrasts in the evolution of structures across the Talasso-Fergana Fault, J. Geophys. Res., 98, 4437-4448, doi:10.1029/92JB02651.

Lacassin, R., P. H. Leloup, and P. Tapponnier (1993), Bounds on strain in large Tertiary shear zone of SE Asia from boudinage restoration, J. Struct. Geol., 15, 677-692, doi:10.1016/0191-8141(93)90055-F.

Lacassin, R., et al. (2004), Large-scale geometry, offset and kinematic evolution of the Karakorum fault, Tibet, Earth Planet. Sci. Lett., 219 , 255-269, doi:10.1016/S0012-821X(04)00006-8

Lee, H.-Y., S.-L. Chung, C.-H. Lo, J. Ji, T.-Y. Lee, Q. Qian, and Q. Zhang (2009), Eocene Neotethyan slab breakoff in southern Tibet inferred from the Linzizong volcanic record, Tectonophysics, 477, 20-35, doi:10.1016/ j.tecto.2009.02.031

Lee, T.-Y., and L. A. Lawver (1995), Cenozoic plate reconstruction of Southeast Asia, Tectonophysics, 251, 85-138, doi:10.1016/0040-1951 (95)00023-2.

Leeder, M. R., A. B. Smith, and J. Yin (1988), Sedimentology, palaeoecology and palaeoenvironmental evolution of the 1985 Lhasa to Golmud Geotraverse, Philos. Trans. R. Soc. London, Ser. A, 327 107-143, doi:10.1098/rsta.1988.0123.

Leier, A. L., P. G. DeCelles, P. Kapp, and L. Ding (2007), The Takena Formation of the Lhasa terrane, southern Tibet: The record of a Late Cretaceous retroarc foreland basin, Geol. Soc. Am. Bull., 119, 31-48, doi:10.1130/B25974.1.

Leith, W., and W. Alvarez (1985), Structure of the Vakhsh fold-and -thrust belt, Tadjik SSR: Geological mapping on a Landsat image base, Geol. Soc. Am. Bull., 96, 875-885, doi:10.1130/0016-7606(1985)96<875: SOTVFB $>2.0 . \mathrm{CO} ; 2$

Leloup, P. H., R. Lacassin, P. Tapponnier, U. Schärer, Z. Dalai, X. Liu, L. Zhang, S. Ji, and T. T. Phan Trong (1995), The Ailao Shan-Red River shear zone (Yunnan, China), Tertiary transform boundary of Indochina, Tectonophysics, 251, 3-84, doi:10.1016/0040-1951(95)00070-4.

Leloup, P. H., N. Arnaud, R. Lacassin, J. R. Kienast, T. M. Harrison, T. T. Phan Trong, A. Replumaz, and P. Tapponnier (2001), New constraints on the structure, thermochronology, and timing of the Ailao Shan-Red River shear zone, SE Asia, J. Geophys. Res., 106, 6683-6732, doi:10.1029/ 2000JB900322.

Leloup, P. H., G. Mahéo, N. Arnaud, E. Kali, E. Boutonnet, D. Liu, X. Liu, and H. Li (2010), The South Tibet detachment shear zone in the Dinggye area: Time constraints on extrusion models of the Himalayas, Earth Planet. Sci. Lett., 292, 1-16, doi:10.1016/j.eps1.2009.12.035.

Leloup, P. H., E. Boutonnet, W. J. Davis, and K. Hattori (2011), Longlasting intracontinental strike-slip faulting: New evidence from the Karakorum shear zone in the Himalayas, Terra Nova, 23, 92-99.

Li, A., and C. Chen (2006), Shear wave splitting beneath the central Tien Shan and tectonic implications, Geophys. Res. Lett., 33, L22303, doi:10.1029/2006GL027717.

Li, C., R. D. Van der Hilst, A. Meltzer, and E. R. Engdahl (2008), Subduction of the Indian lithosphere beneath the Tibetan Plateau and Burma Earth Planet. Sci. Lett., 274, 157-168, doi:10.1016/j.eps1.2008.07.016.

Li, C.-X., G. Dupont-Nivet, and Z.-J. Guo (2011), Magnetostratigraphy of the Northern Tian Shan foreland, Taxi He section, China, Basin Res., 23 , 101-117, doi:10.1111/j.1365-2117.2010.00475.x.

Li, Y., P. A. Allen, A. L. Densmore, and X. Qiang (2003), Evolution of the Longmen Shan Foreland Basin (western Sichuan, China) during the Late Triassic Indosinian Orogeny, Basin Res., 15, 117-138, doi:10.1046/ j.1365-2117.2003.00197.x.

Liebke, U., E. Appel, U. Neumann, B. Antolin, L. Ding, and X. Qiang (2010), Position of the Lhasa terrane prior to India-Asia collision derived from palaeomagnetic inclinations of $53 \mathrm{Ma}$ old dykes of the Linzhou Basin: Constraints on the age of collision and post-collisional shortening within the Tibetan Plateau, Geophys. J. Int., 182, 1199-1215, doi:10.1111/j.1365-246X.2010.04698.x.

Lippert, P. C. (2010), Rock magnetic and paleomagnetic applications to Paleogene climate change and tectonics: Studies from eastern North America and central Tibet, thesis, Univ. of Calif., Santa Cruz. 
Lippert, P. C., X. Zhao, R. S. Coe, and C.-H. Lo (2011), Palaeomagnetism and ${ }^{40} \mathrm{Ar} /{ }^{39} \mathrm{Ar}$ geochronology of upper Palaeogene volcanic rocks from Central Tibet: Implications for the Central Asia inclination anomaly, the palaeolatitude of Tibet and post-50 Ma shortening within Asia, Geophys. J. Int., 184, 131-161, doi:10.1111/j.1365-246X.2010.04833.x.

Liu, Y., and H. Morinaga (1999), Cretaceous palaeomagnetic results from Hainan Island in south China supporting the extrusion model of Southeast Asia, Tectonophysics, 301, 133-144, doi:10.1016/S0040-1951(98) 00216-9.

Liu, Z., C. Wang, and H. Yi (2001), Evolution and mass accumulation of the Cenozoic Hoh Xil basin, northern Tibet, J. Sediment. Res., 71, 971-984, doi:10.1306/030901710971.

Liu, Z., X. Zhao, C. Wang, S. Liu, and H. Yi (2003), Magnetostratigraphy of Tertiary sediments from the Hoh Xil Basin: Implications for the Cenozoic tectonic history of the Tibetan Plateau, Geophys. J. Int., 154, 233-252, doi:10.1046/j.1365-246X.2003.01986.x.

Long, S. P., N. McQuarrie, T. Tobgay, and D. Grujic (2011), Geometry and crustal shortening of the Himalayan fold-thrust belt, eastern and centra Bhutan, Geol. Soc. Am. Bull., 123, 1427-1447, doi:10.1130/B30203.1.

Lyon-Caen, H., and P. Molnar (1984), Gravity anomalies and the structure of western Tibet and the southern Tarim Basin, Geophys. Res. Lett., 11, 1251-1254, doi:10.1029/GL011i012p01251.

Malod, J. A., and B. M. Kemal (1996), The Sumatra margin: Oblique subduction and lateral displacement of the accretionary prism, Geol. Soc. Spec. Publ., 106, 19-28, doi:10.1144/GSL.SP.1996.106.01.03.

Malod, J. A., K. Karta, M.-O. Beslier, and M. T. J. Zen (1995), From normal to oblique subduction: Tectonic relationships between Java and Sumatra, J. Southeast Asian Earth Sci., 12, 85-93, doi:10.1016/07439547(95)00023-2.

Mattauer, M. (1992), The Songpan-Garze Triassic belt of west Sichuan and eastern Tibet: A decollement fold belt on a passive margin, C. R. Geosci., 314, 619-626.

Matte, P., P. Tapponnier, N. Arnaud, L. Bourjot, J.-P. Avouac, P. Vidal, Q Liu, Y. Pan, and Y. Wang (1996), Tectonics of western Tibet, between the Tarim and the Indus, Earth Planet. Sci. Lett., 142, 311-330, doi:10.1016/0012-821X(96)00086-6.

Mattern, F., W. Schneider, Y. Li, and X. Li (1996), A traverse through the western Kunlun (Xinjiang, China): Tentative geodynamic implications for the Paleozoic and Mesozoic, Geol. Rundsch., 85, 705-722, doi:10.1007/BF02440106.

Maurin, T., and C. Rangin (2009), Structure and kinematics of the IndoBurmese Wedge: Recent and fast growth of the outer wedge, Tectonics, 28, TC2010, doi:10.1029/2008TC002276.

McCaffrey, R. (1992), Oblique plate convergence, slip vectors, and forearc deformation, J. Geophys. Res., 97, 8905-8915, doi:10.1029/92JB00483.

Meng, Q.-R., J.-M. Hu, J.-Q. Jin, and D.-F. Xu (2003), Tectonics of the late Mesozoic wide extensional basin system in the China-Mongolia border region, Basin Res., 15, 397-415, doi:10.1046/j.1365-2117.2003.00209.x.

Merkouriev, S., and C. DeMets (2006), Constraints on Indian plate motion since $20 \mathrm{Ma}$ from dense Russian magnetic data: Implications for Indian plate dynamics, Geochem. Geophys. Geosyst., 7, Q02002, doi:10.1029/ 2005GC001079.

Metcalfe, I. (1996), Pre-Cretaceous evolution of SE Asian terranes, Geol Soc. Spec. Publ., 106, 97-122, doi:10.1144/GSL.SP.1996.106.01.09.

Metelkin, D. V., V. A. Vernikovsky, A. Y. Kazansky, and M. T. D Wingate (2010), Late Mesozoic tectonics of Central Asia based on paleomagnetic evidence, Gondwana Res., 18, 400-419, doi:10.1016/ j.gr.2009.12.008.

Meyer, B., P. Tapponnier, L. Bourjot, F. Métivier, Y. Gaudemer, G. Peltzer, S. Guo, and Z. Chen (1998), Crustal thickening in Gansu-Qinghai, lithospheric mantle subduction, and oblique, strike-slip controlled growth of the Tibet Plateau, Geophys. J. Int., 135, 1-47, doi:10.1046/j.1365246X.1998.00567.x

Mitchell, A. H. G. (1981), Phanerozoic plate boundaries in mainland SE Asia, the Himalayas and Tibet, J. Geol. Soc., 138, 109-122, doi:10.1144/gsjgs.138.2.0109.

Mock, C., N. O. Arnaud, and J.-M. Cantagrel (1999), An early unroofing in northeastern Tibet? Constraints from ${ }^{40} \mathrm{Ar} /{ }^{39} \mathrm{Ar}$ thermochronology on granitoids from the eastern Kunlun range (Qianghai, NW China), Earth Planet. Sci. Lett., 171, 107-122, doi:10.1016/S0012-821X(99)00133-8.

Molnar, P. (1994), Quaternary climate change and the formation of river terraces across growing anticlines on the north flank of the Tien Shan, China, J. Geol., 102, 583-602, doi:10.1086/629700.

Molnar, P., and J. M. Stock (2009), Slowing of India's convergence with Eurasia since $20 \mathrm{Ma}$ and its implications for Tibetan mantle dynamics, Tectonics, 28, TC3001, doi:10.1029/2008TC002271.

Molnar, P., and P. Tapponnier (1975), Cenozoic tectonics of Asia: Effects of a continental collision, Science, 189, 419-426, doi:10.1126/ science.189.4201.419.
Morley, C. K. (2004), Nested strike-slip duplexes, and other evidence for Late Cretaceous-Palaeogene transpressional tectonics before and during India-Eurasia collision, in Thailand, Myanmar and Malaysia, J. Geol. Soc., 161, 799-812, doi:10.1144/0016-764903-124.

Morley, C. K. (2007), Variations in Late Cenozoic-Recent strike-slip and oblique-extensional geometries, within Indochina: The influence of pre-existing fabrics, J. Struct. Geol., 29, 36-58, doi:10.1016/j. jsg.2006.07.003

Murphy, M. A., and P. Copeland (2005), Transtensional deformation in the central Himalaya and its role in accommodating growth of the Himalayan orogen, Tectonics, 24, TC4012, doi:10.1029/2004TC001659.

Murphy, M. A., and A. Yin (2003), Structural evolution and sequence of thrusting in the Tethyan fold-thrust belt and Indus-Yalu suture zone, southwest Tibet, Geol. Soc. Am. Bull., 115, 21-34, doi:10.1130/00167606(2003)115<0021:SEASOT>2.0.CO;2.

Murphy, M. A., A. Yin, T. M. Harrison, S. B. Durr, Z. Chen, F. J. Ryerson, W. S. F. Kidd, X. Wang, and X. Zhou (1997), Did the Indo-Asian collision alone create the Tibetan Plateau?, Geology, 25, 719-722, doi:10.1130/0091-7613(1997)025<0719:DTIACA>2.3.CO;2

Murphy, M. A., A. Yin, P. Kapp, T. M. Harrison, L. Ding, and G. Jinghui (2000), Southward propagation of the Karakoram fault system, southwest Tibet: Timing and magnitude of slip, Geology, 28, 451-454, doi:10.1130/0091-7613(2000)28<451:SPOTKF>2.0.CO;2.

Murphy, M. A., A. Yin, P. Kapp, T. M. Harrison, C. E. Manning, F. J. Ryerson, L. Ding, and J. Guo (2002), Structural evolution of the Gurla Mandhata detachment system, southwest Tibet: Implications for the eastward extent of the Karakoram fault system, Geol. Soc. Am. Bull., 114 428-447, doi:10.1130/0016-7606(2002)114<0428:SEOTGM>2.0.CO;2. Murphy, M. A., J. E. Saylor, and L. Ding (2009), Late Miocene topographic inversion in southwest Tibet based on integrated paleoelevation reconstructions and structural history, Earth Planet. Sci. Lett., 282, 1-9, doi:10.1016/j.epsl.2009.01.006.

Nábělek, J., et al. (2009), Underplating in the Himalaya-Tibet collision zone revealed by the Hi-CLIMB experiment, Science, 325, 1371-1374 doi:10.1126/science. 1167719

Najman, Y., et al. (2010), Timing of India-Asia collision: Geological, biostratigraphic, and palaeomagnetic constraints, J. Geophys. Res., 115 B12416, doi:10.1029/2010JB007673.

Negredo, A. M., A. Replumaz, A. Villasenor, and S. Guillot (2007), Modeling the evolution of continental subduction processes in the PamirHindu Kush region, Earth Planet. Sci. Lett., 259, 212-225, doi:10.1016/j.epsl.2007.04.043.

Nikolaev, A. V., I. A. Sanina, V. G. Trifonov, and G. A. Vostrikov (1985), Structure and evolution of the Pamir-Hindu Kush region lithosphere, Phys. Earth Planet. Inter., 41, 199-206, doi:10.1016/0031-9201(85) 90034-2.

O'Neill, C., D. Muller, and B. Steinberger (2005), On the uncertainties in hot spot reconstructions and the significance of moving hot spot reference frames, Geochem. Geophys., Geosyst., 6, Q04003, doi:10.01029/ 2004GC000784.

Otofuji, Y.-i., Y. Inoue, S. Funahara, F. Murata, and X. Zheng (1990), Palaeomagnetic study of eastern Tibet: Deformation of the Three Rivers region, Geophys. J. Int., 103, 85-94, doi:10.1111/j.1365-246X.1990. tb01754.x.

Patriat, P., and J. Achache (1984), India-Asia collision chronology and its implications for crustal shortening and driving mechanisms, Nature, 311 615-621, doi:10.1038/311615a0.

Patzelt, A., H. Li, J. Wang, and E. Appel (1996), Palaeomagnetism of Cretaceous to Tertiary sediments from southern Tibet: Evidence for the extent of the northern margin of India prior to the collision with Eurasia, Tectonophysics, 259, 259-284, doi:10.1016/0040-1951(95)00181-6.

Pavlis, G. L., and S. Das (2000), The Pamir-Hindu Kush seismic zone as a strain marker for flow in the upper mantle, Tectonics, 19, 103-115, doi:10.1029/1999TC900062.

Pegler, G., and S. Das (1998), An enhanced image of the Pamir-Hindu Kush seismic zone from relocated earthquake hypocentres, Geophys. J. Int., 134, 573-595, doi:10.1046/j.1365-246x.1998.00582.x.

Peltzer, G., and P. Tapponnier (1988), Formation and evolution of strikeslip faults, rifts, and basins during the India-Asia collision: An experimental approach, J. Geophys. Res., 93, 15,085-15,117, doi:10.1029/ JB093iB12p15085

Phillips, R. J., R. R. Parrish, and M. P. Searle (2004), Age constraints on ductile deformation and long-term slip rates along the Karakoram fault zone, Ladakh, Earth Planet. Sci. Lett., 226, 305-319, doi:10.1016/j. eps1.2004.07.037.

Pubellier, M. (2008), Structural map of eastern Eurasia, Comm. for the Geol. Map of the World, Paris.

Pullen, A., P. Kapp, G. E. Gehrels, J. D. Vervoort, and L. Ding (2008), Triassic continental subduction in central Tibet and Mediterranean-style clo- 
sure of the Paleo-Tethys Ocean, Geology, 36, 351-354, doi:10.1130/ G24435A.1.

Pullen, A., P. Kapp, G. E. Gehrels, L. Ding, and Q. H. Zhang (2011), Metamorphic rocks in central Tibet: Lateral variations and implications for crustal structure, Geol. Soc. Am. Bull., 123, 585-600, doi:10.1130/ B30154.1.

Raterman, N. S., E. Cowgill, and L. Ding (2007), Variable structural style along the Karakoram fault explained using triple-junction analysis of intersecting faults, Geosphere, 3, 71-85.

Ratschbacher, L., B. R. Hacker, A. Calvert, L. E. Webb, J. C. Grimmer, M. O. McWilliams, T. Ireland, S. Dong, and J. Hu (2003), Tectonics of the Qinling (Central China): Tectonostratigraphy, geochronology, and deformation history, Tectonophysics, 366, 1-53, doi:10.1016/S00401951(03)00053-2.

Ratschbacher, L., I. Krumrei, M. Blumenwitz, M. Staiger, R. Gloaguen, B. V. Miller, S. D. Samson, M. A. Edwards, and E. Appel (2011), Rifting and strike-slip shear in central Tibet and the geometry, age and kinematics of upper crustal extension in Tibet, Geol. Soc. Spec. Publ., 353, 127-163, doi:10.1144/SP353.8

Replumaz, A., and P. Tapponnier (2003), Reconstruction of the deformed collision zone Between India and Asia by backward motion of lithospheric blocks, J. Geophys. Res., 108(B6), 2285, doi:10.1029/ 2001JB000661.

Replumaz, A., R. Lacassin, P. Tapponnier, and P. H. Leloup (2001), Large river offsets and Plio-Quaternary dextral slip rate on the Red River fault (Yunnan, China), J. Geophys. Res., 106, 819-836, doi:10.1029/ 2000JB900135

Replumaz, A., A. M. Negredo, A. Villasenor, and S. Guillot (2010), Indian continental subduction and slab break-off during Tertiary collision, Terra Nova, 22, 290-296.

Rezaei-Kahkhaei, M., A. Kananian, D. Esmaeily, and A. Asiabanha (2010), Geochemistry of the Zargoli granite: Implications for development of the Sistan Suture Zone, southeastern Iran, Isl. Arc, 19, 259-276, doi:10.1111/ j.1440-1738.2009.00704.x.

Richter, B., and M. Fuller (1996), Palaeomagnetism of the Sibumasu and Indochina blocks: Implications for the extrusion tectonic model, Geol. Soc. Spec. Publ., 106, 203-224, doi:10.1144/GSL.SP.1996.106.01.13.

Richter, B., E. Schmidtke, M. Fuller, N. Harbury, and A. R. Sumsudin (1999), Paleomagnetism of Peninsular Malaysia, J. Asian Earth Sci., 17, 477-519, doi:10.1016/S1367-9120(99)00006-1.

Ritts, B. D., and U. Biffi (2000), Magnitude of post-Middle Jurassic (Bajocian) displacement on the central Altyn Tagh fault system, northwest China, Geol. Soc. Am. Bull., 112, 61-74, doi:10.1130/0016-7606(2000) $112<61$ :MOPJBD $>2.0 . \mathrm{CO} ; 2$

Robert, A., M. Pubellier, J. De Sigoyer, J. Vergne, A. Lahfid, R. Cattin, N. Findling, and J. Zhu (2010), Structural and thermal characters of the Longmen Shan (Sichuan, China), Tectonophysics, 491, 165-173, doi:10.1016/j.tecto.2010.03.018

Robinson, A. C. (2009), Geologic offsets across the northern Karakorum fault: Implications for its role and terrane correlations in the western Himalayan-Tibetan orogen, Earth Planet. Sci. Lett., 279, 123-130, doi:10.1016/j.epsl.2008.12.039.

Robinson, A. C., A. Yin, C. E. Manning, T. M. Harrison, S.-H. Zhang, and X.-F. Wang (2004), Tectonic evolution of the northeastern Pamir: Constraints from the northern portion of the Cenozoic Kongur Shan extensional system, western China, Geol. Soc. Am. Bull., 116, 953-973, doi:10.1130/B25375.1.

Robinson, A. C., A. Yin, C. E. Manning, T. M. Harrison, S. H. Zhang, and X. F. Wang (2007), Cenozoic evolution of the eastern Pamir: Implications for strain-accommodation mechanisms at the western end of the Himalayan-Tibetan orogen, Geol. Soc. Am. Bull., 119, 882-896, doi:10.1130/B25981.1.

Robinson, D. M., P. G. DeCelles, and P. Copeland (2006), Tectonic evolution of the Himalayan thrust belt in western Nepal: Implications for channel flow models, Geol. Soc. Am. Bull., 118, 865-885, doi:10.1130/ B25911.1.

Roger, F., S. Calassou, J. Lacelot, J. Malavieille, M. Mattauer, Z. Xu, Z. Hao, and H. Liwei (1995), Miocene emplacement and deformation of the Konga Shan granite (Xianshui He fault zone, west Sichuan, China): Geodynamic implications, Earth Planet. Sci. Lett., 130, 201-216, doi:10.1016/0012-821X(94)00252-T.

Roger, F., M. Jolivet, and J. Malavieille (2008), Tectonic evolution of the Triassic fold belts of Tibet, C. R. Geosci., 340, 180-189.

Roger, F., L. Jolivet, and J. Malavieille (2010), The tectonic evolution of the Songpan-Garzê (north Tibet) and adjacent areas from Proterozoic to Present: A synthesis, J. Asian Earth Sci., 39, 254-269, doi:10.1016/ j.jseaes.2010.03.008.

Rolland, Y., G. Maheo, A. Pecher, and I. M. Villa (2009), Syn-kinematic emplacement of the Pangong metamorphic and magmatic complex along the Karakoram Fault (N Ladakh), J. Asian Earth Sci., 34, 10-25, doi:10.1016/j.jseaes.2008.03.009.

Royden, L. H., B. C. Burchfiel, and R. D. Van der Hilst (2008), The geological evolution of the Tibetan Plateau, Science, 321, 1054-1058, doi:10.1126/science. 1155371

San'kov, V., J. Déverchère, Y. Gaudemer, F. Houdry, and A. Filippov (2000), Geometry and rate of faulting in the North Baikal Rift, Siberia, Tectonics, 19, 707-722, doi:10.1029/2000TC900012.

Sato, K., Y. Liu, Z. Zhu, Z. Yang, and Y.-i. Otofuji (1999), Paleomagnetic study of middle Cretaceous rocks from Yunlong, western Yunnan, China: Evidence of southward displacement of Indochina, Earth Planet. Sci. Lett., 165, 1-15, doi:10.1016/S0012-821X(98)00257-X.

Sato, K., Y. Liu, Z. Zhu, Z. Yang, and Y.-i. Otofuji (2001), Tertiary paleomagnetic data from northwestern Yunnan, China: Further evidence for large clockwise rotation of the Indochina block and its tectonic implications, Earth Planet. Sci. Lett., 185, 185-198, doi:10.1016/S0012-821X (00)00377-0.

Sato, K., Y. Liu, Y. Wang, M. Yokoyama, S. y. Yoshioka, Z. Yang, and Y.-i. Otofuji (2007), Paleomagnetic study of Cretaceous rocks from Pu'er, western Yunnan, China: Evidence of internal deformation of the Indochina block, Earth Planet. Sci. Lett., 258, 1-15, doi:10.1016/j. eps1.2007.02.043.

Saylor, J., P. G. DeCelles, G. E. Gehrels, M. A. Murphy, R. Zhang, and P. Kapp (2010), Basin formation in the High Himalaya by arc-parallel extension and tectonic damming: Zhada basin, southwestern Tibet, Tectonics, 29, TC1004, doi:10.1029/2008TC002390.

Schill, E., E. Appel, O. Zeh, V. K. Singh, and P. Gautam (2001), Coupling of late-orogenic tectonics and secondary pyrrhotite remanences: Towards a separation of different rotation processes and quantification of rotational underthrusting in the western Himalaya (northern India), Tectonophysics, 337, 1-21, doi:10.1016/S0040-1951(01)00113-5.

Schlüter, H. U., C. Gaedicke, H. A. Roeser, B. Schreckenberger, H. Meyer, C. Reichert, Y. Djajadihardja, and A. Prexl (2002), Tectonic features of the southern Sumatra-western Java forearc of Indonesia, Tectonics, 21(5), 1047, doi:10.1029/2001TC901048.

Schoenbohm, L. M., B. C. Burchfiel, L. Chen, and J. Yin (2006a), Miocene to present activity along the Red River fault, China, in the context of continental extrusion, upper-crustal rotation, and lower-crustal flow, Geol. Soc. Am. Bull., 118, 672-688, doi:10.1130/B25816.1.

Schoenbohm, L. M., B. C. Burchfiel, and L. Cheng (2006b), Propagation of surface uplift, lower crustal flow, and Cenozoic tectonics of the southeast margin of the Tibetan Plateau, Geology, 34, 813-816, doi:10.1130/ G22679.1.

Schwab, M., et al. (2004), Assembly of the Pamirs: Age and origin of magmatic belts from the southern Tien Shan to the southern Pamirs and their relation to Tibet, Tectonics, 23, TC4002, doi:10.1029/2003TC001583.

Searle, M. P. (1996), Geological evidence against large-scale pre-Holocene offsets along the Karakoram Fault: Implications for the limited extrusion of the Tibetan Plateau, Tectonics, 15, 171-186, doi:10.1029/ 95TC01693.

Searle, M. P. (2006), Role of the Red River sear zone, Yunnan and Vietnam, in the continental extrusion of SE Asia, J. Geol. Soc. 163, 1025-1036, doi:10.1144/0016-76492005-144.

Searle, M. P. (2010), Structural constraints on the timing of left-lateral shear along the Red River shear zone in the Ailao Shan and Diancang Shan Ranges, Yunnan, SW China, Geosphere, 6, 316-338, doi:10.1130/ GES00580.1.

Searle, M. P., and R. J. Phillips (2007), Relationships between right-lateral shear along the Karakoram fault and metamorphism, magmatism, exhumation and uplift: Evidence from the K2-Gasherbrum-Pangong ranges, north Pakistan and Ladakh, J. Geol. Soc., 164, 439-450, doi:10.1144/ 0016-76492006-072.

Searle, M. P., and P. J. Treloar (2010), Was Late Cretaceous-Paleocene obduction of ophiolite complexes the primary cause of crustal thickening and regional metamorphism in the Pakistan Himalaya?, Geol. Soc. Spec. Publ., 338, 345-359, doi:10.1144/SP338.16.

Searle, M. P., R. I. Corfield, B. Stephenson, and J. McCarron (1997), Structure of the north Indian continental margin in the Ladakh-Zanskar Himalayas: Implications for the timing of obduction of the Spontang ophiolite, India-Asia collision and deformation events in the Himalaya, Geol. Mag., 134, 297-316, doi:10.1017/S0016756897006857.

Searle, M. P., S. R. Noble, J. M. Cottle, D. J. Waters, A. H. G. Mitchell, T. Hlaing, and M. S. A. Horstwood (2007), Tectonic evolution of the Mogok metamorphic belt, Burma (Myanmar) constrained by U-Th- $\mathrm{Pb}$ dating of metamorphic and magmatic rocks, Tectonics, 26, TC3014, doi:10.1029/2006TC002083

Searle, M. P., R. R. Parrish, A. V. Thow, S. R. Noble, R. J. Philips, and D. J. Waters (2010), Anatomy, age and evolution of a collisional mountain belt: The Baltoro granite batholith and Karakoram Metamorphic 
Complex, Pakistani Karakoram, J. Geol. Soc., 167, 183-202, doi:10.1144/0016-76492009-043.

Șengör, A. M. C. (1987), Tectonics of the Tethysides: Orogenic collage development in a collisional setting, Annu. Rev. Earth Planet. Sci., 15, 213-244, doi:10.1146/annurev.ea.15.050187.001241.

Șengör, A. M. C., and B. A. Natal'in (1996), Paleotectonics of Asia: Fragments of a synthesis, in The Tectonic Evolution of Asia, edited by A. Yin and T. M. Harrison, pp. 486-641, Cambridge Univ. Press, New York.

Şengör, A. M. C., B. A. Natal'in, and V. S. Burtman (1993), Evolution of the Altaid tectonic collage and Palaeozoic crustal growth in Eurasia, Nature, 364, 299-307, doi:10.1038/364299a0.

Shen, F., L. H. Royden, and B. C. Burchfiel (2001), Large-scale crustal deformation of the Tibetan Plateau, J. Geophys. Res., 106, 6793-6816, doi:10.1029/2000JB900389.

Shi, G.-H., N. Jiang, Y. Liu, Z.-Y. Zhang, and Y.-J. Xu (2009), Zircon Hf isotope signature of the depleted mantle in the Myanmar jadeitite: Implications for Mesozoic intra-oceanic subduction between the Eastern Indian Plate and the Burmese Platelet, Lithos, 112, 342-350, doi:10.1016/j.lithos.2009.03.011.

Skobolev, S. F. (1977), Horizontal compression and development of folds in the Peter the First range (in Russian), Geotektonika, 2, 105-119.

Smith, A. B., and J. Xu (1988), Palaeontology of the 1985 Tibet Geotraverse, Lhasa to Golmud, Philos. Trans. R. Soc. London, Ser. A, 327 53-105, doi:10.1098/rsta.1988.0122.

Smith, M., S. Chantraprasert, C. K. Morley, and I. Cartwright (2007) Structural geometry and timing of deformation in the Chainat duplex, Thailand, Geol. Soc. Spec. Publ., 290, 305-323, doi:10.1144/SP290.11.

Sobel, E. R., and T. A. Dumitru (1997), Thrusting and exhumation around the margins of the western Tarim basin during the India-Asia collision, J. Geophys. Res., 102, 5043-5063, doi:10.1029/96JB03267.

Sobel, E. R., J. Chen, and R. V. Heermance (2006), Late Oligocene-early Miocene initiation of shortening in the Southwestern Chinese Tian Shan Implications for Neogene shortening rate variations, Earth Planet. Sci. Lett., 247, 70-81, doi:10.1016/j.epsl.2006.03.048.

Socquet, A., and M. Pubellier (2005), Cenozoic deformation in western Yunnan (China-Myanmar border), J. Asian Earth Sci., 24, 495-515, doi:10.1016/j.jseaes.2004.03.006.

Sol, S., et al. (2007), Geodynamics of the southeastern Tibetan Plateau from seismic anisotropy and geodesy, Geology, 35, 563-566, doi:10.1130/G23408A.1.

Spurlin, M. S., A. Yin, B. K. Horton, J. Zhou, and J. Wang (2005), Structural evolution of the Yushu-Nangqian region and its relationship to syncollisional igneous activity, east-central Tibet, Geol. Soc. Am. Bull., 117 1293-1317, doi:10.1130/B25572.1.

Steinberger, B., and T. H. Torsvik (2008), Absolute plate motions and true polar wander in the absence of hotspot tracks, Nature, 452, 620-623, doi:10.1038/nature06824

Strecker, M. R., W. Frisch, M. W. Hamburger, L. Ratschbacher, A. Zamoruyev, and N. Sturchio (1995), Quaternary deformation in the Eastern Pamirs, Tadzhikistan and Kyrgyzstan, Tectonics, 14, 1061-1079, doi:10.1029/95TC00927.

Streule, M. J., R. J. Phillips, M. P. Searle, D. J. Waters, and M. S. A Horstwood (2009), Evolution and chronology of the Pangong Metamorphic Complex adjacent to the Karakoram Fault, Ladakh: Constraints from thermobarometry, metamorphic modelling and $\mathrm{U}-\mathrm{Pb}$ geochronology, J. Geol. Soc., 166, 919-932, doi:10.1144/0016-76492008-117.

Sun, J., and Z. Zhang (2009), Syntectonic growth strata and implications for late Cenozoic tectonic uplift in the northern Tian Shan, China, Tectonophysics, 463, 60-68, doi:10.1016/j.tecto.2008.09.008.

Takemoto, K., N. Halim, Y.-i. Otofuji, T. Van Tri, L. Van De, and S. Hada (2005), New paleomagnetic constraints on the extrusion of Indochina: Late Cretaceous results from the Song Da terrane, northern Vietnam, Earth Planet. Sci. Lett., 229, 273-285, doi:10.1016/j.epsl.2004.09.040.

Takemoto, K., et al. (2009), Tectonic deformation of the Indochina Peninsula recorded in the Mesozoic palaeomagnetic results, Geophys. J. Int. 179, 97-111, doi:10.1111/j.1365-246X.2009.04274.x.

Tan, X., and K. P. Kodama (2002), Magnetic anisotropy and paleomagnetic inclination shallowing in red beds: Evidence from the Mississippian Mauch Chunk Formation, Pennsylvania, J. Geophys. Res., 107(B11), 2311, doi:10.1029/2001JB001636.

Tan, X., S. Gilder, K. P. Kodama, W. Jiang, Y. Han, H. Zhang, H. Xu, and D. Zhou (2010), New paleomagnetic results from the Lhasa block: Revised estimation of latitudinal shortening across Tibet and implications for dating the India-Asia collision, Earth Planet. Sci. Lett., 293, 396-404, doi:10.1016/j.epsl.2010.03.013.

Tanaka, K., et al. (2008), Tectonic deformation around the eastern Himalayan syntaxis: Constraints from the Cretaceous palaeomagnetic data of the Shan-Thai Block, Geophys. J. Int., 175, 713-728, doi:10.1111/j.1365246X.2008.03885.x.
Tapponnier, P., M. Mattauer, J.-N. Proust, and C. Cassaigneau (1981), Mesozoic ophiolites, sutures, and arge-scale tectonic movements in Afghanistan, Earth Planet. Sci. Lett., 52, 355-371, doi:10.1016/0012821X(81)90189-8.

Tapponnier, P., G. Peltzer, and R. Armijo (1986), On the mechanics of the collision between India and Asia, Geol. Soc. Spec. Publ., 19, 113-157, doi:10.1144/GSL.SP.1986.019.01.07.

Tapponnier, P., et al. (1990), Active thrusting and folding in the Qilian Shan, and decoupling between upper crust and mantle in northeastern Tibet, Earth Planet. Sci. Lett., 97, 382-403, doi:10.1016/0012-821X (90)90053-Z.

Tapponnier, P., Z. Xu, F. Roger, B. Meyer, N. Arnaud, G. Wittlinger, and J. Yang (2001), Oblique stepwise rise and growth of the Tibet Plateau, Science, 294, 1671-1677, doi:10.1126/science.105978.

Tauxe, L. (2005), Inclination flattening and the geocentric axial dipole hypothesis, Earth Planet. Sci. Lett., 233, 247-261, doi:10.1016/j. eps1.2005.01.027.

Tauxe, L., K. P. Kodama, and D. V. Kent (2008), Testing corrections for paleomagnetic inclination error in sedimentary rocks: A comparative approach, Phys. Earth Planet. Inter., 169, 152-165, doi:10.1016/j. pepi.2008.05.006.

Taylor, M., A. Yin, F. J. Ryerson, P. Kapp, and L. Ding (2003), Conjugate strike-slip faulting along the Bangong-Nujiang suture zone accommodates coeval east-west extension and north-south shortening in the interior of the Tibetan Plateau, Tectonics, 22(4), 1044, doi:10.1029/ 2002TC001361.

ten Brink, U. S., and M. H. Taylor (2002), Crustal structure of central Lake Baikal: Insights into intracontinental rifting, J. Geophys. Res., 107(B7), 2132, doi:10.1029/2001JB000300.

Thomas, J.-C., H. Perroud, P. R. Cobbold, M. L. Bazhenov, V. S. Burtman, A. Chauvin, and E. Sadybakasov (1993), A paleomagnetic study of Tertiary formations from the Kyrgyz Tien-Shan and its tectonic Implications, J. Geophys. Res., 98, 9571-9589, doi:10.1029/92JB02912.

Thomas, J.-C., A. Chauvin, D. Gapais, M. L. Bazhenov, H. Perroud, P. R. Cobbold, and V. S. Burtman (1994), Paleomagnetic evidence for Cenozoic block rotations in the Tadjik depression (Central Asia), J. Geophys. Res., 99, 15,141-15,160, doi:10.1029/94JB00901.

Tjia, H. D., and K. K. Liew (1996), Changes in tectonic stress field in northern Sunda Shelf basins, Geol. Soc. Spec. Publ., 106, 291-306, doi:10.1144/GSL.SP.1996.106.01.19.

Torsvik, T. H., and L. R. M. Cocks (2009), The Lower Palaeozoic palaeogeographical evolution of the northeastern and eastern periGondwanan margin from Turkey to New Zealand, Geol. Soc. Spec. Publ., 325, 3-21, doi:10.1144/SP325.2.

Torsvik, T. H., R. D. Müller, R. Van der Voo, B. Steinberger, and C. Gaina (2008), Global plate motion frames: Toward a unified model, Rev. Geophys., 46, RG3004, doi:10.1029/2007RG000227.

Trifonov, V. G., I. A. Makarov, and S. F. Skobolev (1992), The TalasFergana active right-lateral fault, Ann. Tectonicae, 6, 224-237.

Valli, F., N. Arnaud, P. H. Leloup, E. R. Sobel, G. Mahéo, R. Lacassin, S. Guillot, H. Li, P. Tapponnier, and Z. Xu (2007), Twenty million years of continuous deformation along the Karakorum fault, western Tibet: A thermochronological analysis, Tectonics, 26, TC4004, doi:10.1029/ 2005 TC001913

Valli, F., et al. (2008), New U-Th/Pb constraints on timing of shearing and long-term slip-rate on the Karakorum fault, Tectonics, 27, TC5007, doi:10.1029/2007TC002184

van der Meer, D. G., W. Spakman, D. J. J. van Hinsbergen, M. L. Amaru, and T. H. Torsvik (2010), Toward absolute plate motions constrained by lower mantle slab remnants, Nat. Geosci., 3, 36-40, doi:10.1038/ ngeo 708 .

Van der Voo, R., W. Spakman, and H. Bijwaard (1999a), Tethyan slabs under India, Earth Planet. Sci. Lett., 171, 7-20, doi:10.1016/S0012821X(99)00131-4.

Van der Voo, R., W. Spakman, and H. Bijwaard (1999b), Mesozoic subducted slabs under Siberia, Nature, 397, 246-249, doi:10.1038/16686.

Van der Woerd, J., F. J. Ryerson, P. Tapponnier, A.-S. Meriaux, Y. Gaudemer, B. Meyer, R. C. Finkel, M. Caffee, G. Zhao, and Z. Xu (2000), Uniform slip-rate along the Kunlun Fault: Implications for seismic behaviour and large-scale tectonics, Geophys. Res. Lett., 27, 2353-2356, doi:10.1029/1999GL011292

Van der Woerd, J., P. Tapponnier, F. J. Ryerson, A.-S. Meriaux, B. Meyer, Y. Gaudemer, R. C. Finkel, M. W. Caffee, G. Zhao, and Z. Xu (2002), Uniform postglacial slip-rate along the central $600 \mathrm{~km}$ of the Kunlun Fault (Tibet), from ${ }^{26} \mathrm{Al},{ }^{10} \mathrm{Be}$, and ${ }^{14} \mathrm{C}$ dating of riser offsets, and climatic origin of the regional morphology, Geophys. J. Int., 148, 356-388, doi:10.1046/j.1365-246x.2002.01556.x.

van Hinsbergen, D. J. J., G. B. Straathof, K. F. Kuiper, W. D. Cunningham, and J. R. Wijbrans (2008), No rotations during transpressional orogeny in 
the Gobi Altai: Coinciding Mongolian and Eurasian apparent polar wander paths, Geophys. J. Int., 173, 105-126, doi:10.1111/j.1365246X.2007.03712.x.

van Hinsbergen, D. J. J., B. Steinberger, P. V. Doubrovine, and R. Gassmöller (2011), Acceleration and deceleration of India-Asia convergence since the Cretaceous: Roles of mantle plumes and continental collision, J. Geophys. Res., 116, B06101, doi:10.1029/2010JB008051.

Vassallo, R., M. Jolivet, J.-F. Ritz, R. Braucher, C. Larroque, C. Sue, M. Todbileg, and D. Javkhlanbold (2007), Uplift age and rates of the Gurvan Bogd System (Gobi-Altay) by apatite fission track analysis, Earth Planet. Sci. Lett., 259, 333-346, doi:10.1016/j.eps1.2007.04.047.

Vigny, C., A. Socquet, C. Rangin, N. Chamot-Rooke, M. Pubellier, M.-N. Bouin, G. Bertrand, and M. Becker (2003), Present-day crustal deformation around Sagaing fault, Myanmar, J. Geophys. Res., 108(B11), 2533, doi:10.1029/2002JB001999.

Volkmer, J. E., P. Kapp, J. H. Guynn, and Q. Lai (2007), CretaceousTertiary structural evolution of the north central Lhasa terrane, Tibet, Tectonics, 26, TC6007, doi:10.1029/2005TC001832.

Wallis, S., T. Tsujimori, M. Aoya, T. Kaweakami, K. Terada, K. Suzuki, and H. Hyodo (2003), Cenozoic and Mesozoic metamorphism in the Longmenshan orogen: Implications for geodynamic models of eastern Tibet, Geology, 31, 745-748, doi:10.1130/G19562.1.

Wang, C., Z. Liu, H. Yi, S. Liu, and X. Zhao (2002), Tertiary crustal shortening and peneplenation in the Hoh Xil region: Implications for the tectonic history of the northern Tibetan Plateau, J. Asian Earth Sci., 20, 211-223, doi:10.1016/S1367-9120(01)00051-7.

Wang, C., X. Zhao, Z. Liu, P. C. Lippert, S. A. Graham, R. S. Coe, H. Yi, L. Zhu, S. Liu, and Y. Li (2008), Constraints on the early uplift history of the Tibetan Plateau, Proc. Natl. Acad. Sci. U. S. A., 105, 4987-4992, doi:10.1073/pnas.0703595105.

Wang, E., and B. C. Burchfiel (2000), Late Cenozoic to Holocene deformation in southwestern Sichuan and adjacent Yunnan, China, and its role in formation of the southeastern part of the Tibetan Plateau, Geol. Soc. Am. Bull., 112, 413-423, doi:10.1130/0016-7606(2000)112<413 LCTHDI $>2.0 . \mathrm{CO} ; 2$.

Wang, G., J. Wan, E. Wang, D. Zheng, and F. Li (2008), Late Cenozoic to recent transtensional deformation across the Southern part of the Gaoligong shear zone between the Indian plate and SE margin of the Tibetan Plateau and its tectonic origin, Tectonophysics, 460, 1-20, doi:10.1016/j. tecto.2008.04.007.

Wang, J., C. Bao, Z. Lou, and Z. Guo (1989), Formation and development of the Sichuan Basin, in Sedimentary Basins of the World, vol. 1, Chinese Sedimentary Basins, edited by X. Zhu, pp. 147-163, Elsevier, Amsterdam.

Wang, J., X. Hu, L. F. Jansa, and Z. Huang (2011), Provenance of the upper Cretaceous-Eocene deep-water sandstones in Sangdanlin, southern Tibet: Constraints on the timing of initial India-Asia collision, J. Geol., 119, 293-309, doi:10.1086/659145.

Wang, L.-L., J. C. Aitchison, C.-H. Lo, and Q.-G. Zeng (2008), Geochemistry and geochronology of the amphibolite blocks in ophiolitic melanges along Bangong-Nujiang suture, central Tibet, J. Asian Earth Sci., 33 , 122-138, doi:10.1016/j.jseaes.2007.10.022.

Wang, P.-L., C.-H. Lo, S.-L. Chung, T.-Y. Lee, C.-Y. Lan, and T. V. Thang (2000), Onset timing of left-lateral movement along the Ailao Shan-Red River Shear Zone: ${ }^{40} \mathrm{Ar} /{ }^{39} \mathrm{Ar}$ dating constraint from the Nam Dinh area, northeastern Vietnam, J. Asian Earth Sci., 18, 281-292, doi:10.1016/S1367-9120(99)00064-4.

Wang, S., X. Fang, Q. Lai, D. Zheng, and Y. Wang (2009), New radiometric dating constrains the time for initiation of the Karakorum fault zone (KFZ), SW Tibet, Tectonophysics, 475, 503-513, doi:10.1016/j. tecto.2009.06.016.

Wang, Y.-J., W.-M. Fan, Y. Zhang, T. Peng, X. Chen, and Y. Xu (2006), Kinematics and ${ }^{40} \mathrm{Ar} /{ }^{39} \mathrm{Ar}$ geochronology of the Gaoligong and Chongshan shear systems, western Yunnan, China: Implications for early Oligocene tectonic extrusion of SE Asia, Tectonophysics, 418, 235-254, doi:10.1016/j.tecto.2006.02.005

Willett, S., and C. Beaumont (1994), Subduction of Asian lithospheric mantle beneath Tibet inferred from models of continental collision, Nature, 369, 642-645, doi:10.1038/369642a0.

Wilson, C. J. L., M. J. Harrowfield, and A. J. Reid (2006), Brittle modification of Triassic architecture in eastern Tibet: Implications for the construction of the Cenozoic plateau, J. Asian Earth Sci., 27, 341-357, doi:10.1016/j.jseaes.2005.04.004.

Wittlinger, G., P. Tapponnier, G. Poupinet, J. Mei, D. Shi, G. Herquel, and F. Masson (1998), Tomographic evidence for localized lithospheric shear along the Altyn Tagh fault, Science, 282, 74-76, doi:10.1126/science. 282.5386.74.

Wu, Z. H., P. J. Barosh, Z. H. Wu, D.-G. Hu, X. Zhao, and P. Ye (2008), Vast early Miocene lakes of the central Tibetan Plateau, Geol. Soc. Am. Bull., 120, 1326-1337, doi:10.1130/B26043.1.
Yamashita, I., A. Surinkum, Y. Wada, M. Fujihara, M. Yokoyama, H. Zaman, and Y.-i. Otofuji (2011), Paleomagnetism of the Middle-Late Jurassic to Cretaceous red beds from the peninsular Thailand: Implications for collision tectonics, J. Asian Earth Sci., 40, 784-796, doi:10.1016/j.jseaes.2010.11.001

Yang, Y., and M. Liu (2002), Cenozoic deformation of the Tarim plate and the implications for mountain building in the Tibetan Plateau and the Tian Shan, Tectonics, 21(6), 1059, doi:10.1029/2001TC001300.

Yang, Z., and J. Besse (1993), Paleomagnetic study of Permian and Mesozoic sedimentary rocks from Northern Thailand supports the extrusion model for Indochina, Earth Planet. Sci. Lett., 117, 525-552, doi:10.1016/0012-821X(93)90101-E.

Yang, Z., J. Yin, Z. Sun, Y.-i. Otofuji, and K. Sato (2001), Discrepant Cretaceous paleomagnetic poles between eastern China and Indochina: A consequence of the extrusion of Indochina, Tectonophysics, 334, 101-113, doi:10.1016/S0040-1951(01)00061-0.

Yang, Z. Y., J. Besse, V. Sutheetorn, J. P. Bassoullet, H. Fontaine, and E. Buffetaut (1995), Lower-Middle Jurassic paleomagnetic data from the Mae Sot area (Thailand): Paleogeographic evolution and deformation history of Southeastern Asia, Earth Planet. Sci. Lett., 136, 325-341, doi:10.1016/0012-821X(95)00192-F

Yin, A., and T. M. Harrison (2000), Geologic evolution of the HimalayanTibetan orogen, Annu. Rev. Earth Planet. Sci., 28, 211-280, doi:10.1146/ annurev.earth.28.1.211.

Yin, A., and S. Nie (1993), An indentation model for the north and south China collision and the development of the Tan-Lu and Honam fault systems, eastern Asia, Tectonics, 12, 801-813, doi:10.1029/93TC00313.

Yin, A., T. M. Harrison, F. J. Ryerson, W.-J. Chen, W. S. F. Kidd, and P. Copeland (1994), Tertiary structural evolution of the Gangdese thrust system, southeastern Tibet, J. Geophys. Res., 99, 18,175-18,201, doi:10.1029/94JB00504.

Yin, A., S. Nie, P. Craig, T. M. Harrison, F. J. Ryerson, Q. Xianglin, and Y. Geng (1998), Late Cenozoic tectonic evolution of the southern Chinese Tian Shan, Tectonics, 17, 1-27, doi:10.1029/97TC03140.

Yin, A. T. M. Harrison, M. A. Murphy, M. Grove, S.-Y. Nie, F. J. Ryerson, W. X. Feng, and C. Z. Le (1999a), Tertiary deformation history of southeastern and southwestern Tibet during the Indo-Asia collision, Geol. Soc. Am. Bull., 111, 1644-1664, doi:10.1130/0016-7606(1999)111<1644: TDHOSA $>2.3 . \mathrm{CO} ; 2$

Yin, A., P. A. Kapp, M. A. Murphy, C. E. Manning, M. Harrison, M. Grove, L. Ding, X.-G. Deng, and C.-M. Wu (1999b), Significant late Neogene east-west extension in northern Tibet, Geology, 27, 787-790, doi:10.1130/0091-7613(1999)027<0787:SLNEWE $>2.3 . C O ; 2$

Yin, A., Y. Dang, M. Zhang, M. W. McRivette, W. P. Burgess, and $X$. Chen (2007), Cenozoic tectonic evolution of Qaidam basin and its surrounding regions (part 2): Wedge tectonics in southern Qaidam basin and the Eastern Kunlun Range, Spec. Pap. Geol. Soc. Am., 433, 369-390.

Yin, A., Y.-Q. Dang, L.-C. Wang, W. M. Jiang, S.-P. Zhou, X.-H. Chen, D. E. Gehrels, and M. W. McRivette (2008a), Cenozoic tectonic evolution of Qaidam basin and its surrounding regions (Part 1): The southern Qilian Shan-Nan Shan thrust belt and northern Qaidam basin, Geol. Soc. Am. Bull., 120, 813-846, doi:10.1130/B26180.1.

Yin, A., Y.-Q. Dang, M. Zhang, X.-H. Chen, and M. W. McRivette (2008b), Cenozoic tectonic evolution of Qaidam basin and its surrounding regions (Part 3): Structural geology, sedimentation, and regional tectonic reconstruction, Geol. Soc. Am. Bull., 120, 847-876, doi:10.1130/ B26232.1.

Yin, A., C. A. Dubey, T. K. Kelty, A. A. G. Webb, T. M. Harrison, C. Y. Chou, and J. Célérier (2010), Geologic correlation of the Himalayan orogen and Indian craton: Part 2. Structural geology, geochronology, and tectonic evolution of the Eastern Himalaya, Geol. Soc. Am. Bull., 122 , 360-395, doi:10.1130/B26461.1

Yoshioka, S., Y. Liu, K. Sato, H. Inokuchi, S. Li, H. Zaman, and Y.-i. Otofuji (2003), Paleomagnetic evidence for post-Cretaceous internal deformation of the Chuan Dian Fragment in the Yangtze block: A consequence of indentation of India into Asia, Tectonophysics, 376, 61-74, doi:10.1016/j.tecto.2003.08.010.

Yuan, W., A. Carter, J. Dong, Z. Bao, Y. An, and Z. Huo (2006), Mesozoic-Tertiary exhumation history of the Altai Mountains, northern Xinjiang, China: New constraints from apatite fission track data, Tectonophysics, 412, 183-193, doi:10.1016/j.tecto.2005.09.007.

Yue, Y., and J. G. Liou (1999), Two-stage evolution model for the Altyn Tagh fault, China, Geology, 27, 227-230, doi:10.1130/0091-7613(1999) 027<0227:TSEMFT $>2.3$.CO;2.

Yue, Y., B. D. Ritts, and S. A. Graham (2001), Initiation and long-term slip history of the Altyn Tagh Fault, Int. Geol. Rev., 43, 1087-1093, doi:10.1080/00206810109465062.

Yue, Y., B. D. Ritts, S. A. Graham, J. L. Wooden, G. E. Gehrels, and Z. Zhang (2004), Slowing extrusion tectonics: Lowered estimate of 
post-Early Miocene slip rate for the Altyn Tagh fault, Earth Planet. Sci. Lett., 217, 111-122, doi:10.1016/S0012-821X(03)00544-2.

Yue, Y., S. A. Graham, B. D. Ritts, and J. L. Wooden (2005), Detrital zircon provenance evidence for large-scale extrusion along the Altyn Tagh fault, Tectonophysics, 406, 165-178, doi:10.1016/j.tecto.2005.05.023.

Zaman, H., and M. Torii (1999), Palaeomagnetic study of Cretaceous red beds from the eastern Hindukush ranges, northern Pakistan: Palaeoreconstruction of the Kohistan-Karakoram composite unit before the India-Asia collision, Geophys. J. Int., 136, 719-738, doi:10.1046/ j.1365-246x.1999.00757.x.

Zhang, P., et al. (2004), Continuous deformation of the Tibetan Plateau from global positioning system data, Geology, 32, 809-812, doi:10.1130/G20554.1.

Zhang, Y. (2010), The early-middle Jurassic Gerze SSZ ophiolites and tectonic evolution of the Bangong suture, Tibet, Abstract T43A-2165 presented at 2010 Fall Meeting, AGU, San Francisco, Calif., 13-17 Dec.

Zhang, Y., and J. Zheng (1994), Geologic Overview in Kokshili, Qinghai and Adjacent Areas, 177 pp., Seismol. Publ. House, Beijing.

Zhao, J., et al. (2010), The boundary between the Indian and Asian tectonic plates below Tibet, Proc. Natl. Acad. Sci. U. S. A., 107, 11,229-11,233, doi:10.1073/pnas.1001921107.

Zhao, X., and R. S. Coe (1987), Paleomagnetic constraints on the collision and rotation of north and south China, Nature, 327, 141-144, doi:10.1038/327141a0.

Zheng, D., P.-Z. Zhang, J. Wan, D. Yuan, L. Chuanyou, G. Yin, G. Zhang, Z. Wang, W. Min, and J. Chen (2006), Rapid exhumation at $\sim 8 \mathrm{Ma}$ on the Liupan Shan thrust fault from apatite fission-track thermochronology: Implications for growth of the northeastern Tibetan Plateau margin, Earth Planet. Sci. Lett., 248, 198-208, doi:10.1016/j.epsl.2006.05.023.

Zhou, D., and S. A. Graham (1996), Songpan-Ganzi complex of the west Qinling Shan as a Triassic remnant ocean basin, in The Tectonic Evolution of Asia, edited by A. Yin and T. M. Harrison, pp. 281-299, Cambridge Univ. Press, Cambridge, U. K.
Zhou, D., Z. Sun, H.-Z. Chen, C.-H. Xu, W.-Y. Wang, X. Pang, D.-S. Cai, and D.-K. Hu (2008), Mesozoic paleogeography and tectonic evolution of South China Sea and adjacent areas in the context of Tethyan and Paleo-Pacific interconnections, Isl. Arc, 17, 186-207, doi:10.1111/ j.1440-1738.2008.00611.x.

Zhou, J., F. Xu, T. Wang, A. Cao, and C. Yin (2006), Cenozoic deformation history of the Qaidam Basin, NW China: Results from cross-section restoration and implications for Qinghai-Tibet Plateau tectonics, Earth Planet. Sci. Lett., 243, 195-210, doi:10.1016/j.epsl.2005.11.033.

Zhu, B., W. S. F. Kidd, D. B. Rowley, B. S. Currie, and N. Shafique (2005), Age of initiation of the India-Asia collision in the east-central Himalaya, J. Geol., 113, 265-285, doi:10.1086/428805.

Zhu, D.-C., Z.-D. Zhao, Y. Niu, X. Mo, S.-L. Chung, Z. Hou, L.-Q. Wang, and F.-Y. Wu (2011), The Lhasa Terrane: Record of a microcontinent and its histories of drift and growth, Earth Planet. Sci. Lett., 301, 241-255, doi:10.1016/j.epsl.2010.11.005.

Zhuang, G. S., J. K. Hourigan, B. D. Ritts, and M. L. Kent-Corson (2011), Cenozoic multiple-phase tectonic evolution of the northern Tibetan Plateau: Constraints from sedimentary records from Qaidam Basin, Hexi Corridor, and Subei Basin, northwest China, Am. J. Sci., 311, 116-152, doi:10.2475/02.2011.02.

P. G. DeCelles and P. Kapp, Department of Geosciences, University of Arizona, 1040 E. 4th St., Tucson, AZ 85721, USA.

G. Dupont-Nivet, Géosciences Rennes, UMR-CNRS 6118, Université de Rennes 1, Campus de Beaulieu, F-35042 Rennes CEDEX, France.

P. C. Lippert, Department of Earth and Planetary Sciences, University of California, 1156 High St., Santa Cruz, CA 95064, USA.

T. H. Torsvik, Center for Geodynamics, Geological Survey of Norway, Leiv Eirikssons vei 39, PO Box 3006 Lade, NO-7491 Trondheim, Norway.

D. J. J. van Hinsbergen, Physics of Geological Processes, University of Oslo, Sem Sælands vei 24, NO-0316 Oslo, Norway. (d.v.hinsbergen@ fys.uio.no) 